Ariane de Oliveira Turati

\title{
ANÁLISE DO PERFIL DIÁRIO E DOS MECANISMOS DE SÍNTESE DA MELATONINA PINEAL EM RATOS DIABÉTICOS POR ESTREPTOZOTOCINA TRATADOS COM INSULINA
}

\begin{abstract}
Dissertação apresentada ao Programa de Pós-Graduação em Fisiologia Humana do Instituto de Ciências Biomédicas da Universidade de São Paulo, para obtenção do Título de Mestre em Ciências.
\end{abstract}




\section{ANÁLISE DO PERFIL DIÁRIO E DOS MECANISMOS DE SÍNTESE DA MELATONINA PINEAL EM RATOS DIABÉTICOS POR ESTREPTOZOTOCINA TRATADOS COM INSULINA}

Dissertação apresentada ao Programa de Pós-Graduação em Fisiologia Humana do Instituto de Ciências Biomédicas da Universidade de São Paulo, para obtenção do Título de Mestre em Ciências.

Área de Concentração: Fisiologia Humana

Orientador: Prof. Dr. José Cipolla Neto

Versão original

São Paulo

2013 
DADOS DE CATALOGAÇÃO NA PUBLICAÇÃO (CIP)

Serviço de Biblioteca e Informação Biomédica do

Instituto de Ciências Biomédicas da Universidade de São Paulo

reprodução não autorizada pelo autor

Turati, Ariane de Oliveira.

Análise do perfil diário e dos mecanismos de síntese da melatonina pineal em ratos diabéticos por estreptozotocina tratados com insulina / Ariane de Oliveira Turati. -- São Paulo, 2013.

Orientador: Prof. Dr. José Cipolla Neto.

Dissertação (Mestrado) - Universidade de São Paulo. Instituto de Ciências Biomédicas. Departamento de Fisiologia e Biofísica. Área de concentração: Fisiologia Humana. Linha de pesquisa:

Neuroendocrinologia.

Versão do título para o inglês: Pineal melatonin synthesis daily profile and mechanisms in streptozotocin diabetic rats treated with insulin.

1. Melatonina 2. Diabetes mellitus 3. Insulina 4. Hiperglicemia I. Cipolla Neto, Prof. Dr. José II. Universidade de São Paulo. Instituto de Ciências Biomédicas. Programa de Pós-Graduação em Fisiologia Humana III. Título. 
Candidato(a):

Título da Dissertação:

Orientador(a):
Ariane de Oliveira Turati.

Análise do perfil diário e dos mecanismos de sintese da melatonina pineal em ratos diabéticos por estreptozotocina tratados com insulina.

A Comissão Julgadora dos trabalhos de Defesa da Dissertação de Mestrado, em sessão pública realizada a considerou
( ) Aprovado(a)
( ) Reprovado(a)

Examinador(a): Assinatura:

Nome:

Instituição:

Examinador(a): Assinatura:

Nome:

Instituição:

Presidente: Assinatura:

Nome:

Instituição: 


\section{CerTIFICADO}

Certificamos que o protocolo registrado sob n 199 nas fls. 116 do livro 02 para uso de animais em experimentação, sob a responsabilidade do Prof(a) $\operatorname{Dr}(a)$ ) José Cipolla Neto, Coordenador (a) da Linha de pesquisa "O papel da melatonina no controle do metabolismo energético: ações centrais e a regulação circadiana da função metabólica" do qual participam o(s) aluno(s) Jéssica Andrade da Silva, Caroline Mendes, Rafael Maso Prévide, Ariane de Oliveira Turati, Angela Ramos Lobo, Rosana Fátima Dantas Ferreira, Ana Maria de Souza Lopes, Ronaldo Meira de Mello, Marco Taneda, Rafael Peres, Fernanda Gaspar do Amaral, Eliângela de Lima, Lia de Alencar Coelho,Daniella do Carmo Buonfiglio e os pesquisadores Fabio Bessa Lima, Silvana Bordin, Sara Schammah, Carla Roberta de Oliveira Carvalho, Solange Castro Afeche, Edson Amaro Jr., está de acordo com os Princípios Éticos de Experimentação Animal adotado pela Sociedade Brasileira de Ciência de Animais de Laboratório (SBCAL) e foi aprovado pela COMISSÃO DE ÉTICA NO USO DE ANIMAIS (CEUA) em 24.01.2012, com validade de 4 anos.

São Paulo, 27 de janeiro de 2012.

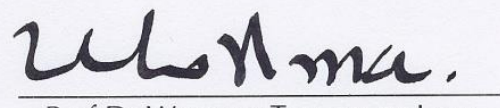

Prof.Dr.WOTHAN TAVARES DE LIMA

Coordenador

CEUA - ICB/USP

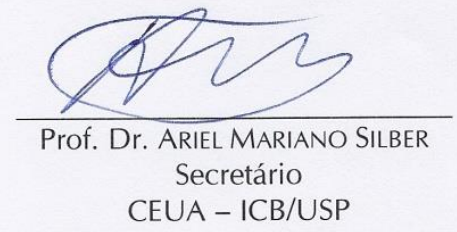


Dedico esse trabalho a todos que, assim como eu, encontraram na Ciência uma forma de entender um pouco sobre quem somos e sobre 0 que nos cerca, contribuindo, de forma singela, para a harmonia entre todas as formas de vida que habitam nosso mundo. 


\section{AGRADECIMENTOS}

Inicialmente, gostaria de agradecer à Universidade de São Paulo por oferecer a oportunidade de realização do presente trabalho. Em especial, agradeço ao pessoal do Instituto de Ciências Biomédicas, abrangendo toda equipe de professores e estudantes, assim como ao pessoal responsável pela manutenção da limpeza, do biotério e também da biblioteca, secretaria, e aos setores didático e de informática. Apenas com as adequadas condições de estrutura física e intelectual é que se torna possível obter uma rotina harmoniosa e, consequentemente, desenvolver os projetos aos quais nos dedicamos diariamente.

Agradeço, ainda, ao Conselho Nacional de Pesquisa e Desenvolvimento (CNPq) pelo apoio financeiro direto recebido ao longo do Mestrado e também à Fundação de Amparo à Pesquisa do Estado de São Paulo (FAPESP) pelo financiamento dos projetos desenvolvidos no Laboratório de Neurobiologia.

Meus agradecimentos também ao Laboratório de Farmacologia do Instituto Butantan, em especial a Solange Castro Afeche pelo auxílio na realização dos procedimentos de análise de atividade enzimática e cultura de pinealócitos, assim como ao Laboratório de Neurofarmacologia Molecular, em especial ao Professor Cristoforo Scavone e a Larissa de Sá Lima, pela disponibilidade em desenvolver o teste da atividade da $\mathrm{Na}^{+} / \mathrm{K}^{+}$ATPase para a glândula pineal. Agradeço também à Patrícia Rodrigues Lourenço Gomes pela grande ajuda nos ensaios de expressão proteica.

A partir de agora, me reservo ao direito de agradecer de maneira informal e pessoal a todos aqueles que fizeram grande diferença para minha formação durante essa etapa da pós-graduação percorrida, abrangendo ainda o breve período de iniciação científica que o antecedeu.

Primeiramente, agradeço imensamente ao Professor José Cipolla Neto, que não é professor apenas pelo título recebido, mas que realmente é um grande mentor, conforme todos nós podemos perceber pelo convívio diário. Agradeço a ele pela receptividade, ao me aceitar, no último ano da graduação, para o desenvolvimento do meu Trabalho de Conclusão de Curso. Desde essa época, e de forma mais intensa no Mestrado, tive a oportunidade de vivenciar não apenas o mundo das Neurociências, mas da Ciência de um modo geral, com um rigor e concepção que justificam a qualidade dos trabalhos realizados sob a sua 
supervisão. Cabe aqui ressaltar não apenas o lado profissional, mas também o lado pessoal do Professor, que tem por características marcantes a gentileza, generosidade e respeito ao jeito de ser de cada um de nós, permitindo a nossa evolução profissional e pessoal de acordo com o nosso próprio ritmo.

Agradeço à Fernanda Gaspar do Amaral, pelo seu apoio absolutamente constante desde o primeiro dia em que coloquei meus pés no laboratório. Naquela época eu não poderia prever a oportunidade de crescimento que me estava reservada pela vivência dia a dia com ela. É realmente impossível listar tudo o que aprendi ao longo desses anos, mas para que isso se faça mais claro gostaria de destacar a conduta profissional da Fernanda, cujo extremo cuidado em cada tarefa e projeto por ela conduzidos no laboratório me revelaram o que considero o perfil ideal de um pesquisador, ou melhor, de um verdadeiro cientista. Semelhante aspecto aliado à sua infinita paciência e boa vontade em compartilhar seu conhecimento com o pessoal do nosso laboratório e de outros ainda são características pouco vistas hoje em dia, mas que contribuem enormemente para o avançar das pesquisas e para que essas rendam resultados que farão, a longo prazo, a diferença para o bemestar humano. Como já se faz nítido pelo que foi dito acima, a convivência com a Fernanda não trouxe apenas crescimento científico, mas também moral. Espero poder seguir esse exemplo em minhas relações profissionais e pessoais.

Agradeço à Julieta Scialfa, com quem muito aprendi ao longo desses anos. Uma pessoa sempre disposta a ajudar aos demais, sem que essa ajuda ficasse restrita a questões profissionais apenas. Todos do laboratório sabem que a nossa rotina e os nossos experimentos que duram noites, semanas e meses seriam inviáveis sem o amparo, os cuidados e o trabalho incessante da Julieta. Todos do laboratório sabem também que a Julieta é, essencialmente, uma "mãezona", sempre ouvindo nossos problemas, fossem quais fossem, e contribuindo positivamente para a solução deles. Sou muito grata pelo auxílio que recebi dela para a realização dos meus experimentos, que demandavam um número elevado de animais, sempre adequadamente mantidos. Sou grata, ainda, pelas dicas e inúmeros conselhos que dela recebi. A generosidade, a disposição e a alegria são marcas registradas da Julieta, mais um exemplo a seguir que tive a oportunidade de conhecer no laboratório.

Dedico agora meus sinceros agradecimentos ao pessoal do Laboratório de Neurobiologia. Sem dúvidas tive a oportunidade de aprender com cada uma das 
pessoas com quem tive a oportunidade de conviver nesses últimos tempos. Assim, meu muito obrigada a todos que me deram diversas dicas, que me incentivaram quando algum receio resolvia aparecer, que seguraram os ratos para que eu injetasse a insulina, que compartilharam experiências, medos, protocolos, pizzas de madrugada e risadas. Sem dúvida alguma é impossível fazer Ciência sozinho e acredito que cada dia mais entendemos isso no laboratório. Agraço à Jéssica Andrade, companheira desde os tempos de faculdade, mas que apenas no Mestrado tive a oportunidade de conhecer melhor e descobrir muitas afinidades. Agradeço à Caroline Mendes que sempre me ajudou com os blocos experimentais de tratamento com insulina, autora de frases célebres no laboratório. Agradeço à Daniella, pela ajuda nos ensaios de AMPc na glândula pineal e em outras circunstâncias. Agradeço à Angela, com quem tive a oportunidade de partilhar as dificuldades de se tratar de ratos diabéticos. Agradeço à Rosana, com quem dividi um pouco do mundo da microdiálise. Agradeço ainda aos meninos do laboratório, com quem convivi menos, mas que sempre estiverem presentes no dia a dia do laboratório, auxiliando no que fosse necessário: Rodrigo Garcia, Rafael Peres, Rafael Prévide, Raphael Afonso de Matos, Eduardo Reis e Sinésio Júnior. Gostaria ainda de agradecer a Lia Coelho, Ana Lopes e Maria Alice.

Partindo agora para o agradecimento aos familiares, gostaria de agradecer primeiramente e infinitamente ao meu pai Oberdam e à minha mãe Sandra, pelo amor incondicional e apoio constante desde, literalmente, sempre. É realmente uma tarefa impossível expressar de forma fiel o que sinto ao pensar no carinho e dedicação com que fui criada e que sustentam o meu ser até hoje em qualquer caminho que eu opte por seguir em minha vida. Só tenho gratidão e amor para dedicar a eles nesse momento. Espero poder retribuir, a cada dia, todo o carinho recebido, refletindo em todas as circunstâncias da minha vida os ensinamentos que com eles aprendi. É claro que a família não seria completa sem as presenças da minha avó Amélia e dos meus primos, Lucimara, Márcio e Bruna. É deles também os exemplos que tiro para a formação do meu caráter e que, todos juntos, contribuem para a formação do meu lar. Meus agradecimentos e amor a todos, sempre!

Ainda, dedico meus agradecimentos e intenso carinho ao Théo Gremen, que me acompanha há 4 anos e tem grande parcela de contribuição para a minha formação, seja pessoal, seja científica, uma vez que nos encontramos unidos também pelo interesse pelo interesse pelas Ciências, sendo muito confortador poder 
compartilhar com ele minhas experiências, descobertas e pareceres nesse sentido. E é claro, graças a muito carinho e respeito pelo que escolhi é que tive a oportunidade de contar com sua ajuda nesses anos para virar inúmeros finais de semana me dedicando ao Mestrado no próprio laboratório e também em casa. Muito obrigada pela companhia, pelo apoio e por tolerar meus altos e baixos, tão comuns para quem decidi seguir pelo mundo da Biologia. Obrigada por repartir essa fase de crescimento profissional e pessoal pela qual passamos.

Agradeço também aos meus amigos da faculdade, claramente amigos para toda a vida, com que divido não apenas a formação, mas também problemas e alegrias. Muito obrigada à Priscila, Tatiana, Fernanda e Patrícia, companheiras constantes, e ainda à Lucila e Carla, com que vivenciei esses anos de Mestrado com todas as suas peculiaridades e dificuldades, que se tornaram mais suaves na medida em pudemos enfrentar isso juntas. Estendo meus agradecimentos aos demais amigos da 307, nossa turma de graduação, aqui representados pelas meninas.

Finalmente, faço aqui um agradecimento geral e sem dedicação exclusiva a alguém, mas igualmente importante. Agradeço à vida! A vida, que tive a oportunidade de estudar, de forma ainda muito discreta, nos domínios do organismo humano, me deparando com sua beleza e harmonia indescritíveis. Essa visão contribui infinitamente para que eu tenha, a cada dia, a consciência desperta para a importância da valorização e dos cuidados necessários com aquilo que sou e com aquilo que me cerca. 
"Onde meus talentos e paixões encontram as necessidades do mundo,

lá está meu caminho, meu lugar."

Aristóteles 


\section{RESUMO}

TURATI, A. O. Análise do perfil diário e dos mecanismos de síntese da melatonina pineal em ratos diabéticos por estreptozotocina tratados com insulina. 2013. 84 f. Dissertação (Mestrado em Fisiologia Humana) - Instituto de Ciências Biomédicas, Universidade de São Paulo, São Paulo, 2013.

Existem evidências sobre a queda na síntese de melatonina associada ao diabetes tipo I. A melatonina é o principal hormônio produzido pela glândula pineal durante o escotoperíodo e atua na regulação de diversos processos fisiológicos, dentre eles o metabolismo energético. A associação entre a redução de tal hormônio e o diabetes tipo I pode explicar diversas complicações relacionadas a esta patologia, como a menor capacidade antioxidativa que organismos com essa condição apresentam. $O$ presente estudo teve como objetivo verificar se a administração de insulina em animais diabéticos tipo I levaria a reversão na síntese de melatonina. Para tanto, animais de grupos independentes ou submetidos à microdiálise foram induzidos ao diabetes por estreptozotocina $(60 \mathrm{mg} / \mathrm{Kg})$, permanecendo nessa condição por 15 dias. Do terceiro dia da indução até o término do período os animais receberam a reposição de insulina duas vezes ao dia, antes do início da noite e após o começo da fase clara. A glicemia e o peso foram aferidos ao logo do bloco experimental. Os animais receberam água e alimento à vontade. No dia 15 , os animais foram pesados e foi realizada a eutanásia de forma circadiana destes. A melatonina foi dosada a partir da glândula pineal, por cromatografia líquida de alta eficiência com detecção eletroquímica (HPLC) e foram procedidos os testes para o conteúdo proteico (Western blot) e atividade enzimática da arilalquilamina-N-acetiltransferase (AANAT), assim como para o conteúdo de AMPc (ELISA) e para a atividade da $\mathrm{Na}^{+} / \mathrm{K}^{+}$ATPase (ensaio colorimétrico). A glicemia foi aferida no momento da eutanásia. Não foram constatadas alterações transcricionais envolvendo os receptores adrenérgicos presentes na glândula e as principais enzimas da via de síntese da indolamina em questão, conforme avaliado por RT-PCR. Foi possível verificar que houve reversão na queda da síntese de melatonina nos animais diabéticos tratados com insulina, de forma que esses apresentaram concentração hormonal semelhante àquela verificada para animais controles. Já os animais diabéticos revelaram queda na síntese hormonal, ganho de peso reduzido e altos índices glicêmicos. De tal maneira, a reversão na síntese de melatonina revela uma forte relação entre a melatonina e a insulina. $O$ hormônio pancreático parece modular a produção de melatonina. A normalização glicêmica em função do tratamento com insulina parece ser o fator preponderante para o reestabelecimento do nível de AMPc pineal, assim como do conteúdo proteico e da atividade da AANAT e, por conseqüência, para a reversão na produção de melatonina na glândula pineal já constatada após 2 dias do início do tratamento com insulina, conforme evidenciado por microdiálise. De tal maneira, a hiperglicemia aparece como o fator responsável pela desregulação da síntese da indolamina pineal, conforme constata-se pela cultura de células isoladas de pineais de animais controles em meio com elevada concentração de glicose. Ainda, essa desregulação pode estar atrelada ao funcionamento inadequado da $\mathrm{Na}^{+} / \mathrm{K}^{+} \mathrm{ATP}$ ase na glândula pineal.

Palavras-chave: Melatonina. Diabetes mellitus tipo I. Insulina. Hiperglicemia. 


\begin{abstract}
TURATI, A. O. Pineal melatonin synthesis daily profile and mechanisms in streptozotocin diabetic rats treated with insulin. 2013. 84 p. Masters thesis (Human Physiology) - Instituto de Ciências Biomédicas, Universidade de São Paulo, São Paulo, 2013.

There is evidence about the decrease in melatonin synthesis associated with type I diabetes. Melatonin is the principal hormone produced by the pineal gland during the dark period and acts on the regulation of various physiological processes, including the energy metabolism. The association between the reduction of this hormone and type I diabetes can explain various complications related to this pathology, as the reduced antioxidant capacity. The aim of the present study was to verify whether the administration of insulin to type I diabetic animals would lead to reversal in the bvvvvcaasynthesis of melatonin. Therefore, Wistar rats were rendered diabetic by streptozotocin $(60 \mathrm{mg} / \mathrm{Kg})$ and kept like that for a period of 15 days. From the third day of induction until the end of the period, the animals received the replacement of insulin, twice a day before the beginning and after the end of the dark period. Blood glucose and weight were measured during the experiment period. Animals received water and food ad libitum. On the 15th day, the animals were weighed and euthanized every 3 hours around the clock. Pineal melatonin was measured by high efficiency liquid chromatography with electrochemical detection (HPLC), arylalquilamine- $\mathrm{N}$-acetyltransferase (AANAT) protein (Western blot) and activity (radiometric assay) were also evaluated, as well as pineal AMPc content (ELISA) and $\mathrm{Na}^{+} / \mathrm{K}^{+}$pump activity (colorimetric assay). Blood glucose was measured the time of euthanasia. No difference in gene expression of the adrenergic receptors and main enzymes involved in melatonin synthesis was found by qPCR in pineal gland. It was possible to verify the restoration in melatonin synthesis in insulin-treated diabetic animals, as they presented similar levels of the pineal hormone observed in control animals. On the other hand, diabetic animals without insulin replacement exhibited a severe reduction in melatonin synthesis, lower weight gain and high blood glucose mean. Altogether, the reversal in impaired melatonin production in insulin-treated animals reveals a strong relation between melatonin and insulin. The pancreatic hormone seems to modulate pineal hormone synthesis. The glycemic adjustment due to insulin replacement in diabetic models appears to be crucial for appropriated pineal gland's physiology, since insulin-treated animals showed normal AMPc content, AANAT protein levels and activity and, consequently, regular melatonin production, observed after 2 days from the beginning of insulin treatment as noticed by microdialysis technique. Pineal cell culture corroborates the prejudicial effect of high glucose concentration evaluated in vivo. Such effect might be associated with inappropriate function of $\mathrm{Na}^{+} / \mathrm{K}^{+}$pump.
\end{abstract}

Keywords: Melatonin. Type 1 diabetes mellitus. Insulin. Hyperglycemia. 


\section{LISTA DE FIGURAS}

Figura 1 - Vias metabólicas existentes na glândula pineal. ....................................... 3

Figura 2 - Vias neurais de controle diário de síntese de melatonina pineal. ............. 4

Figura 3 - Estrutura química da melatonina. ..................................................... 8

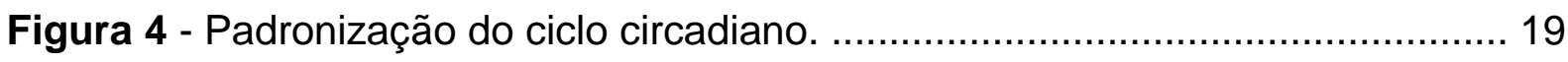

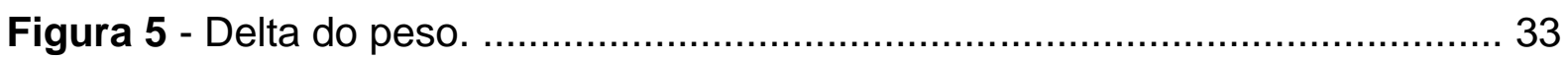

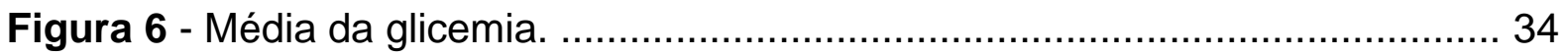

Figura 7 - Perfil da melatonina ao longo do escotoperíodo. ................................... 35

Figura 8 - Perfil da expressão gênica na glândula pineal. ...................................... 36

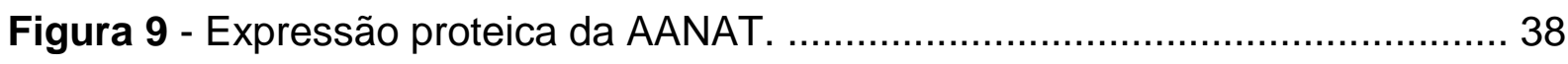

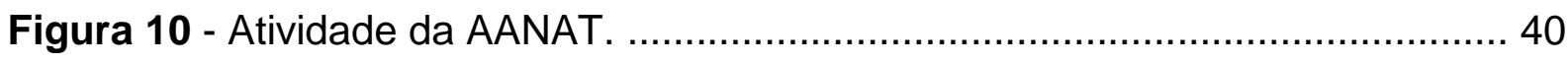

Figura 11 - Conteúdo de AMPc na glândula pineal durante o escotoperíodo. ........ 41

Figura 12 - Produção diária de melatonina avaliada por microdiálise. .................... 42

Figura 13 - Produção de melatonina em cultura de células isoladas de pineais mediante estímulo noradrenérgico.

Figura 14 - Produção de melatonina em cultura de células isoladas de pineais de ratos controles, diabéticos e diabéticos tratados com insulina.

Figura 15 - Atividade da $\mathrm{Na}^{+} / \mathrm{K}^{+}$pineal. 


\section{LISTA DE ABREVIATURAS}

AANAT - arilalquilamina $\mathrm{N}$-acetiltransferase

$A C$ - adenilil ciclase

Acetil CoA - acetil coenzima A

ADA - "American Diabetes Association"

AMPc - adenosina monofosfato cíclico

ANOVA - método de análise de variância

ATP - adenosina trifosfato

DNAc - DNA complementar

CEEA - Comissão de Ética em Experimentação Animal

COBEA - Colégio Brasileiro de Experimentação Animal

CRE - "CAMP response element"

CREB - "CAMP response element binding"

DAG - diacilglicerol

DB-AMPc - Dibutiril-AMPc

DM - diabetes mellitus

DMEM - "Dulbecco's Modified Eagle Médium"

DNA - ácido desoxirribonucléico

EDTA - ácido etilenodiamino tetra-acético

GABA - ácido gama-aminobutírico

GLUT2 - transportador de glicose 2

GLUT4 - transportador de glicose 4

GMPc - guanosina monofosfato cíclico

HEPES - ácido N-2-Hidroxietilpiperazina-N'-2'-Etanossulfônico

HIOMT - hidroxindol-oxi-metiltransferase

HPLC - cromatografia líquida de alta eficiência

ICER - "inducible cAMP early repressor"

IDF - "International Diabetes Federation"

IGF-1 - "insulin growth factor 1"

IP3 - trifosfato de inositol

IR - "insulin receptor"

IRS-1 - substrato 1 para o receptor de insulina

MAPK - proteína quinase ativada por mitógeno 
MT1 - receptor 1 de membrana para melatonina

MT2 - receptor 2 de membrana para melatonina

MT3 - receptor 3 de membrana para melatonina

NAS - N-acetilserotonina

NOD mouse - "non-obese diabetic mouse"

NOS - "nitric oxide synthase"

NPY - neuropeptídeo Y

OLEFT - "Otsuka Long-Evans Tokushima Fatty"

PCR - reação em cadeia da polimerase

PDE 4B2 - fosfodiesterase 4B2

$\mathrm{PI}$ - iodeto de propídeo

$\mathrm{PI3}$ - fosfatidilinositol 3-quinase

PKA - proteína quinase $A$

PKC - proteína quinase $C$

PSP 1 - "protein serine/threonine phosphatase 1"

RNA - ácido ribonucléico

RNAm - RNA mensageiro

RZR/ROR - receptors nucleares órfãos relacionados ao ácido retinóico

STZ - estreptozotocina

TPH - triptofano hidroxilase

ZDF - "Zucker Diabetic Fatty"

ZT - "Zeitgeber Time" 


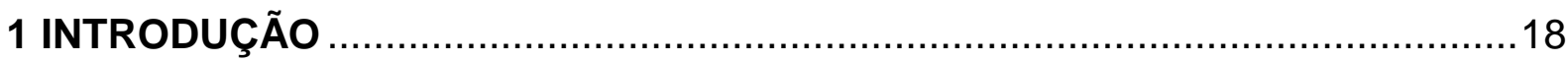

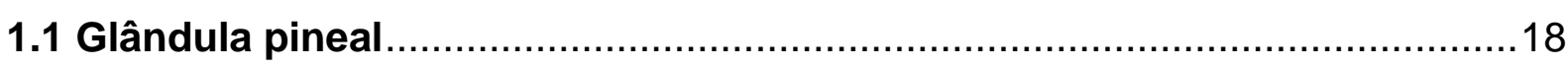

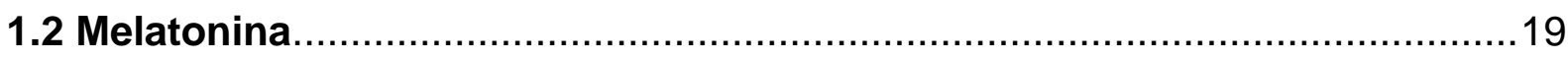

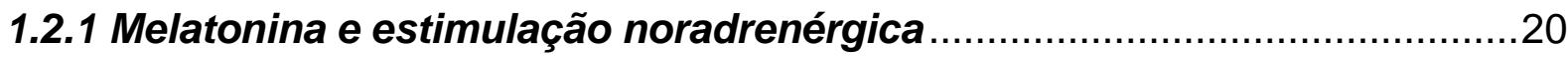

1.2.2 Enzimas da via de síntese da melatonina ............................................22

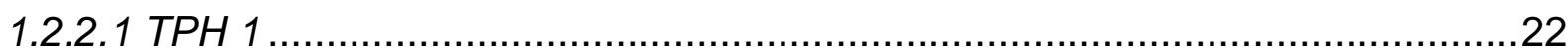

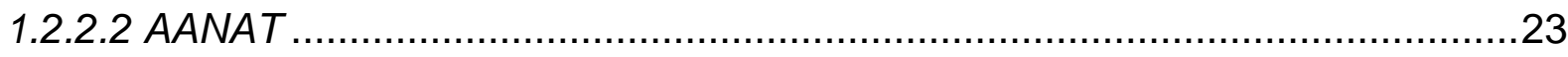

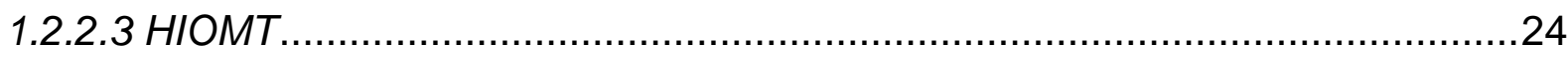

1.2.3 Secreção da melatonina e suas propriedades........................................25

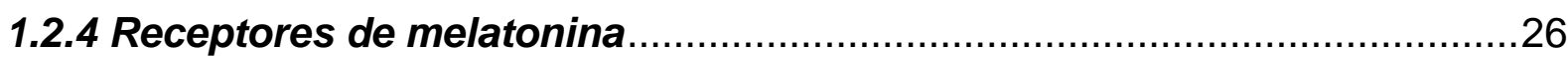

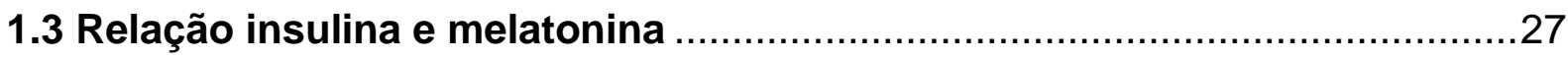

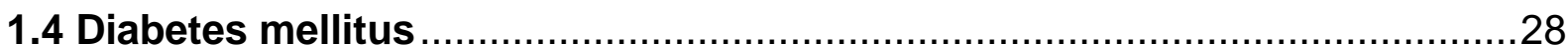

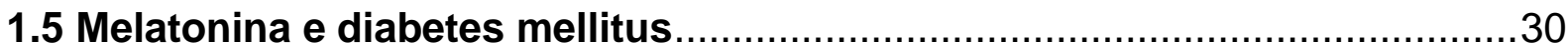

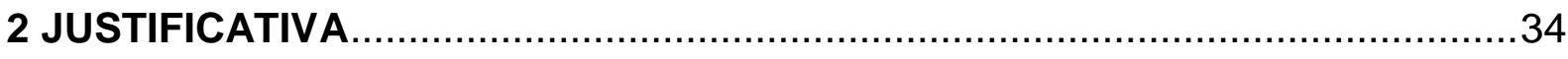

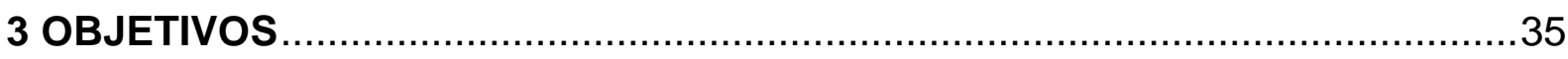

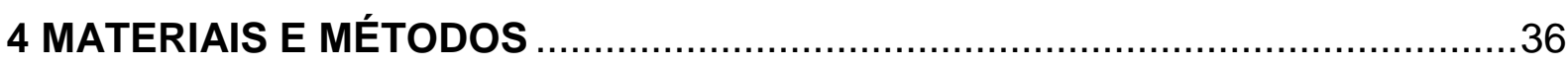

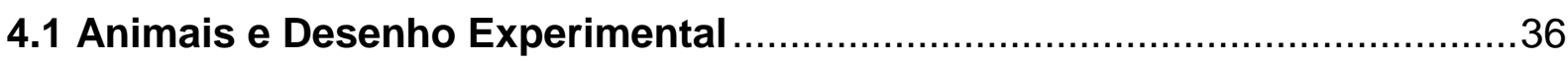

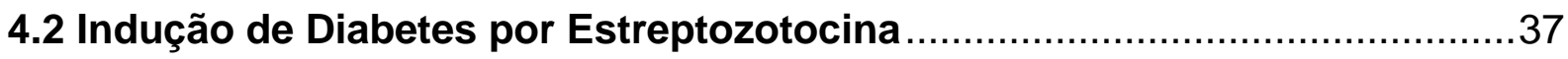

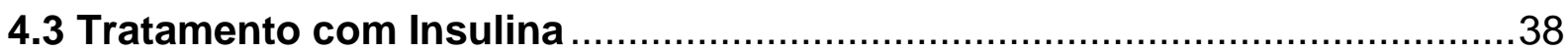

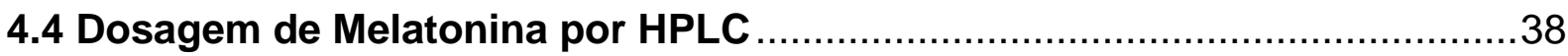

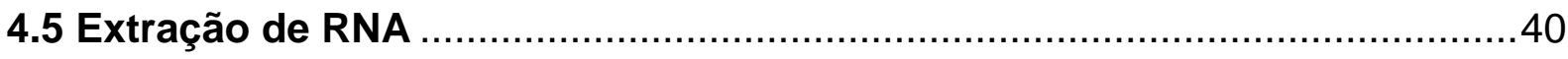

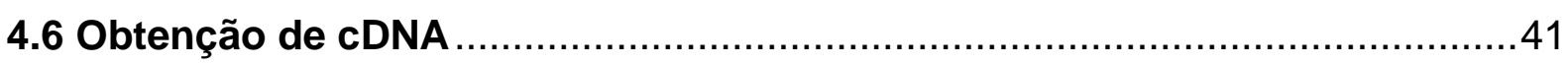

4.7 Análise quantitativa da expressão gênica por reação de PCR em tempo real

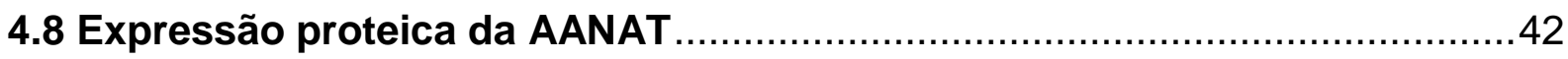

4.9 Análise Radiométrica da Atividade Enzimática da AANAT ..........................43

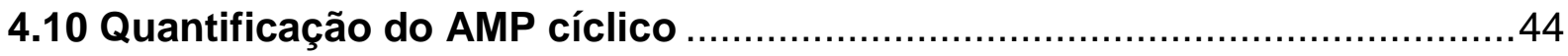

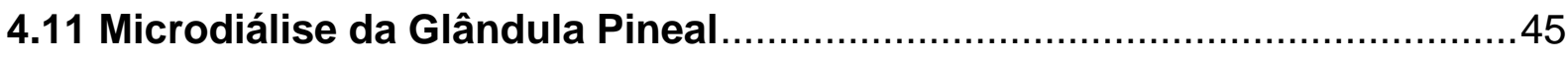

4.12 Dissociação celular da glândula pineal e cultura de suas células isoladas

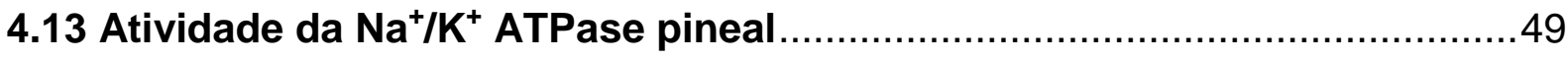

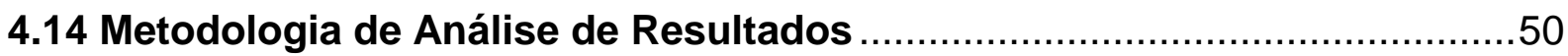


5 RESULTADOS

5.1 Peso

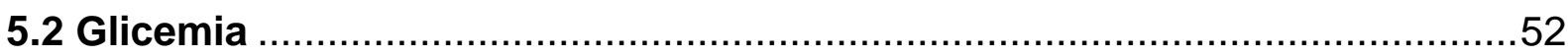

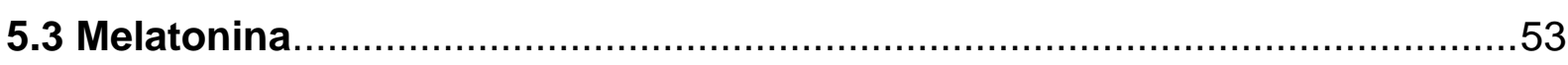

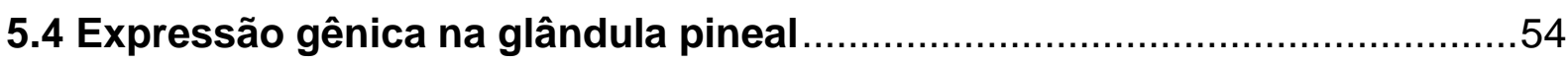

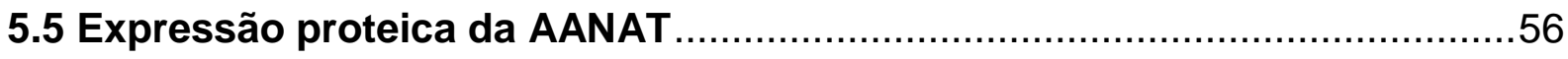

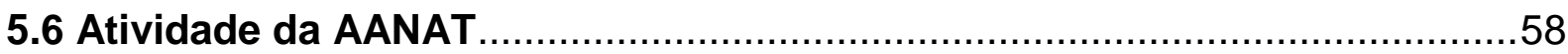

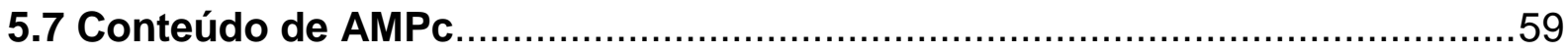

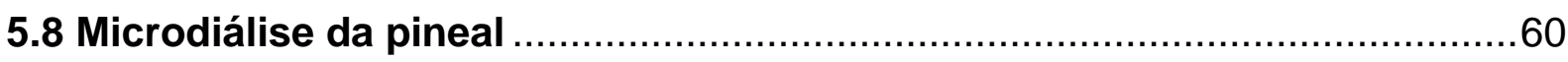

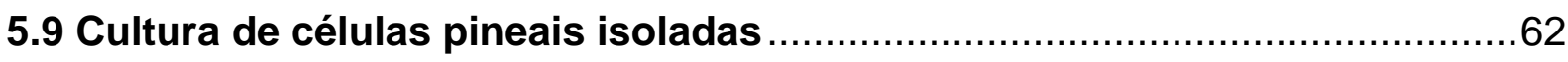

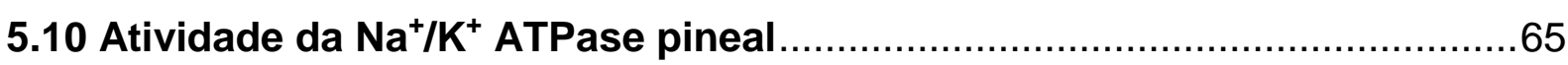

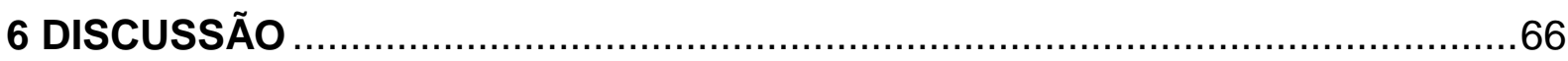

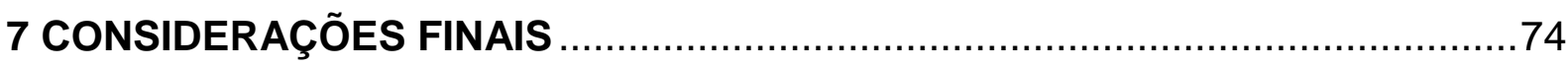

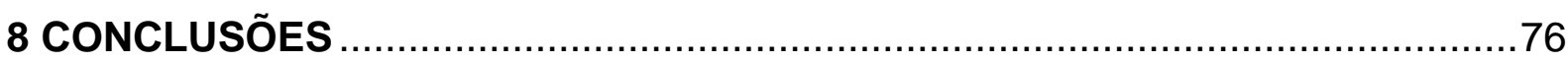

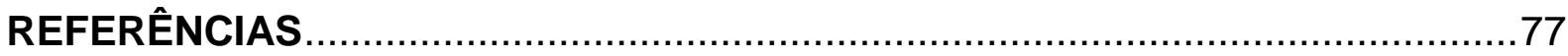




\section{INTRODUÇÃO}

\subsection{Glândula pineal}

Primeiramente descrita por Galeano de Pérgamo entre os séculos III e IV a.C, a glândula pineal recebeu diversas atribuições desde então, sendo até mesmo considerada a "sede da alma" por René Descartes (ARENDT, 1995).

A denominação da glândula pineal deriva de seu formato verificado em seres humanos, semelhante a uma pinha, com dimensão aproximada de $6 \mathrm{~mm}$ em seu maior eixo. Sua origem embrionária está associada a uma evaginação do III ventrículo, constituindo uma parte do epitálamo. Em seres humanos está localizada acima dos colículos superiores, na região posterior do teto diencefálico (CALDAS et al., 1998).

A glândula pineal passa de um órgão predominantemente fotossensível em algumas classes de vertebrados, como peixes, anfíbios, répteis e aves (COLLIN, 1971) para uma estrutura de caráter neuroendócrino em mamíferos, recebendo informações indiretas a respeito da iluminação ambiental por meio da via retinohipotalâmica e do sistema nervoso simpático (VOLLRATH, 1981). Tal alteração da condição fotossensível para a neuroendócrina é reforçada por mudanças morfológicas e funcionais sofridas pelo principal constituinte celular da glândula pineal, o pinealócito. Observações filogenéticas a respeito desse tipo celular indicam queda na quantidade das variedades fotoreceptoras e crescente predomínio de pinealócitos neurossecretores conforme nos aproximamos dos mamíferos na escala evolutiva (EKSTRÖM; MEISSL, 2003).

Sua função está associada à sincronização entre os ritmos endógenos e o ritmo de claro-escuro ambiental de aproximadamente 24 horas, ou seja, o ritmo circadiano, de forma que a produção de melatonina ocorre exclusivamente no período do escuro, também chamado de escotoperíodo, independente do momento de maior atividade da espécie considerada. Assim, por sua presença plasmática a melatonina indica ao organismo o período noturno, enquanto a duração do episódio secretório noturno representa a sazonalidade (REITER, 1993).

A glândula pineal atua como um temporizador interno, tendo como mediadora a melatonina e estando associada a diversos processos que vão desde a coordenação dos ritmos circadianos e sazonais até a regulação de processos endócrinos, metabólicos, reprodutivos, imunes e de função cardiovascular. A 
melatonina pode ainda ser considerada um marcador ontogenético, considerando a variação de sua produção em cada fase da vida, sendo maior na infância e reduzida na velhice (CIPOLLA-NETO; AFECHE, 2008).

Existem outros locais de síntese da melatonina, tais como a retina e o sistema gastrintestinal, entretanto acredita-se que a melatonina sintetizada nestas regiões tenha maior importância na modulação de fenômenos locais (ARENDT, 1995).

\subsection{Melatonina}

A melatonina ( $\mathrm{N}$-acetil-5-metoxitriptamina) é uma indolamina de peso molecular 232,3 que foi isolada em 1958 a partir de glândulas pineais bovinas (LERNER et al., 1958).

Sua denominação deveu-se a primeira propriedade identificada e que estava associada a coloração de pele de anfíbios e peixes (HARDELAND et al., 2011). No entanto, foi apenas na década de 80 que a melatonina tornou-se de alvo de interesse por seu papel regulatório dos ritmos circadianos em diversos organismos.

É válido ressaltar que tal papel foi considerado como função principal e quase exclusiva da indolamina em questão por muitos anos até o surgimento de novos estudos apontando para a diversidade de estruturas que a produzem, ampla distribuição de receptores, variedade quanto a sinalização e função intracelular, assim como multiplicidade de órgãos-alvo, conforme indicam Hardeland et al., 2011.

Sua síntese ocorre a partir do aminoácido essencial triptofano que é transformado em 5-hidroxitriptofano (5-HTP) pela triptofano hidroxilase 1 (TPH1, EC 1.14.16.4). O 5-HTP passa por uma descarboxilação catalisada pela descarboxilase de I-aminoácidos aromáticos (EC 4.1.1.28) que resulta na formação de serotonina (5-HT). A serotonina é então acetilada pela arilalquilamina-N-acetiltransferase (AANAT, EC 2.3.1.87) e transformada em $\mathrm{N}$-acetilserotonina (NAS), que tem o grupamento hidroxila trocado por um metil pela ação da hidroxindol-oximetiltransferase (HIOMT, EC 2.1.1.4), culminando na formação da melatonina (CIPOLLA-NETO et al., 1999). O processo descrito acima está representado na Figura 1 localizada a seguir. 
Figura 1 - Vias metabólicas existentes na glândula pineal.

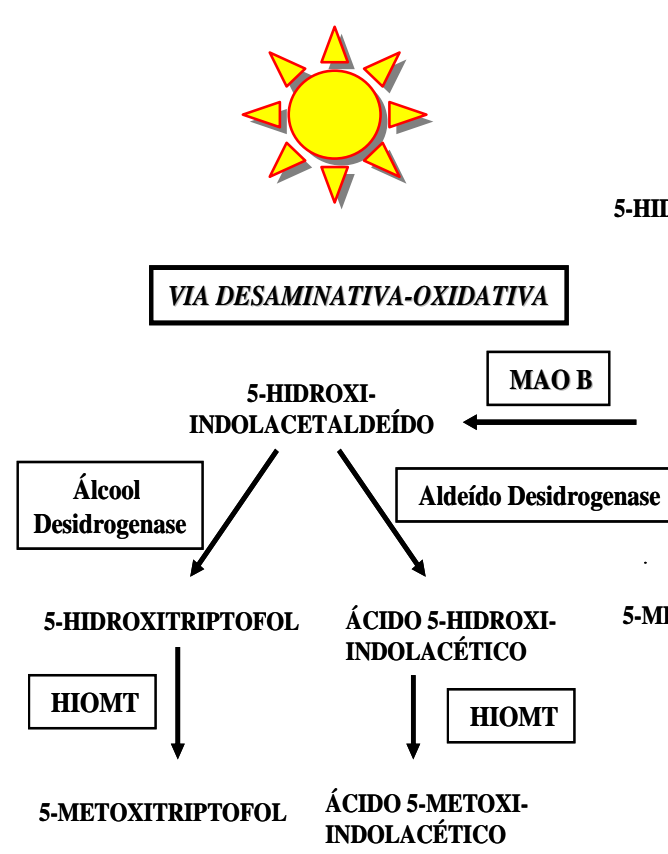

TRIPTOFANO
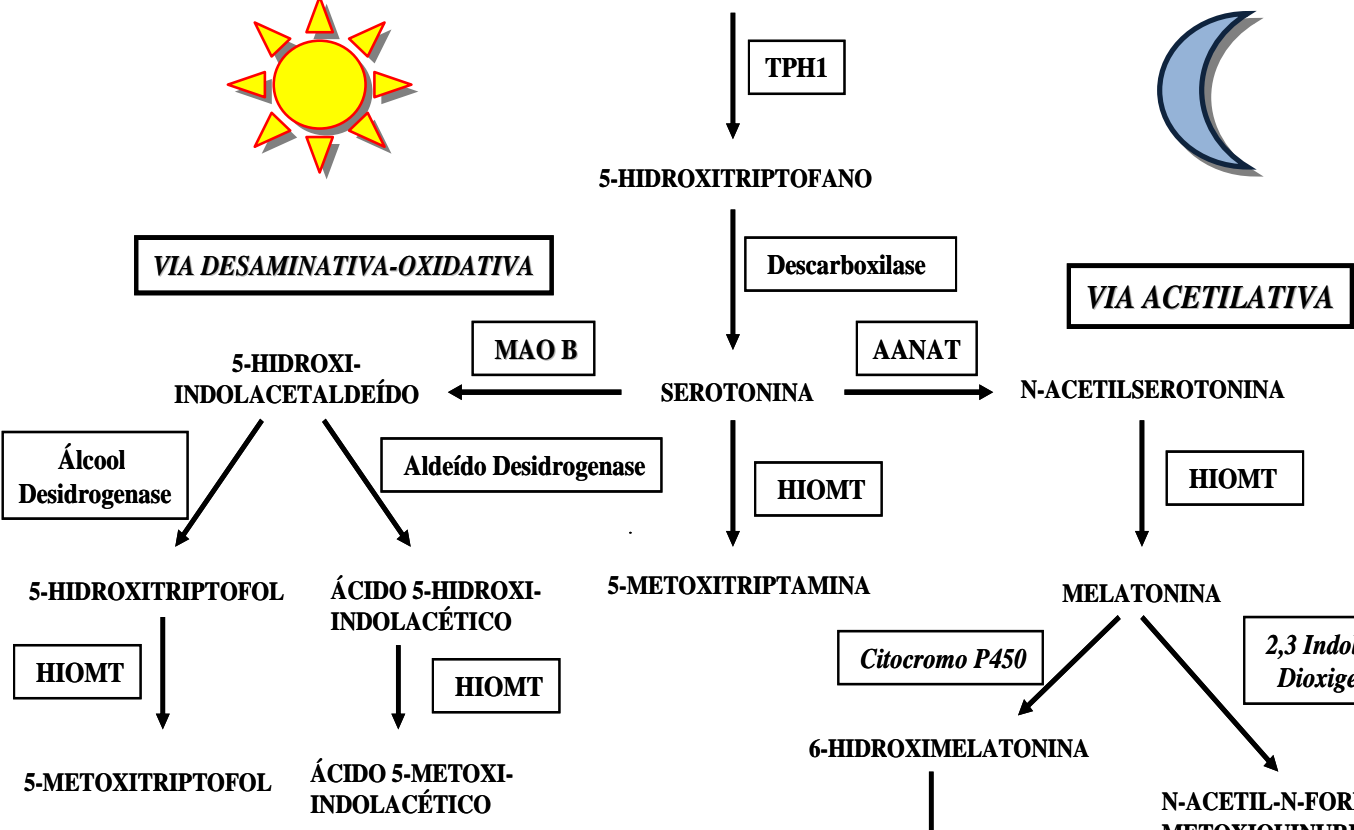

5-METOXITRIPTAMINA

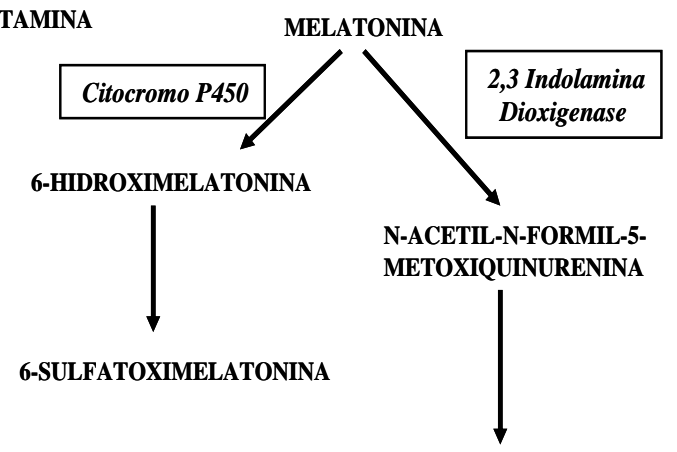

N-ACETIL-5-METOXIQUINURENINA

A figura representa as vias metabólicas de síntese e degradação da melatonina e de outros indóis na glândula pineal

Fonte: Adaptado de Cipolla-Neto e Afeche, 2008.

\subsubsection{Melatonina e estimulação noradrenérgica}

O controle neural do metabolismo da glândula pineal origina-se no núcleo paraventricular do hipotálamo que se projeta para coluna intermédio-lateral da medula torácica alta, nos neurônios pré-ganglionares do sistema nervoso autônomo simpático. Estes neurônios projetam-se então para os gânglios cervicais superiores, cujos neurônios pós-ganglionares chegam a glândula pineal através dos ramos carotídeos internos e nervos conários (CIPOLLA-NETO; AFECHE, 2008).

O ritmo da síntese diária de melatonina é sincronizado ao ciclo claro-escuro ambiental a partir da informação que segue pela via retino-hipotalâmica, resultando em queda na inibição do núcleo paraventricular, a qual era resultante da liberação 
do ácido gama-aminobutírico (GABA) pelo núcleo supraquiasmático quando em presença do estímulo luminoso (CIPOLLA-NETO; AFECHE, 2008).

A Figura 2 representa as estruturas neurais envolvidas no controle da síntese de melatonina, assim como no estabelecimento de sua sincronia com a iluminação ambiental.

Figura 2 - Vias neurais do controle diário da síntese de melatonina pineal

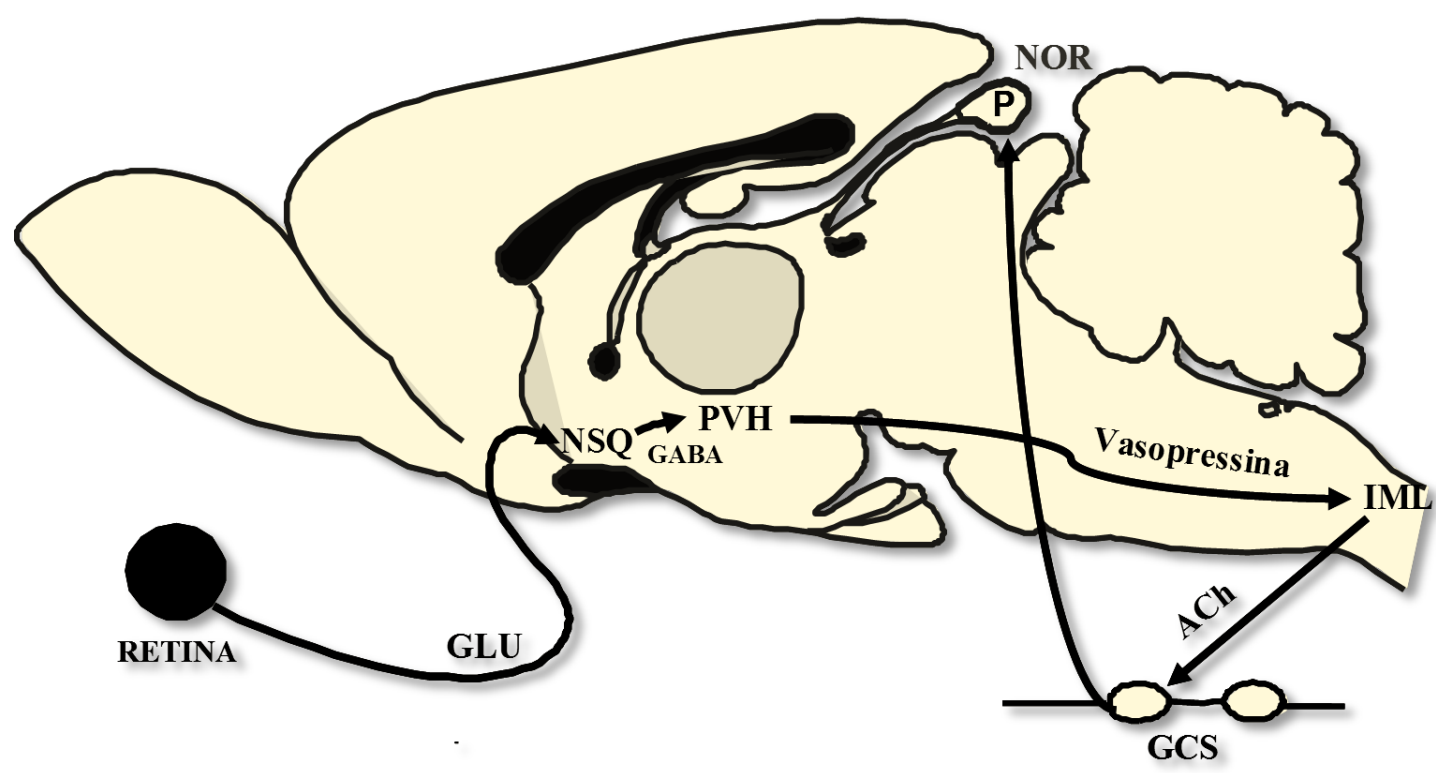

Vias neurais do controle diário da síntese de melatonina pineal e os principais neurotransmissores envolvidos. GLU: glutamato; NSQ: núcleo supraquiasmático; GABA: ácido gama-aminobutírico; PVH: núcleo paraventricular hipotalâmico; IML: coluna intermédio-lateral da medula espinhal; Ach: acetilcolina; GCS: gânglio simpático cervical superior; P: pineal; NOR: noradrenalina.

Fonte: Adaptado de Cipolla-Neto e Afeche, 2008.

Assim, a ativação noturna da via neural de projeção periférica para a glândula pineal induz a liberação de noradrenalina nas proximidades dos pinealócitos, os quais apresentam receptores a e $\beta$-adrenérgicos (VANECK et al., 1985). Da interação com os receptores $\beta$ (subtipo $\beta_{1}$ ) há indução do aumento do monofosfato de adenosina cíclico (AMPc) intracelular através da ativação de proteína $G$ estimulatória (Gs) e da enzima adenilil ciclase ( $A C$ ). Além da via desencadeada pela atuação da noradrenalina em receptores $\beta$ na pineal, principal responsável pela elevação noturna do conteúdo da indolamina, a estimulação de receptores adrenérgicos a1 também contribui de forma sinérgica para o aumento gerado nos níveis de $A M P c$, tanto in vitro quanto in vivo, como reflexo da potenciação da 
ativação da enzima adenilil ciclase (AC) (KLEIN et al., 1983), em processos envolvendo o aumento no influxo de cálcio com consequente ativação da proteína quinase depende desse íon (PKC) (SUGDEN et al., 1985, 1986, 1987).

Ainda, o cálcio tem um papel potenciador da síntese do AMPc intracelular também por atuar através do complexo cálcio/calmodulina na ativação da adenilil ciclase, que na glândula pineal foi caracterizada como sendo do tipo 1 (TZAVARA et al., 1996).

Um regulador negativo do AMPc na glândula pineal é a variante PDE4B2, uma fosfodiesterase identificada na pineal de ratos e que exibe flutuação diária com aumento na segunda metade da noite de seis vezes em sua expressão gênica em função do estímulo adrenérgico da via do próprio AMPc e da proteína quinase dependente do AMPc (PKA). O aumento no RNA mensageiro (mRNA) de PDE4B2 se reflete diretamente no conteúdo proteico e na atividade enzimática, contribuindo para a redução de melatonina nos momentos finais da noite (KIM et al., 2007).

\subsubsection{Enzimas da via de síntese da melatonina}

\subsubsection{TPH 1}

A triptofano hidroxilase 1 (TPH1) caracteriza a enzima mais importante da via de síntese da serotonina na glândula pineal, dada a variação de sua atividade ao longo do dia, enquanto a descarboxilase tem sua expressão constitutiva durante as $24 \mathrm{~h}$.

É importante destacar que o conteúdo de serotonina apresenta variações circadianas na pineal (KLEIN; WELLER, 1970), com valores altos durante a fase clara e elevação logo no começo da noite, seguido de queda abrupta associada a geração de $\mathrm{N}$-acetilserotonina e melatonina. Esse aumento noturno está associado a fosforilação de TPH1 em serina 58 pela PKA, fato desencadeado pelo aumento de AMPc resultante do estímulo noradrenérgico nos adrenoceptores presentes na glândula pineal. Assim, há uma regulação pós-traducional modulando a sua atividade durante a noite. O ritmo de serotonina se mantém mesmo na condição de escuro constante, revelando o caráter endógeno dessa oscilação (HUANG et al., 2008). 


\subsubsection{AANAT}

Os primeiros estudos destacando a relevância da AANAT para a síntese de melatonina pineal avaliaram os resultados da estimulação noradrenérgica na elevação do conteúdo dos segundos mensageiros celulares, o que estava associado a modulação da atividade dessa enzima, que exibe clara ritmicidade ao longo das 24 horas com elevação noturna correspondendo ao período de síntese da melatonina (KLEIN et al., 1970; KLEIN; WELLER, 1970, 1972; PARFITT et al., 1976; YU et al., 1993).

Grande parte das investigações a respeito da transcrição rítmica da AANAT envolveram modelos murinos, assim como cultura de pinealócitos ou do órgão pineal em si. Roseboom et al., 1996 evidenciaram um aumento dependente da atuação da noradrenalina em receptores $\beta$ e da sinalização por AMPc de cento e cinquenta vezes na expressão da AANAT em pineais de ratos, processo de ocorrência predominantemente noturna.

Estudos in vivo investigando a dinâmica entre os eventos de estimulação noradrenérgica, aumento de AMPc, ativação de PKA e maior transcrição da AANAT com consequência direta na síntese noturna de melatonina evidenciaram a atuação dos fatores de transcrição do elemento de ligação responsivo ao AMPc (CREB) e do elemento inibidor responsivo ao AMPc (ICER) para ratos. O fator CREB torna-se ativo mediante sua fosforilação ( $\mathrm{pCREB}$ ) em serina 133 via PKA que tem lugar na primeira parte da noite, o que está relacionado a manutenção de elevadas taxas de transcrição, como é observado para o gene da AANAT. Esse fenômeno se sobrepõe à ação inibitória de ICER até o ponto em que tem início a desfosforilação de CREB, independente da continuidade do estímulo por noradrenalina. Em paralelo a queda no conteúdo de pCREB, eleva-se a proteína de ICER, que compete pela ligação em CRE regulando negativamente a transcrição gênica da AANAT e de outros genes e corroborando para a queda de melatonina durante a noite (MARONDE et al., 1999). Em tal processo, a atuação de fosfatases de serina/treonina, mais especificamente da variante 1 de ação nuclear, a PSP 1 , contribui para a queda no conteúdo de pCREB em pinealócitos de ratos (KOCH et al., 2003).

Antes da elucidação de processos moleculares da transcrição da AANAT, alguns estudos já apontavam para uma associação entre a atividade dessa enzima e as variações no conteúdo de AMPc. Assim, era observado que análogos de AMPc 
atuavam como favorecedores do processo de acetilação da serotonina em pineal de ratos (KLEIN et al., 1970), enquanto a queda no conteúdo de AMPc por redução em sua síntese ou crescente metabolização eram associados a interrupção na atividade da AANAT em cultura de pinealócitos (KLEIN et al., 1978).

O aumento da transcrição da enzima, em torno de cento e cinquenta vezes (ROSEBOOM et al., 1996), repercute em maior quantidade da proteína e ainda em sua atividade, que pode atingir valores de dez a cem vezes superior àqueles registrados para a fase clara do dia. A elevação do mRNA da AANAT está condicionada ao início da fase escura e, portanto, ao início da liberação de noradrenalina nos adrenoceptores $\alpha_{1}$ e $\beta_{1}$ dos pinealócitos, reforçando a natureza endógena dessa oscilação (RIBELAYGA et al., 1999a).

\subsubsection{HIOMT}

A transcrição do mRNA da AANAT parece ser regulada exclusivamente pela estimulação noradrenérgica em receptores do tipo $\beta 1$, o que gera um acúmulo noturno de mRNA da enzima na glândula pineal de ratos, passível de redução pela exposição à luz durante esse período (RIBELAYGA et al., 1999a). Da mesma forma que ocorre com a expressão do gene da AANAT, o mRNA da HIOMT tem seu aumento vinculado ao início da fase escura, o que indica a dependência dessas variações em relação ao fotoperíodo (RIBELAYGA et al., 1999b).

De acordo com Ribelayga et al., 1997, 1999a e 1999b, a atividade da HIOMT exibe uma regulação complexa, sem relação direta entre expressão e atividade e com interferência de outros fatores em seu controle diário, além da estimulação adrenérgica.

Assim, a noradrenalina atuando nos receptores $\alpha$ e $\beta$ parece desempenhar influência apenas na manutenção a longo prazo da atividade da HIOMT em virtude de um controle que leva ao acúmulo diário de seu transcrito e de sua proteína, contribuindo para a manutenção de sua atividade basal, de forma que o aumento na transcrição durante a noite não tem reflexo imediato na atividade da enzima (RIBELAYGA et al., 1999b). Esses achados corroboram estudos mais antigos em que a atividade da HIOMT não apresentou alteração em cultura de glândulas pineais estimuladas agudamente com dibutiril AMPc (DB-AMPc), evidenciando a nãointerferência imediata da via de estimulação noradrenérgica (KLEIN et al., 1970). 
O controle agudo de sua atividade está associado a atuação de peptídeos como o neuropeptídeo Y (NPY), que eleva a atividade da HIOMT em $40 \%$ (RIBELAYGA et al., 1997). É importante destacar que estudos do mesmo grupo revelaram um discreto aumento de $30 \%$ na atividade da HIOMT in vivo durante a noite quando comparado aos valores encontrados para a fase clara do dia (RIBELAYGA et al., 1999b).

\subsubsection{Secreção da melatonina e suas propriedades}

O total de melatonina produzida durante a noite é prontamente secretado (CIPOLLA-NETO; AFECHE, 2008), sendo liberado para a região perivascular glandular quando ocorre sua difusão para o sangue, onde 0 transporte se dá em combinação com a albumina (CARDINALI; VACAS, 1987). A concentração plasmática de pico da indolamina durante o escotoperíodo é, no rato, de aproximadamente $100 \mathrm{pg} / \mathrm{mL}$ (VOLLRATH, 1981).

Suas propriedades químicas, dadas pela presença dos grupamentos metoxi no carbono 5 e acetil ligado ao nitrogênio do grupo amina, conferem anfifilicidade a molécula, conforme evidenciado na Figura 3. Ainda, os carbonos 2 e 3 do anel pirrólico apresentam capacidade redutora, fazendo da melatonina um potente antioxidante (CIPOLLA-NETO; AFECHE, 2008).

Figura 3 - Estrutura química da melatonina.

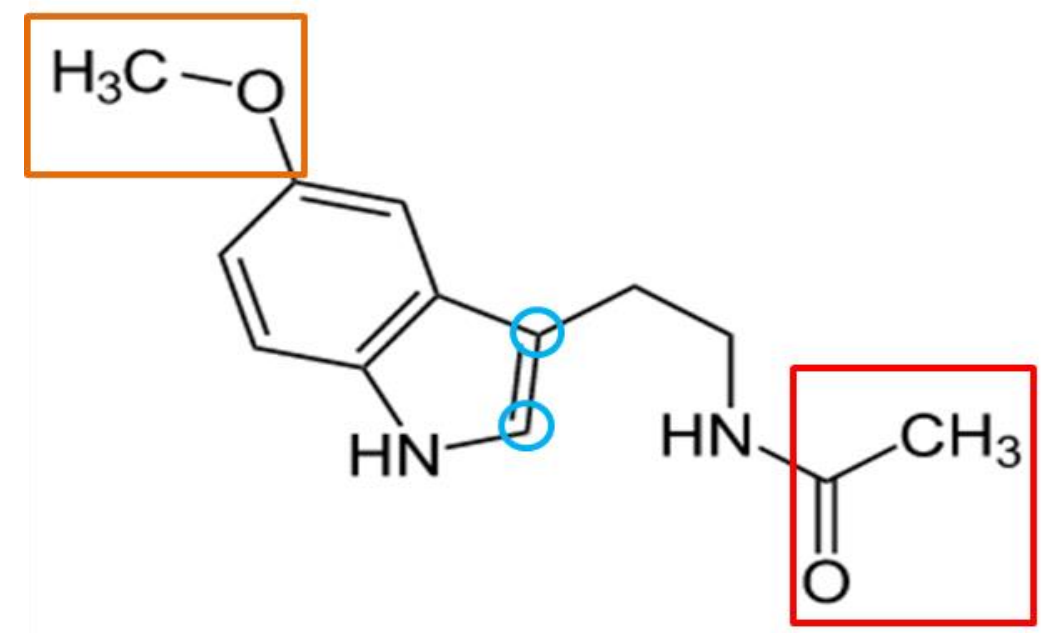

No quadrado laranja à esquerda está destacado o grupamento metoxi e em vermelho, à direita, o grupamento acetil. Os círculos azuis indicam os carbonos 2 e 3, constituintes do anel pirrólico da melatonina e que apresentam alto poder redutor. 
A melatonina desempenha diversas funções nos seres vivos, além da sinalização circadiana e do papel de antioxidante, que podem ou não serem mediadas por receptores. A interação direta da melatonina com outras moléculas dá a ela a capacidade de agir mobilizando mecanismos reparadores do DNA e regulando o processo de apoptose celular (LUCHETTI et al., 2010), além de modular diretamente a ação de diversas enzimas, regulando também o metabolismo oxidativo e o transporte de elétrons pela sua ação intra-mitocondrial (REITER et al., 2004).

\subsubsection{Receptores de melatonina}

Nos mamíferos estão bem caracterizados dois tipos de receptores de membrana para melatonina (DUBOCOVICH, 1995). São esses os receptores de alta afinidade $\mathrm{MT}_{1}$ e $\mathrm{MT}_{2}$ pertencentes à superfamília dos receptores ligados à proteína G. Mediante ligação do MT1 com uma proteína $G_{i}$ pode ocorrer uma redução na produção do AMPc (MORGAN et al., 1994) ou ainda aumento dos mensageiros resultantes da ativação da via da fosfolipase $C$ (PLC), o diacilglicerol (DAG) e o trifosfato de inositol (IP3) quando a ligação se dá com um proteína $G_{q}$ (BARRET et al., 1996). O receptor MT2 pode estar associado a queda no conteúdo de GMPc intracelular (REPPERT et al., 1995). Os receptores de alta afinidade estão distribuídos por todo o organismo desde o sistema nervoso central, onde está presente em várias estruturas, até órgãos e tecidos da periferia (Dubocovich; Markowska, 2005).

Reppert et al., 1996 descreveram um terceiro tipo de receptor de membrana para melatonina existente em mamíferos, o $\mathrm{MT}_{3}$. No entanto, tal sítio de ligação é hoje considerado uma quinona redutase do tipo 2 , de cuja ativação resultam efeitos antioxidantes e ainda ações no metabolismo energético (Mailliet et al., 2005; Slominski et al., 2012). É importante destacar que existem ainda outras proteínas descritas que podem se ligar a melatonina, como é o caso da calmodulina (Turjanski et al., 2004).

O receptor nuclear conhecido para a melatonina é um dos receptores órfãos da família dos receptores de ácido retinóico do tipo RZR/ROR (PARK et al., 1997). 


\subsection{Relação insulina e melatonina}

A glândula pineal apresenta receptores para diferentes hormônios (CIPOLLANETO; AFECHE, 2008). Como conseqüência desse fato a produção de melatonina está sujeita não apenas ao controle neural, que envolve as descargas enviadas pelo gânglio cervical superior, mas também a modulação por hormônios, como é o caso da insulina. Alguns trabalhos tem demonstrado a influência do hormônio pancreático em etapas da via de síntese da indolamina em questão, enquanto outros demonstram a interferência da melatonina em eventos desencadeados pela insulina.

Lima et al. (1994) evidenciaram que a melatonina eleva a sensibilidade de adipócitos isolados à atuação da insulina, elevando a captação de glicose. Em 1998, outro trabalho do mesmo grupo revelou que a pinealectomia em ratos gera uma condição de resistência insulínica, evidenciada pelo teste de tolerância à glicose intravenosa (IVGTT), associada a uma redução de $40 \%$ dos transportares GLUT 4 tanto em adipócitos quanto em células musculares. Corroborando esses dados, Zanqueta et al. (2003) constataram uma queda de aproximadamente $70 \%$ nas expressões gênica e proteica de GLUT 4 no tecido adiposo branco, contribuindo para a resistência insulínica verificada para esses animais, enquanto que a reposição com melatonina se mostrou eficaz em normalizar esses parâmetros. Tais estudos reforçam a relação existente entre os hormônios pancreático e pineal.

Garcia et al. (2008) demonstraram que culturas de glândula pineal que recebiam insulina, em concentração fisiológica de $10^{-8} \mathrm{M}$, juntamente com noradrenalina a uma concentração de $10^{-6} \mathrm{M}$ apresentaram a produção de melatonina potencializada. A respeito desse estudo é válido destacar que a potenciação na síntese de melatonina foi verificada em cultura padrão e de forma ainda mais expressiva em cultura sincronizada, na qual as glândulas recebiam 12 horas de estimulação com noradrenalina, seguidas de 12 horas na ausência de noradrenalina, objetivando-se mimetizar a estimulação que tal estrutura recebe invivo.

É importante ressaltar que tal aumento foi mais significativo ao mimetizar os períodos de estímulo da cultura, com o hormônio e neurotransmissor, ao ciclo circadiano, ou seja, $12 \mathrm{~h}$ de ativação da glândula pineal, seguidas por $12 \mathrm{~h}$ na ausência do estímulo na cultura sincronizada. 
A potenciação da insulina na síntese de melatonina mediada por noradrenalina foi atribuída à elevação na atividade da triptofano-hidroxilase (TPH 1) assim como da arilalquilamina- $\mathrm{N}$-acetiltransferase (AANAT), principalmente na cultura sincronizada em prováveis eventos posteriores à transcrição. Isso é corroborado pela não alteração da expressão gênica das enzimas em questão, de acordo com Garcia et al. (2008). O estímulo à atividade da AANAT parece ser ocasionado por ação direta ou indireta da fosfatidilinositol-3-quinase (PI3K). De tal maneira, a insulina parece atuar como potenciadora da síntese de melatonina (Garcia et al., 2010).

Por outro lado, a influência da melatonina na insulina é verificada na sincronização da secreção das ilhotas pancreáticas em relação a fase do ciclo claroescuro ambiental frente a um estímulo com glicose (PICINATO et al., 2002a e 2002b), sendo esta fase associada ao momento de maior atividade de um organismo, que coincide com o início do escotoperíodo em roedores. Esses autores verificaram a perda no ritmo e na capacidade secretora de insulina pelo menor conteúdo de PKA pancreática, assim como alteração da oxidação de glicose pelas células $\beta$-pancreáticas em animais com ausência crônica da pineal.

Além da influência na secreção insulínica, a melatonina ainda aumenta a sensibilidade dos tecidos periféricos e no sistema nervoso central à insulina ao promover a ativação dos seus receptores (ANHÊ et al., 2004; PICINATO et al., 2008) e aumentar a síntese de GLUT4 em alguns tecidos (Seraphim et al, 1997).

\subsection{Diabetes mellitus}

De acordo com a International Diabetes Federation (IDF), em 2012, aproximadamente 366 milhões de pessoas na idade adulta eram consideradas diabéticas, em uma estimativa obtida a partir das sete regiões mundiais que são monitoradas pela organização. As previsões apontam para valores próximos de 552 milhões de diabéticos no mundo em 2030, o que equivale dizer que uma em cada dez pessoas terá diabetes mellitus na data em questão. Ainda nesse aspecto, é importante destacar algumas estimativas que indicam aproximadamente 183 milhões de indivíduos que apresentam a condição e não estão diagnosticados. No Brasil, em 2012, a IDF identificou aproximadamente 13.4 milhões de pessoas como 
portadores de diabetes, sendo o quarto país com maior número de indivíduos afetados, atrás somente da China, Índia e Estados Unidos da América.

Segunda a American Diabetes Association (ADA), o diabetes mellitus (DM) é um dos fatores componentes da síndrome metabólica, classificando-se em: DM do tipo I, também conhecida como insulino-dependente ou ainda juvenil, em virtude da faixa etária em que a condição costuma se manifestar e DM do tipo II, considerada tardia por incidir predominantemente na população adulta. Essa variedade está associada a baixa produção de insulina ou ação ineficaz desse hormônio. A hiperglicemia é um fator comum às duas manifestações da síndrome.

A causa primordial responsável pelo diabetes mellitus tipo I, conforme evidenciam a IDF e a ADA, é a não produção de insulina pelas células $\beta$ do pâncreas, resultante de uma ação auto-imune. Do total de pacientes diabéticos, apenas 5\% são acometidos pelo DM tipo I, sendo a maioria composta por crianças e adolescentes. O tratamento inadequado ou inexistente dessa condição pode conduzir a várias complicações, como cegueira, falência renal, doenças cardiovasculares, neuropatia e até mesmo amputação de membros.

A insulina humana recombinante, substituinte daquela de origem animal, viabilizou o ajuste das doses hormonais à concentração de glicose no sangue, variável ao longo do dia em função da ingestão alimentar (MARZZOCO; TORRES, 2007) e caracteriza a principal forma de tratamento de indivíduos acometidos pelo DM tipo I.

Atualmente, existem variadas abordagens como o uso de bombas de insulina e de medicamentos coadjuvantes, como a metformina, no tratamento de pacientes dependentes de insulina (DANEMAN, 2006) além da já citada reposição hormonal que se realiza tradicionalmente por meio de injeções diárias. Entretanto, é necessário ressaltar que existem fatores que tornam esse processo menos eficaz que o desejado, como é o caso da ritimicidade na secreção de insulina, conforme verificada por Picinato et al. (2002), cuja flutuação nem sempre é passível de se reproduzir em diabéticos que se utilizam apenas da terapia de reposição. Para maior elucidação dessa questão, um estudo brasileiro recente revelou que apenas $7,3 \%$ e $5,1 \%$ do total de 1.358 pacientes acometidos por diabetes mellitus tipo I ou tipo II, respectivamente, se enquadram nos padrões considerados ótimos para controle de pressão arterial, glicemia e lipidemia (BRAGA et al., 2013). 
De tal maneira, o tratamento para pacientes com diabetes tipo I envolve ainda o regime alimentar e a atividade física como fatores que auxiliam no controle da hiperglicemia e na melhoria da qualidade de vida do paciente diabético (DANEMAN, 2006).

\subsection{Melatonina e diabetes mellitus}

Processos metabólicos e ritmos biológicos exibem uma relação de interdependência considerável. Enquanto os primeiros são adaptados aos diferentes desafios inerentes aos momentos de claro e escuro do ciclo circadiano e ainda em relação às variações sazonais, como se observa pela relação entre as fases de vigília/alimentação e sono/jejum, os ritmos biológicos sofrem influência direta de possíveis alterações do metabolismo de um organismo (GREEN; TAKAHASHI; BASS, 2008). Essa relação pode também ser explorada quando analisamos o comprometimento da organização circadiana quanto a produção e secreção hormonais após ratos obesos terem sido submetidos a uma dieta hipercalórica, nos quais verifica-se uma alteração no ritmo diário da produção de certos hormônios, além de aumento na produção de corticosterona plasmática e de queda na melatonina pineal, aspectos bastante semelhantes aos evidenciados para mulheres com síndrome metabólica, ou ainda o prejuízo em parâmetros associados a qualidade do sono em indivíduos diabéticos tipo I sem controle glicêmico apropriado (BARONE, 2011; CANO et al., 2008; CORBALÁN-TUTAU et al., 2012).

Dessa forma, modificações envolvendo a síntese e secreção de melatonina, um dos grandes componentes do sistema de sinalização da ritmicidade circadiana dos seres vivos, em função de alterações do metabolismo energético, como é o caso do diabetes mellitus, podem ser observadas com naturalidade. Ainda, é importante ressaltar que tais ocorrências implicam também em uma série de mudanças que vão desde o padrão comportamental de um indivíduo até as bases moleculares de controle do sistema de relógio de um organismo, abrangendo alças de transcrição e tradução gênicas, modificação de atividade enzimática e secreção hormonal (GREEN; TAKAHASHI; BASS, 2008).

No campo da ação da melatonina no diabetes, encontramos dados variados na literatura mostrando que a melatonina reduziu a hiperglicemia e a hiperlipidemia em ratas diabéticas induzidas ao quadro por injeção de estreptozotocina (STZ) 
(MONTILLA et al., 1998). Outros registros mostram que não houve diminuição da hiperglicemia em ratos diabéticos por STZ e posteriormente tratados intraperitonealmente com melatonina (VURAL et al., 2001), embora outro estudo tenha mostrado que ratos diabéticos por STZ pré-tratados com melatonina apresentaram níveis hiperglicêmicos mais baixos do que os mesmos animais nãotratados (ABDEL-WAHAB; ABD-ALLAH, 2000).

Dados recentes revelaram que ratos diabéticos obesos da linhagem ZDF (Zucker Diabetic Fatty) que receberam melatonina em água pelo período de seis semanas apresentaram redução na hiperglicemia de jejum e na insulinemia, além de nomalizar outros parâmetros como a hiperleptinemia, a quantidade de ácidos graxos livres e a hipoadiponectinemia quando comparados a outros animais de mesma idade e linhagem sem suplementação (AGIL et al., 2012).

Os primeiros registros na literatura analisando os efeitos do diabetes experimental sobre a síntese e secreção de melatonina mostraram, tanto em ratos quanto em hamsters (CHAMPNEY et al., 1983), que o diabetes quimicamente induzido por estreptozotocina provoca redução na síntese e nos níveis circulantes de melatonina. Essa diminuição na produção de melatonina pela glândula pineal seria principalmente resultante de uma redução da atividade da HIOMT.

Por outro lado, outros dados apontam para a não interferência da insulina no metabolismo da glândula pineal e, portanto, na concentração de melatonina, conforme explica Champney et al. (1986).

Entretanto, foi evidenciado que no hamster a insulina aumenta a atividade da AANAT e não da HIOMT. Injeções com insulina tiveram como efeito o aumento da atividade enzimática da AANAT, assim como da concentração sérica de melatonina. (LYNCH et al., 1973, apud STEBELOVÁ et al., 2007). No mesmo ano, O'Brien et al. (1986) mostraram que pacientes diabéticos com evidência de neuropatia autonômica não apresentam o aumento noturno fisiológico da melatonina plasmática, que encontra-se também alterado em pacientes sem neuropatia aparente, provavelmente caracterizando um estado subclínico de denervação simpática, de acordo com os autores.

Dados mais recentes também apresentam certa controvérsia. Assim, Herichová et al. (2005) não encontraram diminuição na síntese pineal de melatonina em ratos Wistar após 7 dias de indução de diabetes com uma única dose de STZ (100 mg/kg). O mesmo grupo mostrou, em contrapartida, diminuição da síntese 
pineal da indolamina, com níveis normais de melatonina plasmática. Essa contradição com os dados anteriores foi explicada pelos autores como sendo relacionada ao desenvolvimento do quadro diabético. Esses autores evidenciaram também níveis diminuídos no pâncreas, rins e duodeno, em animais diabéticos 17 dias pós-indução com estreptozotocina (65 mg/kg) (STEBELOVÁ et al., 2007). Tal grupo ainda apresenta a associação entre a dessincronização dos ritmos circadianos e a condição de saúde de diabéticos com suas alterações metabólicas, o que pode ser explicado por falhas entre relógio central (núcleo supraquiasmático) e o periférico.

O trabalho de Tutunco et al. (2005) mostrou que pacientes diabéticos com neuropatia autonômica cardíaca apresentaram níveis plasmáticos de melatonina diminuídos em relação à pacientes controles e a diabéticos sem neuropatia. Estudo em pacientes jovens adultos com síndrome metabólica não mostrou diferença nos níveis plasmáticos de melatonina, nem no perfil da melatonina, quando comparados a jovens adultos controles (ROBEVA et al., 2006). Um trabalho recente avaliou uma queda na produção de melatonina em homens obesos diabéticos tipo II, achado possivelmente correlacionado com a baixa sensibilidade à insulina encontrada nesses pacientes quando comparados aos seus controles, homens obesos e não diabéticos (MANTELE et al., 2012).

Peschke et al. (2006) mostraram que ratos Goto Kakizaki espontaneamente diabéticos tipo 2 apresentam diminuição de melatonina plasmática e da atividade da AANAT, associada a níveis elevados tanto de glicemia quanto de insulinemia, quando comparados a ratos Wistar. O mesmo trabalho mostrou ainda que os níveis plasmáticos de melatonina em pacientes diabéticos tipo 2 estão diminuídos, em associação a níveis elevados de glicemia e a níveis não significativamente aumentados de insulinemia. O mesmo grupo (PESCHKE et al., 2008) encontrou elevação na melatonina plasmática de animais diabéticos tipo 1 tanto com 12 quanto com 51 semanas de idade, 6 semanas pós-indução com STZ, além de também observarem aumento no RNAm da AANAT, do receptor de insulina e do receptor $\beta 1$ adrenérgico em animais de ambas idades, e aumento do RNAm para HIOMT nos animais de 12 semanas. Estudos recentes de Peschke et al., 2012 encontraram o aumento no nível de catecolaminas como possível causa do aumento na melatonina atribuído ao DM tipo I em ratos Wistar diabéticos por STZ e de uma linhagem espontaneamente diabética tipo I conhecida como LEW.1AR-iddm, sendo que o 
mesmo raciocínio poderia ser aplicada ao verificado para a síntese da indolamina em organismos com DM tipo II. Nesse estudo, a administração de insulina aos ratos LEW.1AR-iddm foi capaz de reverter o aumento diurno verificado para a adrenalina e noradrenalina e consequentemente da síntese de melatonina.

Estudos do nosso grupo (AMARAL, 2009) se contrapõem aos achados citados anteriormente. Evidências sobre a redução na síntese de melatonina em ratos Wistar foram verificadas após 3 e 15 dias da indução do quadro por STZ e ainda em animais submetidos a microdiálise, em que foi observado o decurso temporal do padrão de síntese de melatonina em momentos anteriores e posteriores a instalação do diabetes em um mesmo indivíduo. Esse mesmo estudo revelou ainda alguns mecanismos associados a produção pineal de melatonina e que se mostraram alterados no organismo diabético. Dentre eles, destacam-se a queda na no conteúdo de AMPc da glândula pineal e na atividade da AANAT. Ainda, foi constatada redução no conteúdo proteico da AANAT e modificações na ritmicidade da expressão gênica do receptor $\beta_{1}$ e das enzimas TPH1 e HIOMT.

Ainda nesse contexto é importante ressaltar que 0 diabetes mellitus quimicamente induzido por STZ e efeitos da hiperglicemia em cultura não estão relacionados a danos à integridade do gânglio cervical superior, importante estrutura na via de controle neural associada a produção de melatonina (Schmidt et al., 2001; Semra et al., 2004). A condição da glândula pineal em ratos com DM tipo I foi avaliada por Tsai et al., 2008, os quais observaram uma redução no volume glandular relacionado a queda do diâmetro nuclear dos pinealócitos a partir da quarta semana da instalação do quadro diabético. É fundamental destacar que não foram registradas quedas na população celular da glândula ao longo do período analisado de 6 meses na condição diabética, aspecto acompanhado por um aumento no conteúdo proteico de serotonina. 


\section{JUSTIFICATIVA}

Em virtude da relevância apresentada pela melatonina para o metabolismo energético, assim como para o desenvolvimento e funcionamento adequados do organismo em relação a coordenação de eventos e homeostasia, especialmente no que tange ao quadro de diabetes mellitus, o presente estudo poderá contribuir para um melhor entendimento da dinâmica de eventos inerente ao organismo diabético tratado com insulina.

É válido ressaltar que a queda de melatonina em organismos diabéticos pode estar relacionada à gênese de algumas das disfunções observadas em pacientes com DM, como, por exemplo, a baixa capacidade de defesa anti-oxidante, uma vez que a indolamina apresenta alto poder redutor. A neuropatia desenvolvida por diabéticos pode, igualmente, estar ligada a menor quantidade do hormônio circulante, uma vez que seu papel neuroprotetor já foi considerado em estudos anteriores. 


\section{OBJETIVOS}

Assim, pretende-se verificar se a reposição insulínica em animais diabéticos insulino-dependentes é capaz de reverter o quadro de queda na síntese de melatonina e ainda em qual momento do tratamento esse fato ocorre, contribuindo para a elucidação dos dados contraditórios existentes na literatura. Além desse aspecto, objetiva-se esclarecer a contribuição relativa da hiperglicemia e/ou da hipoinsulinemia na produção de melatonina, investigando-se para tanto os mecanismos associados a esse processo. 


\section{MATERIAIS E MÉTODOS}

\subsection{Animais e Desenho Experimental}

Para a realização do experimento foram utilizados ratos albinos da linhagem Wistar. Estes foram mantidos em biotério com ciclo claro-escuro normal de $12 \mathrm{~h} / 12 \mathrm{~h}$ e temperatura controlada de $21 \pm 2{ }^{\circ} \mathrm{C}$ pelo período aproximado de duas semanas, para adequada adaptação ao ciclo, antes do início dos procedimentos experimentais. Durante todo o período de estudo, os animais receberam água e comida à vontade.

Os procedimentos ao longo do experimento estão de acordo com os Princípios Éticos de Experimentação Animal adotados pelo Colégio Brasileiro de Experimentação Animal (COBEA).

O experimento foi dividido em quatro blocos, os quais foram realizados entre Agosto de 2011 e Agosto de 2013.

Os animais foram pesados e distribuídos de maneira randômica em três grupos:

I) Animais controles, $n=145$;

II) Animais diabéticos, $n=153$;

III) Animais diabéticos tratados com insulina, $n=161$.

Os animais dos grupos II e III foram submetidos à indução do diabetes por injeção de estreptozotocina. O grupo I foi usado como controle dos experimentos.

A eutanásia dos animais ocorreu após 15 dias do início de cada bloco experimental em diferentes pontos ou ZTs (Zeitgeber Time), quais sejam ZT3, ZT6, ZT9, ZT12, ZT15, ZT18, ZT21 e ZT24. Durante o escotoperíodo (ZT12 a 24), a eutanásia foi realizado em ambiente iluminado por luz vermelha (filtro Kodak $1 \mathrm{~A}$ ) de intensidade controlada. A síntese de melatonina, a expressão gênica na glândula pineal, o conteúdo proteico e a atividade da AANAT, o nível de AMPc e a atividade da $\mathrm{Na}^{+} / \mathrm{K}^{+}$ATPase foram analisados a partir das glândulas pineais retiradas no momento da eutanásia e congeladas para posterior análise.

É válido ressaltar que o total de animais assinalado acima pode ser melhor interpretado se considerarmos que a cada um dos pontos ou ZTs indicados uma quantidade de 3 a 4 animais era utilizada em cada um dos 3 grupos experimentais. 
A aferição da glicemia no momento da eutanásia foi realizada utilizando-se o sangue do tronco do animal, através do glicosímetro Optium $X_{c e e d}{ }^{\circledR}$. Um dia antes da eutanásia foi mensurado o peso dos animais.

Ainda, destaca-se que o ZT constitui uma padronização dos horários do ciclo circadiano (ciclo claro-escuro, de 12h/12h). O ZT0 ou ZT24 indica transição do escuro para o claro (o início do claro) e o ZT12 a transição do claro para o escuro (o início do escuro), conforme ilustração a seguir:

Figura 4 - Padronização do ciclo circadiano.

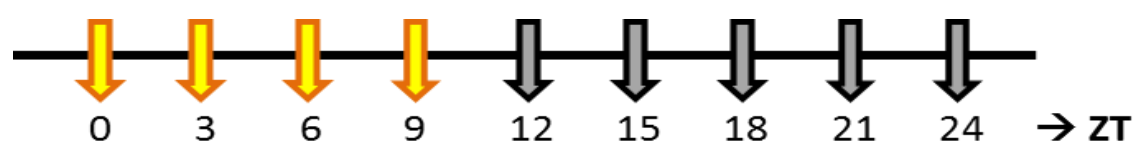

ZTs indicados em um intervalo de 3 horas ao longo de 24 horas diárias.

É importante salientar que os ZT24 e o ZT12 correspondem aos momentos indicados de transição independentemente do horário em que o biotério apaga ou acende suas luzes. Ainda, deve-se ressaltar que os animais eutanasiados no ZT12 continuaram sob a iluminação da fase clara no momento da eutanásia, enquanto aqueles eutanasiados no ZT24 foram mantidos em ambiente escuro iluminado por luz vermelha (filtro Kodak $1 \mathrm{~A}$ ).

\subsection{Indução de Diabetes por Estreptozotocina}

Os animais utilizados no experimento receberam uma dose de estreptozotocina (Sigma Chemical Co., St. Louis, MO, EUA), que resulta na ocorrência de diabetes mellitus do tipo 1 ou insulino-dependente, uma vez que leva a lesão das células $\beta$ das ilhotas pancreáticas por meio da cascata de eventos desencadeada pela alcalinização do DNA, conforme demonstrada por e Lenzen, 2008 e Schnedl et al., 1994. A estreptozotocina é uma molécula similar a glicose, fator que possibilita sua captação pelos transportadores GLUT 2 existentes na membrana das células $\beta$.

A estreptozotocina (Sigma Chemical Co., St. Louis, MO, EUA) foi preparada em tampão citrato de sódio $\left(\mathrm{NaCl} 0,9 \mathrm{~g}, \mathrm{H}_{2} \mathrm{O}\right.$ destilada $100 \mathrm{~mL}$, citrato de sódio 294 mg) $10 \mathrm{mM}$, pH 4,5. Foram administrados $60 \mathrm{mg} / \mathrm{Kg}$, intraperitonialmente, nos 
animais dos grupos II e III, no período de claro do dia zero de cada experimento. Deve-se ressaltar que nenhum animal estava em jejum no referido momento.

Foram considerados diabéticos aqueles que apresentaram a glicemia equivalente ou maior que $200 \mathrm{mg} / \mathrm{dL}$. Tal verificação ocorreu no dia seguinte à indução do quadro. Na mesma ocasião os indivíduos que não ficaram diabéticos sofreram nova indução. Uma nova medição foi realizada no dia posterior e mediante confirmação do quadro diabético os animais foram mantidos no experimento. Os animais que mesmo após a reindução não apresentaram alterações de glicemia para a constatação do DM tipo I foram retirados da experimentação.

A aferição foi realizada obtendo-se uma gota de sangue da cauda dos animais. A gota foi então colocada na tira reagente (Optium Blood Glucose Test Strips, Medisense ${ }^{\circledR}$, Bedford, MA, EUA) conectada ao glicosímetro Optium Xceed ${ }^{\circledR}$ (Medisense ${ }^{\circledR}$, Bedford, MA, EUA) que mensura a glicemia após 5 segundos de análise. $O$ aparelho foi previamente calibrado de acordo com as instruções do fabricante e a cada troca de lote de tiras reagentes.

Os animais do grupo controle receberam injeção intraperitoneal de tampão citrato de sódio, em quantidade condizente com sua massa corporal.

\subsection{Tratamento com Insulina}

Após a confirmação da instalação do quadro de diabetes, os animais do grupo III foram tratados por 12 dias com insulina subcutânea. A insulina foi administrada duas vezes ao dia, a saber: 2 unidades de insulina de ação prolongada (Glargina/Lantus $\AA^{\circledR}$,Sanofi Aventis, Alemanha) no começo do dia dos animais e uma mistura de 2 unidades de insulina de ação prolongada (Glargina/Lantus ${ }^{\circledR}$, Sanofi Aventis) e de 2 unidades de insulina regular (Humulin®, Lily, EUA ) no começo da noite.

\subsection{Dosagem de Melatonina por HPLC}

Para a determinação da melatonina foi empregado um sistema de Cromatografia Líquida Ultimate 3000 - Dionex (Sunnyvale, CA, EUA) composto por Bomba Quaternária, Injetor Automático com refrigeração de amostras, sistema de termostatização de colunas e detector eletroquímico Coulochem III composto de cela 
guarda 5020 e cela analítica amperométrica 5041 com eletrodo de carbono vítreo. O sistema foi controlado pelo software Chromeleon (Dionex, Sunnyvale, CA, EUA).

As glândulas pineais retiradas no momento da eutanásia e congeladas para posterior análise foram homogeneizadas separadamente em $60 \mu \mathrm{L}$ de tampão fosfato de sódio $(0,05 \mathrm{M}, \mathrm{pH} 7,9)$ preparado com a adição de um coquetel de inibidores de protease (Mini-complete livre de EDTA, Roche Applied Science, Indianápolis, IN, EUA). A homogeneização foi feita com o auxílio de um pistilo de plástico e com o tubo sempre no gelo para evitar a degradação das amostras. Com o objetivo de aperfeiçoar o uso das glândulas, alíquotas foram separadas e utilizadas para realização de mais de uma técnica com material proveniente da mesma pineal, sendo estas a dosagem de melatonina e a aferição radiométrica da atividade da AANAT.

Para dosagem de melatonina, $35 \mu \mathrm{L}$ de uma solução de ácido perclórico 0,1 M, 0,15 mM de EDTA $0,02 \%$ e metabissulfito de sódio $0,02 \%$ foram adicionados a $35 \mu \mathrm{L}$ do preparado com a glândula homogeneizada. Em seguida, as amostras foram centrifugadas por 2 minutos a $13.000 \mathrm{~g}$ (Eppendorf 5415C Centrifuge, Hamburg, Alemanha) e os sobrenadantes foram transferidos para placas de 96 poços para injeção no sistema de cromatografia. Como fase móvel foi usada uma solução contendo tampão acetato de sódio $0,1 \mathrm{M}$, ácido cítrico 0,1 M, EDTA 0,15 $\mathrm{mM}$ e metanol a $30 \%, \mathrm{pH} 3,7$. As cromatografias realizadas foram de fase reversa, o sistema foi operado isocraticamente com fase móvel com fluxo de $0,135 \mathrm{~mL} / \mathrm{min}$, potencial de oxidação de $+700 \mathrm{mV}$ e corrida com 10 minutos de duração.

As soluções-estoque do padrão de melatonina $(1 \mathrm{mM}$, Sigma Chemical Co., St. Louis, MO, EUA) foram preparadas em solução de $\mathrm{HCl}$ 0,1 $\mathrm{M}$ acrescida de EDTA 0,02\% e metabissulfito de sódio $0,02 \%$, e transferidas para tubos de microcentrífuga, sendo mantidas em congelador a $-80{ }^{\circ} \mathrm{C}$. No momento de sua utilização, uma amostra do padrão de melatonina foi descongelada e diluída em solução de ácido perclórico 0,1 M acrescido de EDTA 0,02\% e metabissulfito de sódio 0,02\% para obtenção das concentrações desejadas. Todos os reagentes utilizados possuíam grau de pureza adequado para HPLC.

Curvas de calibração com 7 concentrações diferentes e conhecidas $(0,145$ a $9,28 \mathrm{ng} / 40 \mu \mathrm{L}$ ) foram utilizadas para a quantificação da melatonina presente nas amostras. As curvas de calibração foram obtidas através do programa Chromeleon 
(Dionex, Sunnyvale, CA, EUA) pela relação das concentrações de cada padrão com as áreas dos picos correspondentes dos cromatogramas. A identificação da melatonina das amostras foi realizada pela comparação do seu tempo de retenção com aqueles dos padrões conhecidos e a quantificação obtida pelo mesmo programa computacional.

\subsection{Extração de RNA}

As glândulas pineais selecionadas para a verificação da expressão gênica foram inicialmente homogeneizadas em $70 \mu \mathrm{L}$ de tampão fosfato $(0,05 \mathrm{M}, \mathrm{pH} 7,9)$ de acordo com o procedimento descrito no item 4.4 - Dosagem de melatonina por HPLC. Do volume total obtido foram separadas 2 alíquotas de cada amostra, contendo $35 \mu \mathrm{L}$ cada, utilizadas posteriormente para a avaliação do conteúdo proteico da glândula e ainda para a obtenção do RNA da mesma conforme descrito a seguir.

As alíquotas com 0 conteúdo de $1 / 2$ pineal homogeneizada receberam inicialmente o reagente Trizol® $(800 \mu \mathrm{l}$, Invitrogen, Carlsbad, EUA) para extração do RNA total. A extração foi feita de acordo com as especificações do fabricante. Resumidamente, após adição do reagente e homogeneização, a mistura foi então incubada por 5 min à temperatura ambiente e acrescida de clorofórmio para desproteinização. O sobrenadante foi separado por centrifugação a 12000 g, 15 min, à $4 \stackrel{\circ}{\circ}$ e o RNA contido na fase aquosa foi precipitado com isopropanol e glicogênio (Roche Applied Science, Indianapolis, EUA), centrifugado (12000 g, $10 \mathrm{~min}, 4{ }^{\circ} \mathrm{C}$ ), lavado com etanol $75 \%$ e dissolvido com $\mathrm{H}_{2} \mathrm{O}$ deionizada previamente tratada com DEPC (dietilpirocarbonato). Previamente à utilização, uma amostra de cada extração foi quantificada e avaliada por espectrofotometria utilizando o aparelho NanoDrop ${ }^{\mathrm{TM}}$ 1000 (Thermo Scientific, Wilmington, EUA) que permite a análise de $1 \mu \mathrm{l}$ da amostra nos comprimentos de onda de 260 e $280 \mathrm{~nm}$, determinando sua concentração em $\mathrm{ng} / \mu \mathrm{l}$ e ainda fornecendo um parâmetro indicativo da qualidade do RNA extraído pela razão 260/280.

Assim, as amostras de RNA total obtidas foram tratadas com Turbo DNAfree $^{\mathrm{TM}}$ (Ambion, Austin, EUA) de acordo com as especificações do fabricante e foi procedida a quantificação utilizando o aparelho NanoDrop ${ }^{\mathrm{TM}} 1000$ (Thermo Scientific, Wilmington, EUA), de acordo com a descrição anterior. A seguir, as 
amostras contendo o RNA total foram armazenadas em -20 ำ até a utilização posterior.

\subsection{Obtenção de cDNA}

Amostras contendo $1 \mu \mathrm{g}$ de RNA total tratado com DNase foram submetidas à reação de transcrição reversa com primers randômicos. Para isto, foi adicionado a cada amostra o tampão da enzima, $\mathrm{MgCl}_{2}(25 \mathrm{mM})$, mistura de dNTPs (10 mM cada), primers randômicos (150 ng), e a enzima ImProm-Il Reverse Transcriptase (100U; Promega, Madison, EUA), em volume final de $20 \mu \mathrm{l}$. As reações foram realizadas com auxílio do termociclador por 5 min à $70^{\circ} \mathrm{C}$, seguidos de 15 min à 4 ${ }^{\circ} \mathrm{C}, 5$ min à $25^{\circ} \mathrm{C}$, com aquecimento para $42{ }^{\circ} \mathrm{C}$ por 60 min e $70 \stackrel{\circ}{ } \mathrm{C}$ por 15 min para desnaturação da enzima. Finalmente, as amostras de cDNA foram armazenadas à $20 \stackrel{\circ}{ } \mathrm{C}$.

\subsection{Análise quantitativa da expressão gênica por reação de PCR em tempo real}

A análise quantitativa da expressão gênica foi realizada através da técnica de PCR em tempo real utilizando o aparelho 7500 Fast $^{\mathrm{TM}}$ (Applied Biosystems, Foster City, EUA), de acordo com as especificações do fabricante. Os ensaios foram procedidos em duplicata utilizando cDNA (20 ng/ $\mu$ l) previamente sintetizado, adicionado à mistura da reação composta por SYBR Green mix (Invitrogen, Carlsbad, EUA) e 400 nM dos primers específicos para Tph 1 (NM_001100634), Aanat (NM_012818), Hiomt / Asmt (NM_144759.2), Adrb1 (NM_012701) e Adra1b (NM_016991) e para 3 constitutivos a saber: Rpl37a (NM_001108801.1), $\beta$-actina (NM_031144) e Actg1 (NM_001127449). Os parâmetros de amplificação foram os seguintes: uma etapa inicial de ativação da enzima a $95^{\circ} \mathrm{C}$ por 10 minutos, seguida de 40 ciclos que abrangeram a desnaturação a $95^{\circ} \mathrm{C}$ por $15 \mathrm{~s}$; anelamento dos primers a $63^{\circ} \mathrm{C}$ por 30 segundos e extensão a $72^{\circ} \mathrm{C}$ por 30 segundos. O número de cópias de cada gene foi estabelecido através da comparação do valor de amplificação de cada amostra com a curva de padrões composta de diluições de plasmídeos recombinantes que continha cDNA clonado dos genes de interesse e constitutivos ( $10^{7}$ a $10^{2}$ cópias). Após a determinação do número de cópias de cada gene, o valor obtido para os genes analisados foi normalizado pela média 
geométrica dos genes constitutivos, os quais não apresentaram variação em sua expressão ao longo do período e nos diferentes grupos analisados.

\subsection{Expressão proteica da AANAT}

O conteúdo proteico da glândula pineal foi avaliado a partir das alíquotas de $35 \mu \mathrm{L}$ obtidas com a homogeneização de glândulas pineais em $70 \mu \mathrm{L}$ de tampão fosfato $(0,05 \mathrm{M}, \mathrm{pH} 7,9)$, cuja parcela restante foi destinada à extração de RNA total conforme descrito anteriormente no item 4.5 - Extração de RNA. O homogenato foi submetido à centrifugação a $15000 \mathrm{~g}$ a $4 \stackrel{\circ}{\circ}$ por 20 min e o sobrenadante foi recolhido para posterior tratamento. As amostras receberam então $10 \mu \mathrm{L}$ de tampão Laemmli (Bio-Rad, Hercules, CA, EUA) adicionado de $\beta$-mercaptoetanol 10\% (Invitrogen, Carlsbad, CA, EUA) e glicerol 33\% (Invitrogen, Carlsbad, CA, EUA). A seguir, as amostras foram fervidas por 5 minutos a $97^{\circ} \mathrm{C}$, mantidas em gelo por 5 minutos e submetidas à eletroforese vertical, 100-190V por aproximadamente 3 horas a $4 \stackrel{\circ}{\circ}$, em gel de poliacrilamida a 14\%. Além das amostras, os géis contavam com um marcador de peso molecular Kaleidoscope (Bio-Rad, Hercules, CA, EUA) e com um pool proteico constituído de glândulas pineais. A transferência das proteínas separadas no gel foi feita eletricamente para uma membrana de nitrocelulose através de um aparelho semi-dry (Bio-Rad, Hercules, CA, EUA) por 75 min a 15 V. A ligação inespecífica de proteínas na membrana de nitrocelulose foi diminuída pela incubação destas com tampão de bloqueio (Blocking Buffer Odyssey, LI-COR Biosciences, Lincoln, NE, EUA) à temperatura ambiente e mantido sob agitação durante 2 horas. Estas membranas foram então lavadas por 3 vezes de 10 minutos cada utilizando tampão basal (Tris 10 mM, NaCl $150 \mathrm{mM}$ e Tween 20 0,02\%) e então incubadas por cerca de 12 a 14 horas (overnight) com anticorpos primários anti-AANAT (diluição 1:10.000 em tampão basal) sob agitação. A seguir, foi realizado o mesmo procedimento de lavagem com tampão basal e assim as membranas foram incubadas por 1 hora a temperatura ambiente sob agitação com anticorpos secundários IRDye 800 anti-IgG de camundongo para AANAT (Molecular Probes, Eugene, OR, EUA). O procedimento de incubação overnight com anticorpos primários anti- $\beta$-actina foi repetido ao final do dia, seguindo então, após a lavagem das membranas, a incubação com anticorpos secundários Alexa Fluor 680 anti IgG de coelho para $\beta$-actina (Molecular Probes, Eugene, OR, EUA). Esses anticorpos 
foram diluídos 1:10.000 em tampão basal. Finalmente, as membranas foram lavadas por 3 vezes de 10 minutos a temperatura ambiente e sob agitação conforme descrito anteriormente.

A visualização das membranas foi realizada utilizando o aparelho Odyssey ${ }^{\circledR}$ (Odyssey® Infrared Image System, LI-COR Biosciences, Lincoln, NE, EUA) que permite a detecção direta de fluorescência por infravermelho, aumentando a acurácia e a sensibilidade. As imagens foram analisadas e quantificadas utilizando o software Odyssey 3.0 (LI-COR Biosciences, Lincoln, NE, EUA). A quantificação da AANAT foi normalizada pela quantificação da $\beta$-actina. $O$ tamanho da proteína foi estimado por comparação com marcadores padrão de peso molecular.

\subsection{Análise Radiométrica da Atividade Enzimática da AANAT}

Para o ensaio de atividade da AANAT foram utilizados $25 \mu \mathrm{L}$ provenientes das alíquotas dos preparados homogeneizados da glândula pineal destinados a dosagem de melatonina por HPLC.

Tal técnica baseia-se na quantificação da $\mathrm{N}-\left[{ }^{3} \mathrm{H}\right]$-acetiltriptamina que é o produto da reação da $\left[{ }^{3} \mathrm{H}\right]$ acetil-coenzima $A\left(\left[{ }^{3} \mathrm{H}\right]\right.$ acetil $\left.\mathrm{CoA}\right)$ e da triptamina, catalizada pela enzima arilalquilamina- $\mathrm{N}$-acetiltransferase. $\mathrm{O}$ produto marcado foi extraído em clorofórmio e sua radioatividade foi medida [método desenvolvido por (PARFITT et al., 1976), modificado a partir do método de (DEGUCHI e AXELROD, 1972)].

Os procedimentos consistiram em adicionar aos tubos de microcentrífuga contendo o preparado homogeneizado da glândula: $25 \mu \mathrm{L}$ de triptamina (40 mM), 25 $\mu \mathrm{L}$ de $\left[{ }^{3} \mathrm{H}\right]$ acetilCoA (2 mM, Amersham Biosciences, Piscataway, NJ, EUA) e $25 \mu \mathrm{l}$ de acetilCoA (1 mM), a $4 \stackrel{\circ}{\circ}$.

As amostras foram agitadas e incubadas em banho seco (Eppendorf Thermomixer, Hamburg, Alemanha) com agitação de $650 \mathrm{rpm}$, a $37 \stackrel{\circ}{\circ} \mathrm{C}$, por 20 minutos. A reação foi interrompida pela adição de $1 \mathrm{~mL}$ de clorofórmio saturado com tampão fosfato a cada uma das amostras e o produto foi extraído agitando-se os tubos por 1 minuto. Para a separação completa das fases aquosas e lipossolúveis as amostras foram centrifugadas (Eppendorf 5804R Centrifuge, Hamburg, Alemanha) por 40 segundos, a $14.000 \mathrm{rpm}$, a $4 \stackrel{\circ}{\circ}$. 
As fases aquosas foram removidas e $200 \mu \mathrm{L}$ do clorofórmio saturado com tampão fosfato foram acrescentados ao restante. Novamente as amostras foram agitadas, centrifugadas e as fases aquosas removidas. Para finalizar, $500 \mu \mathrm{L}$ do clorofórmio contendo o produto da reação ( ${ }^{3} \mathrm{H}-\mathrm{N}$-acetiltriptamina) foram transferidos para os tubos de contagem e evaporados até que as amostras ficassem completamente secas. O líquido de cintilação ( $3 \mathrm{~mL}$, BCS-NA non-aqueous biodegradable counting scintillant, Amersham Biosciences, Piscataway, NJ, EUA) foi acrescentado e a radioatividade de amostras e tubos de "branco" (mistura dos reagentes, com exceção do preparado de glândula pineal homogeneizada) foi medida em contador $\beta$ (LS 6500 Liquid Scintillation Counter, Beckman Coulter Inc., Fullerton, CA, USA). Os resultados foram expressos em picomoles de produto formado por glândula por hora.

Os reagentes não-radioativos usados nesse ensaio foram comprados da Sigma Chemical Co. (St. Louis, MO, EUA).

\subsection{Quantificação do AMP cíclico}

O conteúdo de AMPc foi quantificado por ELISA usando o cAMP direct immunoassay kit (BioVision, Mountain View, CA, EUA). Na preparação das amostras, cada pineal foi homogeneizada em $100 \mu \mathrm{L}$ de $\mathrm{HCL} 0.1 \mathrm{M}$, centrifugada por 5 minutos e o sobrenadante coletado. A partir desse ponto os procedimentos forma feitos de acordo com as recomendações do fabricante. Resumidamente o kit baseiase em um ensaio de competição, sendo que a placa fornecida apresenta o anticorpo policlonal anti-AMPc ancorado através da proteína G recombinante. O AMPc conjugado com peroxidase de raiz forte (cAMP-HRP) compete diretamente com o AMPc oriundo das amostras pela ligação no anticorpo presente na placa. Após períodos de incubação e procedimentos de lavagens, o substrato colorimétrico da HRP foi adicionado tornando possível a quantificação do montante de cAMP-HRP ligado na placa. A leitura foi feita no comprimento de onda de $450 \mathrm{~nm}$, sendo a intensidade inversamente proporcional a concentração de AMPc proveniente da amostra. Uma curva padrão com quantidades conhecidas de AMPc foi elaborada, permitindo a quantificação das amostras, cujos resultados foram expressos em pmol/pineal. É importante destacar que a quantificação do AMPc apresentada 
adiante nos resultados representa uma média dos ZTs 12,3; 13; 13,15; 13,30 e 13,45 , ou seja, momento em que a variação desse mensageiro intracelular foi mais pronunciada e ainda diretamente relacionada a ativação da enzima AANAT de acordo com variados estudos das décadas de 70 e 80 anteriormente citados e dados prévios do nosso laboratório.

\subsection{Microdiálise da Glândula Pineal}

Além dos animais componentes dos grupos independentes citados anteriormente, a técnica de microdiálise foi realizada em um único animal com o objetivo de verificar a dinâmica das alterações ocorridas na síntese de melatonina pineal em diferentes condições do animal, quais sejam:

- condição de controle;

- condição de controle (animal normoglicêmico) com injeção intra-pineal de glicose a $500 \mathrm{mg} / \mathrm{dL}$, valor costumeiramente verificado em ratos diabéticos;

- condição de diabético (glicemia superior a $200 \mathrm{mg} / \mathrm{dL}$, sendo o quadro diabético induzido por estreptozotocina a $60 \mathrm{mg} / \mathrm{Kg}$, conforme protocolo citado anteriormente no tópico 4.2);

- condição de diabético tratado com insulina (seguindo o mesmo protocolo de tratamento oferecido ao grupo III, conforme protocolo citado anteriormente no tópico 4.3).

A avaliação de síntese da melatonina pineal é possível graças a implantação de uma sonda diretamente na pineal do rato, permitindo a coleta a cada hora do período do escuro, momento de produção da melatonina pelo organismo. O uso dessa técnica permite a avaliação de parâmetros do mesmo animal tanto em condições fisiológicas quanto em condições experimentais.

As etapas que antecedem o período de coleta horária das amostras do rato consistem em:

\section{- Confecção das sondas:}

Processo manual que abrange os seguintes passos:

1) Corte das agulhas $23 G \times 1$ " (Nipro Medical Ltda, Sorocaba, SP, Brasil) para separação da base plástica. O bisel foi polido utilizando-se uma lixa acoplada ao Dremel MultiPro (DREMEL ${ }^{\circledR}$, Racine, WI, EUA). O mesmo aparelho foi usado para 
arredondar as pontas da agulha, formando conectores de inox que facilitam a posterior conexão com a sonda e/ou cânulas de polipropileno.

2) Polimento e limpeza dos conectores de inox com o auxílio de um pedaço de fio de tungstênio.

3) Soldagem do conector de inox, com auxílio de uma gota de ácido fosfórico e ferro de solda, previamente enrolado com um pedaço de fio de latão (Morelli ${ }^{\circledR}$ Ortodontia, Sorocaba, SP, Brasil) em seu 1/3.

4) Lavagem os conectores com água e álcool, seguida de injeção de ar para retirada de qualquer resto de líquido de dentro dos conectores

5) Estiramento de pedaços de fio de tungstênio $\left(\varnothing=100 \mu \mathrm{m}, \mathrm{GE}^{\circledR}\right.$, Fairfield, CT, EUA) com aproximadamente $6,0 \mathrm{~cm}$ de comprimento. A ponta deve ser afinada e centralizada em uma das extremidades do fio.

6) Corte da membrana $\left(\varnothing i=150 \mu \mathrm{m}, \varnothing e=170 \mu \mathrm{m},{\text { Spectra} / \text { Por }^{\circledR}}^{\circledR}\right.$, Spectrum $^{\circledR}$, Gardena, CA, USA) em pedaços de $7,0 \mathrm{~cm}$. É importante destacar que a seletividade de peso molecular da membrana é de até $13 \mathrm{kDa}$.

7) Introdução do fio de tungstênio na membrana, usando lupa para evitar rupturas. A extremidade sem ponta do fio deve ficar para fora da membrana para servir de apoio.

8) Introdução do conjunto no conector de inox e deixar a extremidade do fio para fora do mesmo. A junção do inox deve ser colada com a membrana usando adesivo Epóxi (Araldite ${ }^{\circledR}$, Taboão da Serra, SP, Brasil), após o que deve-se aguardar o tempo recomendado de secagem.

9) O comprimento da membrana deve ser marcado para delimitar os $2 \mathrm{~mm}$ que ficam descobertos, possibilitando a diálise. O resto da membrana deve ser isolado com silicone neutro (Sil Trade ${ }^{\circledR}$, Várzea Paulista, SP, Brasil).

10) A membrana sobressalente deve ser cortada para expor a ponta do fio. Colar membrana no fio utilizando Adesivo Instantâneo Universal (Super Bonder ${ }^{\circledR}$, Loctite/Henkel, São Paulo, SP, Brasil).

\section{- Implantação da sonda:}

Os procedimentos de implantação de sonda, montagem do sistema e verificação por histologia seguem a descrição feita por Skorupa et al. (2003), com algumas modificações. Ratos albinos Wistar com peso entre 250 e $280 \mathrm{~g}$ foram colocados em biotério com temperatura controlada e ciclo invertido com $12 \mathrm{~h}$ de claro e $12 \mathrm{~h}$ de escuro (luzes acesas às $21 \mathrm{~h}$ ) três semanas antes da cirurgia. Os animais 
foram anestesiados com uma mistura de Anasedan ${ }^{\circledR}$, Vetbrands, Brasil e Dopalen ${ }^{\circledR}$, Vetbrands, Brasil intraperitoneal $(0,15 \mathrm{~mL} / 100 \mathrm{~g})$, posicionados no aparelho estereotáxico (David Kopf Instruments, Tujunga, CA, EUA) e horizontalizados. A sonda foi fixada num suporte adaptado à torre do aparelho e horizontalizada.

Sabendo-se que a pineal situa-se logo abaixo e um pouco anterior ao ponto de referência lambda $(\lambda)$, uma abertura foi feita em cada lado do osso temporal de modo que a sonda pudesse ser implantada transversalmente com a zona de troca (2 $\mathrm{mm}$ ) posicionada $0,7 \mathrm{~mm}$ à frente do $\lambda$ e $1,6 \mathrm{~mm}$ abaixo da calota craniana. Uma vez a sonda implantada, outro tubo de inox foi colado à extremidade livre da membrana e em seguida o fio de tungstênio foi retirado. As duas extremidades da sonda (entrada e saída) foram fixadas na superfície do crânio com cimento dentário (copolímero de acrílico e acrílico auto-polimerizante, Clássico Artigos Odontológicos ${ }^{\circledR}$, São Paulo, SP, Brasil).

Após a fixação da entrada e saída, procedeu-se a sutura e o teste manual para checagem da sonda. $O$ teste consistiu em injetação cuidadosa da solução de Ringer ( $\mathrm{NaCl} 63 \mathrm{mM}, \mathrm{KCl} 4 \mathrm{mM}, \mathrm{CaCl} 21,2 \mathrm{mM}, \mathrm{MgCl} 21 \mathrm{mM}$, Hepes $10 \mathrm{mM}$ ) na extremidade de entrada da sonda com atenção em se observar eventual vazamento/entupimento e se a gota da solução extravasava no extremidade de saída. Os animais cujas sondas responderam positivamente ao teste manual foram mantidos no experimento, o que correspondeu a um único rato.

Os ratos permaneceram em observação por 3 dias antes do início da experimentação, acondicionados em caixas individuais com ração e água à vontade.

\section{- Montagem e coleta das amostras:}

Uma hora antes do início da coleta das amostras, a entrada de cada uma das sondas foi conectada a uma bomba de perfusão (PHD 22/2000, Harvard Apparatus, Madras, OR, EUA) através de um cateter de polietileno $(\varnothing \mathrm{i}=0,38 \mathrm{~mm}, \varnothing \mathrm{e}=1,09$ $\mathrm{mm}$, Portex Limited, Hythe, Kent, Inglaterra) via um sistema de juntas giratórias com braço móvel (Instech Laboratories, Plymouth Meeting, PA, EUA, Fi). O mesmo sistema foi utilizado para conectar a saída das sondas, através de cateter de polietileno, a um tubo de coleta de polipropileno (Amersham Biosciences, Piscataway, NJ, EUA).

O conjunto de cateteres passa ao longo de um túnel articulado de malha metálica, conectado à junta giratória. Este sistema é associado a um balanceador que permite a livre movimentação dos animais. Durante todo o período de diálise, as 
glândulas pineais dos animais foram perfundidas com uma solução de Ringer num fluxo de $3 \mu \mathrm{L} / \mathrm{min}$.

As amostras do dialisado foram coletadas a cada hora durante todo o período de escuro, uma amostra foi coletada do ZT0 ao ZT10 (fotoperíodo) e uma foi coletada do ZT10 ao ZT12. Todas as amostras foram conservadas a $-20^{\circ} \mathrm{C}$ para posterior dosagem de melatonina.

\section{- Verificação da implantação da sonda:}

Após o término das coletas o rato foi eutanasiado por excesso de anestésico e posterior decapitação. A cabeça foi mantida em formalina para fixação e facilitação da obtenção dos cortes histológicos. O cérebro foi retirado delicadamente, de modo que a sonda permanecesse no lugar, e mantido novamente na formalina. Cortes sagitais com $30 \mu \mathrm{m}$ de espessura foram feitos em criostato na região da glândula pineal. Os cortes foram colocados em lâminas gelatinadas para posterior coloração com tionina (coloração de Nissl) e análise sob microscópio. Os resultados da microdiálise foram validados ou não conforme a qualidade da implantação das sondas.

\subsection{Dissociação celular da glândula pineal e cultura de suas células isoladas}

Glândulas pineais foram obtidas a partir de ratos controles, diabéticos e diabéticos tratados com insulina da linhagem Wistar com peso entre 180-200 g, eutanasiados por decapitação. Após a retirada das glândulas, essas foram armazenadas em tubos de centrífuga contendo meio de cultura DMEM (Gibco, Grand Island, NE, EUA), mantido em gelo, formando pools correspondentes aos grupos experimentais.

A seguir, foi procedida a dissociação enzimática feita com o kit de digestão proteolítica com papaína (Papain Dissociation System, Worthington Biochemical Corporation, Freehold, NJ, EUA), sempre sob fluxo laminar. Os reagentes do kit foram preparados de acordo com as orientações do fabricante. As glândulas foram picotadas com uma tesoura cirúrgica e colocadas na solução enzimática, cujo pH foi equilibrado com 95\% O2 e 5\% CO2, e incubadas em banho úmido (Microprocessed Controlled Water Baths, Polyscience, Niles, IL, EUA) com agitação plana (cerca 100 ciclos por minuto) a $37^{\circ} \mathrm{C}$ por 40 minutos. 
Ao final da incubação o tecido foi dissociado mecanicamente usando-se uma pipeta Pasteur e a proteólise foi interrompida pela adição de ovomucóide. As células foram precipitadas por centrifugação (Eppendorf 5804R Centrifuge, Hamburg, Alemanha) a $300 \mathrm{~g}$ por 5 minutos a uma temperatura de $20 \stackrel{\circ}{\circ}$, em um gradiente gerado pela mistura de EBSS, ovomucóide e DNAse. O sobrenadante foi desprezado e o pellet ressuspendido em $1 \mathrm{~mL}$ de meio DMEM (Gibco, Grand Island, NE, EUA), resultando em $2 \times 10^{5}$ células ( 85 a $90 \%$ de pinealócitos e 10 a $15 \%$ de astrócitos) por glândula.

As células de animais controles, diabéticos e diabéticos tratados com insulina foram distribuídas em dois grandes grupos: o primeiro com células incubadas em meio com concentração baixa de glicose (equivalente a $100 \mathrm{mg} / \mathrm{dL}$ ) e o segundo com alta concentração de glicose no meio (equivalente a $500 \mathrm{mg} / \mathrm{dL}$ ). É importante destacar que tal valor - $500 \mathrm{mg} / \mathrm{dL}$ - costuma ser encontrado após a indução de diabetes por STZ em ratos. A placa contendo essas células foi levada a estufa e mantida em repouso por 1 hora. Após esse período, a placa foi retirada e as células de animais controles, de ambos os grupos acima descritos (100 e $500 \mathrm{mg} / \mathrm{dL}$ ) foram submetidas à estimulação por noradrenalina obedecendo a uma curva dose $x$ efeito com as concentrações de $10^{-9} \mathrm{M}$ até $10^{-6} \mathrm{M}$. As células provenientes de pineais de animais diabéticos e diabéticos tratados com insulina receberam apenas noradrenalina na concentração de $10^{-4} \mathrm{M}$. A seguir, as placas retornaram a estufa para incubação por cinco horas, após o que as células foram congeladas para posterior dosagem de melatonina por HPLC.

\subsection{Atividade da $\mathrm{Na}^{+} / \mathrm{K}^{+}$ATPase pineal}

A avaliação da atividade enzimática da $\mathrm{Na}+/ \mathrm{K}+$ ATPase se deu por quantificação colorimétrica por espectrofotometria através da detecção de moléculas de fosfato, oriundas da hidrólise do ATP e complexadas com molibdato de amônio, detectadas na faixa de $690 \mathrm{~nm}$, de acordo com a técnica adaptada a partir de Feschenko e Sweadner, 1994.

Ratos da linhagem Wistar, controles e diabéticos e diabéticos tratados com insulina, foram eutanasiados durante o escotoperíodo para obtenção de glândulas pineais que foram imediatamente congelas e armazenadas para os testes posteriores. 
As glândulas foram então colocadas em $60 \mu \mathrm{L}$ de tampão NOS (320 mM Sacarose, 20 mM HEPES e $1 \mathrm{mM}$ EDTA, pH 7,4) acrescido de inibidor de protease PMSF (1mM) e submetidas a sonicação (5 pulsos com duração de 5 segundos cada). O homegenato foi centrifugado a $14.000 \mathrm{~g}$ por 2 minutos a $4 \stackrel{\circ}{\circ} \mathrm{C}$, recolhendose o sobrenadante em um novo tubo. A seguir, foi procedida a dosagem de proteínas por Bradford.

A partir da dosagem proteica foram selecionados $40 \mu \mathrm{L}$ das amostras, contendo $10 \mu \mathrm{g}$ de proteína, destinados para a verificação da atividade da $\mathrm{Na}^{+} / \mathrm{K}^{+}$ ATPase. As amostras foram dividas em dois grupos em que $120 \mu \mathrm{L}$ de ouabaína (10 $\mathrm{mM}$ ), substância inibidora da $\mathrm{Na}^{+} / \mathrm{K}^{+}$ATPase, esteve presente ou ausente, sendo nesse caso substituída por $120 \mu \mathrm{L}$ de água MilliQ. Ainda, cada amostra foi acrescida de $200 \mu \mathrm{L}$ de tampão histina ( $\mathrm{pH}$ 7,2) e $40 \mu \mathrm{L}$ de ATP $(30 \mathrm{mM}$ ). Passados 20 minutos de reação a $37{ }^{\circ} \mathrm{C}$ em constante agitação, foram adicionados $600 \mu \mathrm{L}$ da solução de Quenching ( $10 \mathrm{~N} \mathrm{H}_{2} \mathrm{SO}_{4}$ e $5 \%$ molibdato de amônio) para o término da mesma, sendo as amostras colocadas imediatamente em gelo. Finalmente, $20 \mu \mathrm{L} d a$ solução de Fiske (Sigma-Aldrich, Saint-Louis, MO, EUA) foram distribuídos nas amostras. Após 30 minutos foi feita a leitura em espectrofotômetro. Os mesmo passos foram realizados para a curva padrão, contendo tampão histidina (140 mM $\mathrm{NaCl}, 20 \mathrm{mM} \mathrm{KCl}, 3 \mathrm{mM} \mathrm{MgCl} 26 \mathrm{H}_{2} \mathrm{O}, 3 \mathrm{mM}$ ATP e $30 \mathrm{mM}$ Histidina), água MilliQ e solução padrão de hidrogenofosfato de potássio a $10 \mathrm{mM}$.

De tal maneira a atividade da $\mathrm{Na}^{+} / \mathrm{K}^{+}$ATPase em si equivale a subtração da parcela insensível à ouabaína da parcela que conservou a atividade total.

\subsection{Metodologia de Análise de Resultados}

As análises estatísticas, escolhidas de acordo com o desenho experimental, foram realizadas utilizando-se o programa computacional Prism v 5.01 (GraphPad Software Inc., San Diego, CA, EUA). Procederam-se os testes de análise de variância (ANOVA) uni ou bifatorial, seguido do teste de comparação múltipla de Bonferroni. Os resultados foram considerados estatisticamente diferentes para $\mathrm{p}<0,05$. 


\section{RESULTADOS}

\subsection{Peso}

Os animais foram pesados em quatro momentos ao longo do experimento. As duas primeiras pesagens serviram para a esquematização do bloco experimental, de forma a se identificar o melhor momento para a indução do diabetes, uma vez que os animais deviam apresentar um peso médio de $250 \mathrm{~g}$ para tanto. A terceira pesagem foi realizada no dia anterior à indução, permitindo assim o cálculo do volume da droga a ser administrada no dia 0 . Por fim, no dia 15 os animais foram novamente pesados.

Com os dados obtidos foi verificada a diferença entre o peso no dia 0 e 0 peso no dia 15. A diferença ou delta $(\Delta)$ permitiu a construção de um gráfico com o delta do peso, conforme apresentado na Figura 5 localizada a seguir.

Figura 5 - Delta do peso.

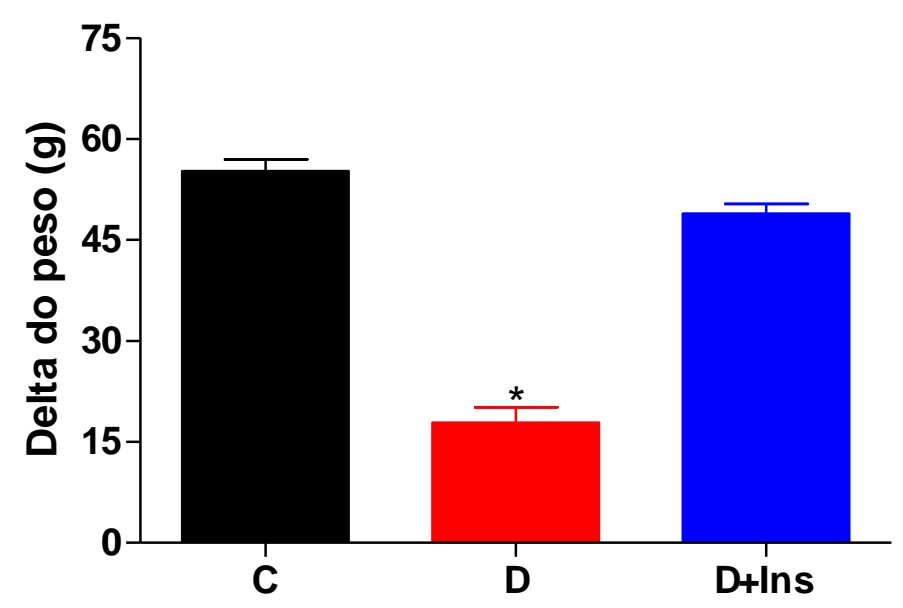

O delta do peso foi avaliado a partir da diferença verificada entre os dias 0 e 15 para os grupos diabético ( $D, n=94)$, controle $(C, n=89)$ e diabético tratado com insulina ( $D+1 n s, n=97)$. ANOVA unifatorial seguida de Bonferroni $\operatorname{com}^{*} p<0,05$ vs $C$ e $D+$ Ins.

Foi possível perceber que os animais pertencentes ao grupo dos diabéticos não tratados engordaram menos $(\Delta=17,8 \mathrm{~g} \pm 2,2)$ quando comparados aos demais grupos, os quais revelaram claro ganho de peso ao longo dos 15 dias de experimento, sendo que o grupo controle apresentou $\Delta=55,2 \mathrm{~g} \pm 1,7$ e $\circ$ grupo diabético tratado teve variação de peso equivalente a $48,9 \mathrm{~g} \pm 1,3$. 


\subsection{Glicemia}

A glicemia dos animais foi avaliada em três momentos. O primeiro deles ocorreu um dia após a indução do diabetes, para a constatação da instalação de tal condição e identificação dos animais com glicemia inferior a $200 \mathrm{mg} / \mathrm{dL}$, que receberam a reinjeção de STZ. O segundo momento corresponde ao dia seguinte à reindução, para o estabelecimento da permanência dos animais diabéticos e retirada daqueles que não se enquadravam. Por fim, a última aferição glicêmica foi realizada no momento da eutanásia, a partir do sangue do tronco dos animais.

A Figura 6 representa a glicemia média no dia 15 de todos os grupos experimentais.

Figura 6 - Média da glicemia.

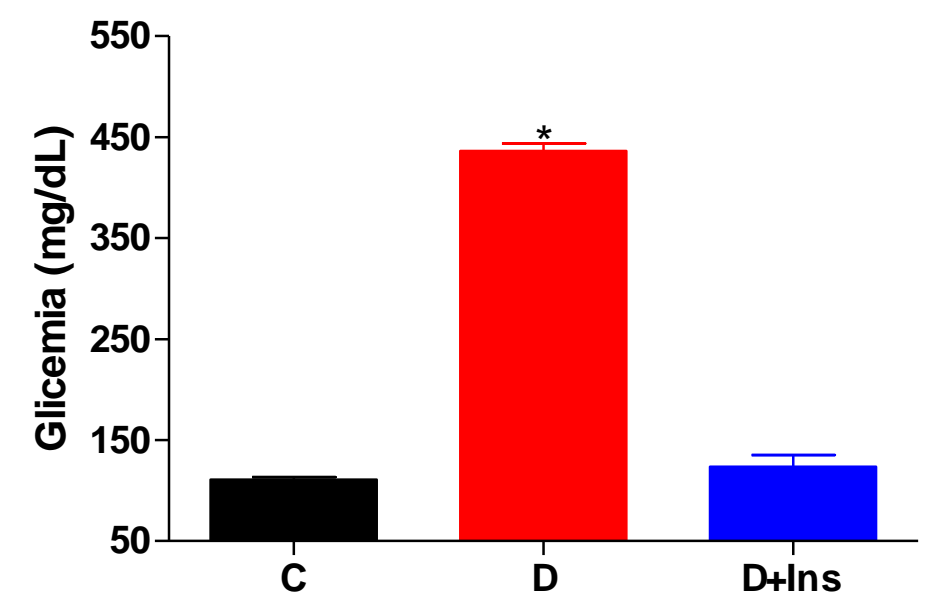

Média glicêmica do dia 15 para animais do grupo controle $(C, n=89)$, diabético $(D, n=94)$ e tratado com insulina ( $D+$ Ins, $n=97$ ). ANOVA unifatorial seguida de Bonferroni com * $p<0,05$ vs $C$ e $D+$ Ins.

A glicemia média do grupo de diabéticos tratados com insulina indica que 0 hormônio foi eficaz em reverter esse aspecto do quadro diabético, normalizando a glicemia, que não apresentou diferença significativa em comparação ao grupo controle. Por outro lado, o grupo dos diabéticos revelou altos níveis glicêmicos. Em algumas ocasiões o registro do glicosímetro apontava para uma glicemia "High", o que foi considerado, para efeito de análise, equivalente a $500 \mathrm{mg} / \mathrm{dL}$, limite máximo de detecção, de acordo com as informações fornecidas pela fabricante do aparelho. 


\subsection{Melatonina}

A melatonina foi analisada a partir das glândulas retiradas dos animais no momento da eutanásia e congeladas para posterior análise. Os dados obtidos com a análise por HPLC são apresentados na Figura 7 a seguir.

Figura 7 - Perfil da melatonina ao longo do escotoperíodo.

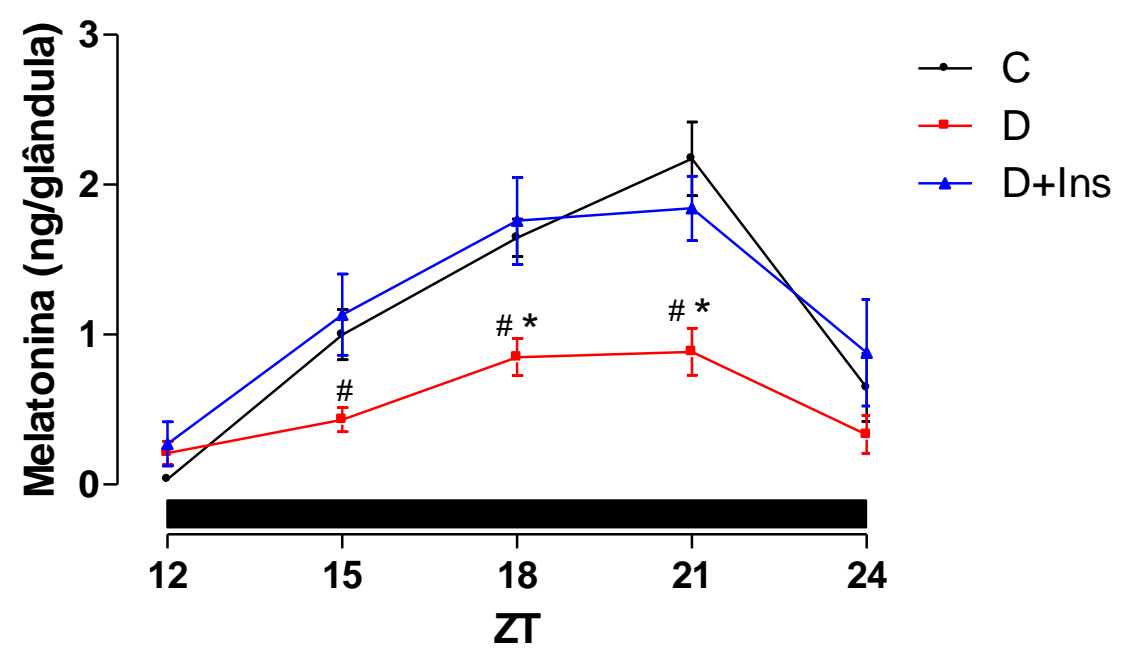

Os 5 ZTs analisados correspondem ao escotoperíodo, representado pela barra em preto. O ZT 12 equivale ao início do período do escuro, enquanto o ZT 24 representa a transição do escuro para o claro. Notar que para todos os grupos o pico na síntese de melatonina ocorre por volta dos ZTs $18 \mathrm{e}$ 21 ( $C n=23, D n=38$ e $D+\operatorname{lns} n=39$ ). ANOVA bifatorial seguida de Bonferroni com $p<0,0001$ para 0 fator tratamento; $p<0,0001$ para o fator $Z T$ e $p=0,2134$ para a interação tratamento $\times Z T$. ${ }^{*} p<0,05$ vs $C$ e $D+\operatorname{lns} . \# p<0,05$ vs $D+$ Ins.

O grupo diabético não tratado apresenta ao longo de todos os ZTs estudados redução na síntese de melatonina em relação aos grupos controle e diabético tratado com insulina. Tal diferença torna-se significativa no momento que representa o pico na síntese da indolamina (entre os ZTs 18 e 21), ou seja, no meio da noite. É importante observar que o grupo diabético tratado com insulina e o grupo controle não revelam diferenças quanto ao conteúdo de melatonina, o que indica reversão da queda na síntese de melatonina mediante o tratamento do diabetes com insulina. 


\subsection{Expressão gênica na glândula pineal}

A expressão gênica das três principais enzimas presentes na via de síntese da melatonina na glândula pineal, assim como dos dois adrenoceptores envolvidos nesse mecanismo foi avaliada por PCR em tempo real ao longo de 24 horas, abrangendo as fases clara e escura, em intervalos de 3 horas, obtendo-se assim o ritmo diário do RNAm desses 5 genes na glândula pineal para os três grupos em estudo como verificado a seguir.

Figura 8 - Perfil da expressão gênica na glândula pineal.
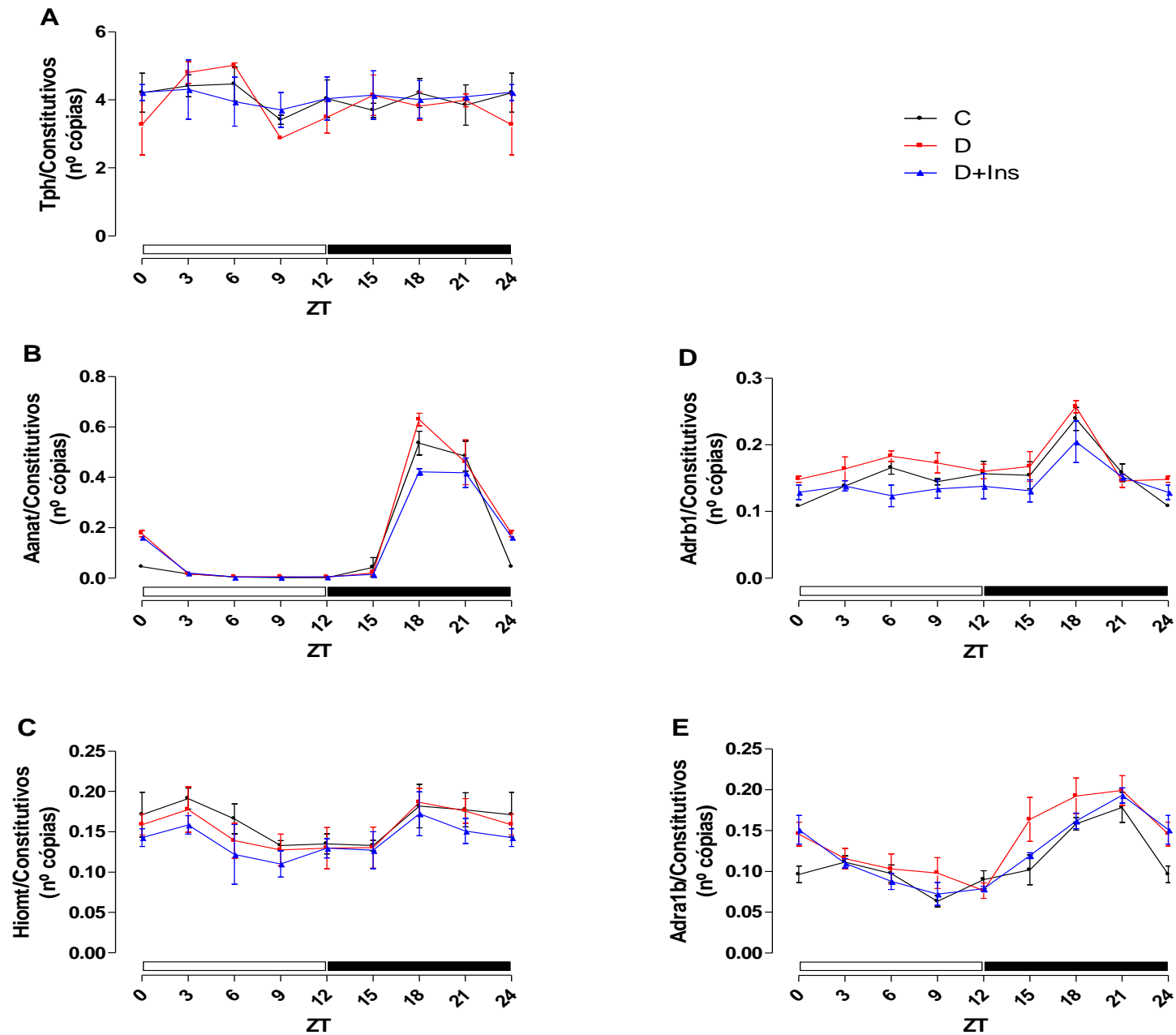

A expressão gênica das enzimas triptofano hidroxilase (Tph1) (A), arilalquilamina-N-acetiltransferase (Aanat) (B) e hidroxindol-oxi-metiltransferase (Hiomt) (C) na glândula pineal ao longo de 24 horas estão representadas pelos gráficos localizados à esquerda. Nos gráficos à direita estão representadas as expressões gênicas dos adrenoceptores $\beta$ e $\alpha$, respectivamente Adrb1 (D) e Adra1b (E). A barra acima do eixo horizontal representa a fase clara e a fase escura do ciclo de iluminação ao qual estavam submetidos os animais controles (C), diabéticos (D) e diabéticos tratados com insulina ( $D+$ Ins). Não há diferença estatística entre os grupos avaliados ( $n=3 /$ ponto/grupo) para nenhum gene em questão. ANOVA bifatorial seguida de Bonferroni. 
É possível notar pelos perfis acima apresentados que há uma variação discreta ao longo do dia na expressão dos genes em questão. Por outro lado, essa variação é mais acentuada para os genes da Aanat e do adrenoceptor do tipo $\beta$, nos quais observamos aumento na expressão durante a fase escura do ciclo, entre os ZTs 12 e 24. 


\subsection{Expressão proteica da AANAT}

A expressão proteica da enzima passo limitante na via de síntese da melatonina, a AANAT, foi avaliada para os animais controles, diabéticos e diabéticos tratados com insulina ao longo de 5 pontos, sendo estes representantes da transição da fase clara para a escura (ZT 12), escotoperíodo (ZTs 15, 18 e 21) e transição da fase escura para a fase clara (ZT 24). A variação ao longo desses pontos para essa proteína pode ser visualizada na figura 9 a seguir.

Figura 9 - Expressão proteica da AANAT.
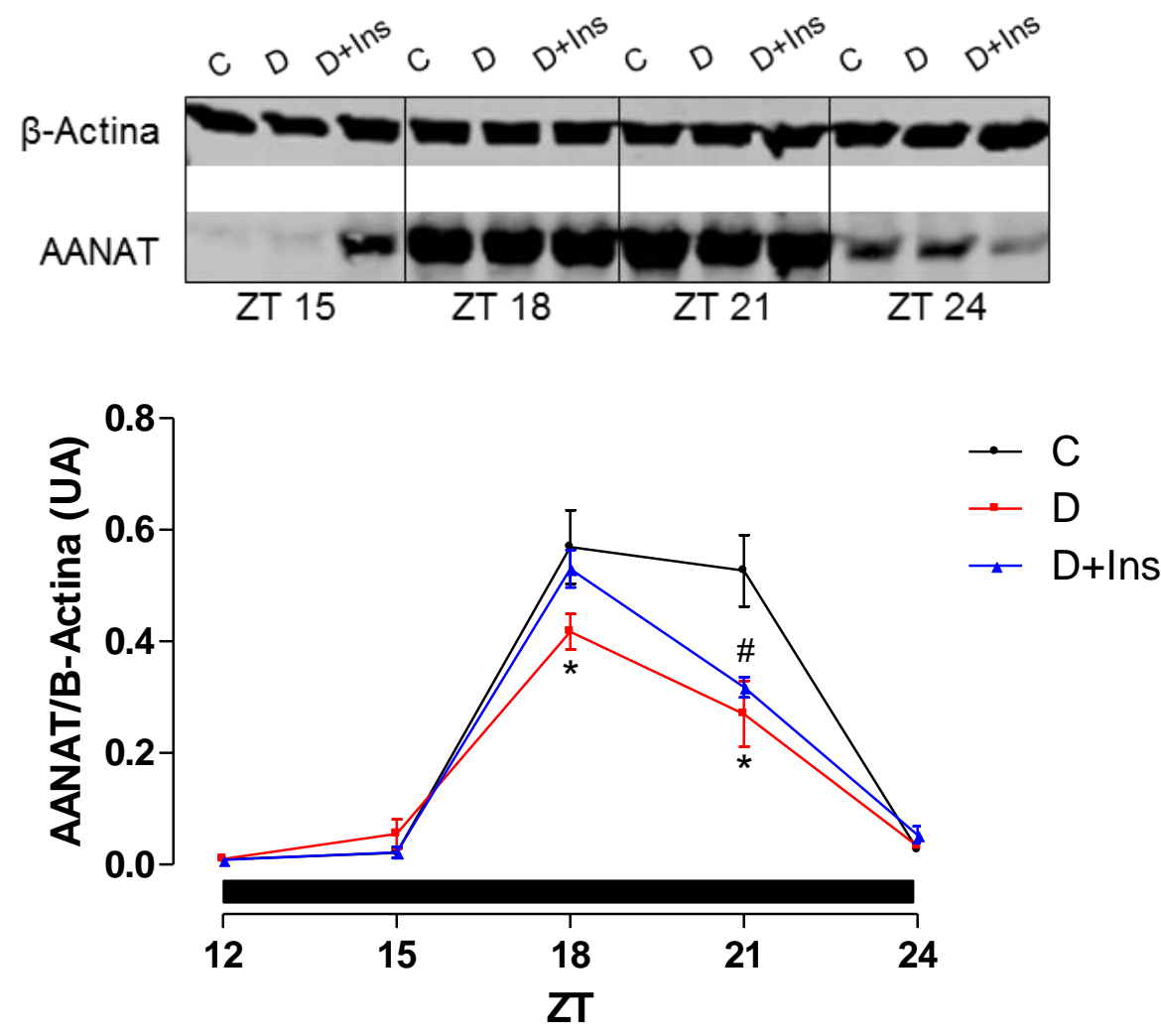

É possível observar uma variação ao longo dos pontos estudados para a proteína da AANAT, com valores próximos ou equivalentes a zero no ZT12 e com valores crescentes ao longo dos ZTs subsequentes, caindo novamente a valores próximos de zero no ZT 24. É possível notar ainda uma menor expressão proteica no grupo diabético sem tratamento (D) em relação ao grupo cujo controle glicêmico foi realizado ao longo do período experimental (D+Ins) e ao grupo controle (C) ( $n=6 /$ grupo/ponto). ANOVA bifatorial seguida de Bonferroni com $p<0,0001$ para o fator $Z T$ e $p=0,0027$ para a interação tratamento $\times Z T$. ${ }^{*} p<0,05$ vs $C$. $\# p<0,05$ vs $C$.

É possível notar que o perfil verificado para a expressão proteica da AANAT segue o mesmo padrão encontrado para a sua expressão gênica ao longo do escotoperíodo, com os valores máximos sendo registrados para os ZTs 18 e 21 de 
acordo com o observado para os animais controles, enquanto os animais diabéticos sem tratamento apresentam um menor conteúdo proteico no período correspondente, sendo significativa a diferença nos pontos em que a proteína da AANAT é justamente mais expressa. Já os animais diabéticos tratados com insulina revelam a normalização parcial do conteúdo proteico em relação aos animais controles no ZT 18, momento de máxima síntese de melatonina na glândula pineal, enquanto que no ZT 21 já há diferença entre o grupo tratado com insulina e o grupo controle. 


\subsection{Atividade da AANAT}

A análise da atividade foi realizada a partir da glândula pineal retirada no momento da eutanásia, a mesma utilizada para a verificação da concentração de melatonina. Os dados obtidos são apresentados na Figura 10 a seguir.

Figura 10 - Atividade da AANAT.

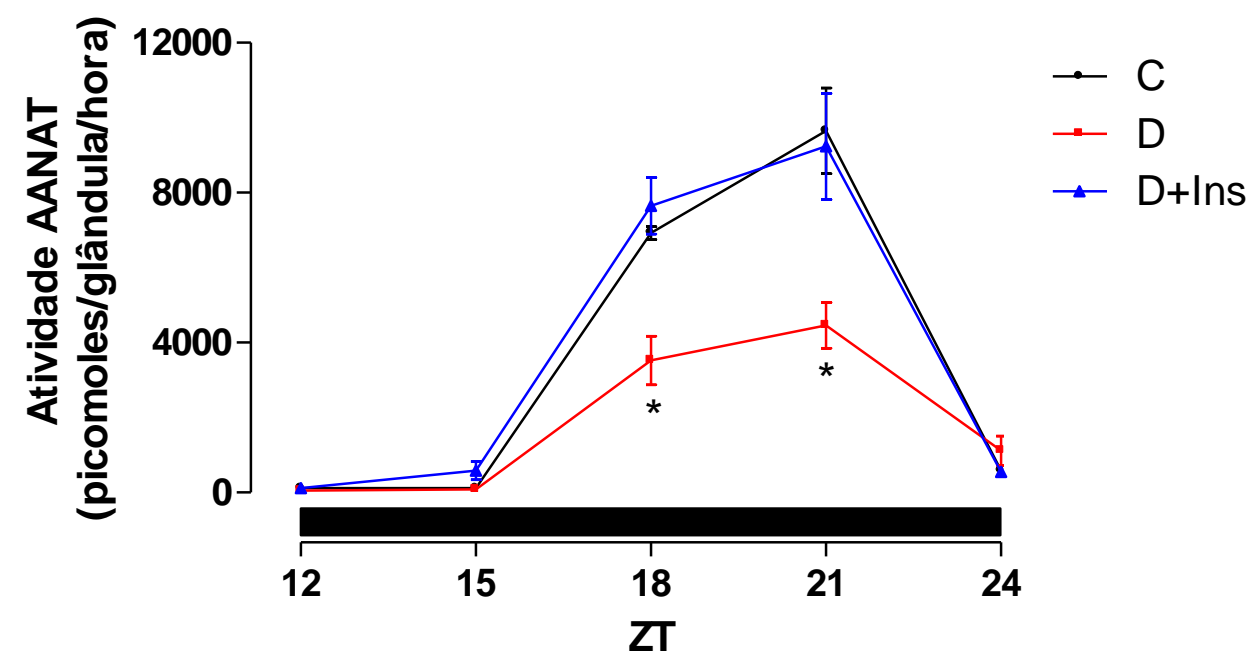

A análise da atividade enzimática foi realizada para os grupos controle $(C, n=23)$, diabético $(D, n=38)$ e diabético tratado com insulina ( $D+$ Ins, $n=39$ ). ANOVA bifatorial seguida de Bonferroni com $p<0,001$ para o fator tratamento; $p<0,0001$ para o fator $Z T$ e $p<0,05$ para a interação tratamento $\times Z T$. ${ }^{*} p<0,05$ vs $C$ e $D+$ Ins.

A análise do gráfico permite verificar a queda da atividade da AANAT no grupo diabético não tratado e a reversão desse aspecto no grupo tratado que não apresentou diferenças estatísticas quanto à atividade enzimática quando comparado com o grupo controle. De tal maneira observa-se que esse gráfico acompanha os resultados encontrados para o gráfico da melatonina, em que se nota a reversão da redução em sua síntese para o grupo diabético tratado com insulina.

Ainda, é possível observar que as expressões gênica e proteica da AANAT são mais acentuadas na fase escura do ciclo, aspecto esse que se reflete diretamente na sua atividade enzimática e, consequentemente, na síntese de melatonina. Essa característica contribui para a caracterização da AANAT como a enzima passo limitante na via de síntese da indolamina pineal. 


\subsection{Conteúdo de AMPc}

Os ratos cujas glândulas foram direcionadas para o estudo do conteúdo de AMPc pineal foram eutanasiados no escotoperíodo. A escolha dessa fase está baseada em estudos que demonstraram a relação entre o aumento desse segundo mensageiro e a ativação da enzima AANAT. A Figura 11 permite a análise dos dados obtidos por ELISA.

Figura 11 - Conteúdo de AMPc na glândula pineal durante o escotoperíodo.

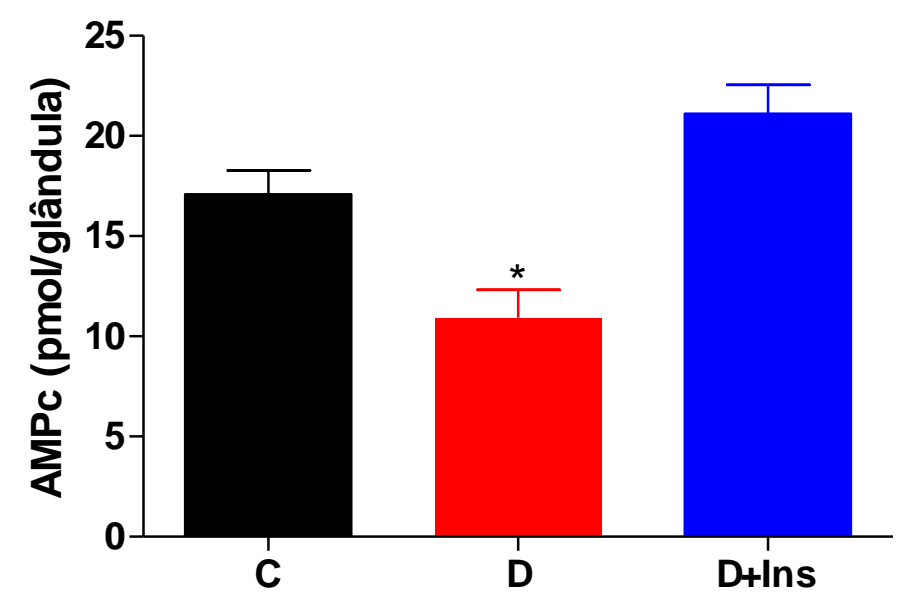

A análise foi realizada para os grupos controle $(C, n=28)$, diabético $(D, n=24)$ e diabético tratado com insulina ( $D+\ln s, n=28)$. ANOVA unifatorial seguida de Bonferroni com ${ }^{*} p<0,05$ vs $C$ e $D+\ln s$.

É possível verificar que o grupo de ratos diabéticos tratados com insulina não apresentou diferença estatística em relação ao grupo controle, o que indica que a normalização da glicemia obtida com o tratamento parece estar relacionada a integridade da sinalização noradrenérgica na glândula pineal representada pelo conteúdo do segundo-mensageiro AMPc equivalente ao encontrado para o grupo de ratos que não sofreu manipulação. 


\subsection{Microdiálise da pineal}

O conteúdo de melatonina obtido diariamente durante o período de 17 dias por microdiálise da glândula pineal de um único rato está registrado na Figura 12 localizada a seguir.

Figura 12 - Produção diária de melatonina avaliada por microdiálise.

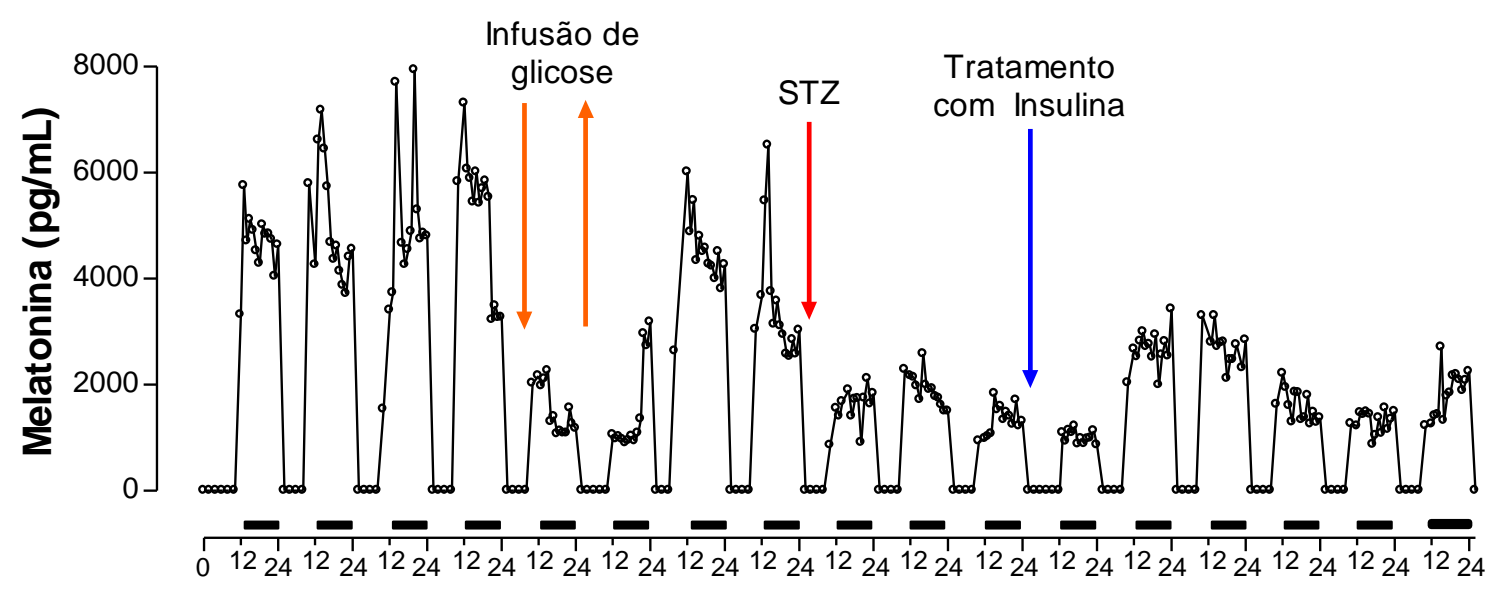

O período de coleta de 17 dias está representado no eixo $\mathrm{x}$, onde as barras pretas indicam $12 \mathrm{~h}$ da fase escura e os espaços em branco indicam $12 \mathrm{~h}$ correspondentes a fase clara. É possível notar que a produção de melatonina $(\mathrm{pg} / \mathrm{mL})$ se dá exclusivamente na fase escura do dia em qualquer condição a qual o rato foi submetido. Dias 1 a 4: controle; Dia 5: injeção intra-pineal de glicose; Dias 6 a 8: controle pós-injeção intrapineal de glicose; Dias 9 a 11: diabético; Dias 12 a 17: diabético tratado com insulina.

A análise dos picos de melatonina representados no gráfico permite notar que os valores verificados para os quatros primeiros dias em que o animal esteve na condição de controle sofreu queda abrupta no quinto dia, momento em que se deu a injeção intra-pineal de glicose a $500 \mathrm{mg} / \mathrm{dL}$, concentração equivalente a glicemia de um rato diabético. No quinto dia, a solução de glicose feita com Ringer foi injetada ao longo de todo o período do escuro, sendo que ao final dessa fase, o sistema de cânulas foi lavado para a retirada completa da solução com glicose do sistema. Nos três dias (6-8) que sucederam a injeção, o animal recebeu apenas Ringer pelo sistema de cânulas. No entanto, é possível verificar que mesmo na ausência da infusão de glicose, os seus efeitos perduraram ao longo do dia 6, em que ainda era possível constatar queda de aproximadamente três vezes na melatonina dialisada quando comparado a produção ao longo dos dias controles, revelando um efeito residual da alta concentração de glicose quanto a síntese de melatonina pineal. Apenas no segundo dia após a parada da perfusão da glândula com solução 
contendo alta concentração de glicose é que a produção do hormônio retornou a níveis equivalentes aos registrados no período controle.

Ao final da oitava noite, o rato foi submetido a uma injeção de STZ de 60 $\mathrm{mg} / \mathrm{Kg}$ para indução do quadro diabético. Assim, um dia após a indução, a aferição da glicemia de $468 \mathrm{mg} / \mathrm{dL}$ confirmou a instalação do quadro diabético. Nota-se que já nesse dia a produção de melatonina caiu para níveis semelhantes aos registrados no dia de infusão intra-pineal de glicose em alta concentração, em que o animal apresentou glicemia de $91 \mathrm{mg} / \mathrm{dL}$, estando dentro dos níveis normoglicêmicos.

A baixa produção de melatonina do período correspondente aos dias 9 a 11 sofre alterações a partir do tratamento com insulina, iniciado no décimo segundo dia de microdiálise. De acordo com o verificado no gráfico, é possível notar que o primeiro dia de tratamento com insulina ainda não apresenta uma normalização da produção de melatonina, aspecto que se assemelha ao que observamos quanto ao perfil da indolamina 1 dia após a infusão intra-pineal de glicose. É somente a partir do segundo dia após o início do tratamento em que constata-se a tendência de normalização na produção da melatonina pineal, com aumento em quase 50\% quando comparado ao período em que o animal encontrava-se diabético e sem tratamento.

O tratamento com insulina foi inicialmente feito seguindo o protocolo adotado para os grupos independentes, com $4 \mathrm{U}$ de insulina no início da noite dos animais e $2 U$ no início do dia. Com a aferição da glicemia no meio da noite após três dias do início do tratamento, foi verificado que essa se encontrava em $25 \mathrm{mg} / \mathrm{dL}$. A partir desse momento, as unidades diárias foram manipuladas em uma tentativa de adequar o tratamento ao perfil do animal. Porém, a continuidade das coletas foi interrompida no décimo sétimo dia em virtude do desacoplamento da sonda da cabeça do rato.

Apesar da impossibilidade de se continuar a microdiálise até o décimo segundo dia, conforme o padrão dos grupos independentes, observa-se uma forte tendência à regularização da síntese de melatonina com a normalização da glicemia obtida com a reposição de insulina. Ainda, é essencial destacar o efeito agudo que o surto hiperglicêmico apresenta na glândula pineal, ocasionando a queda drástica na produção hormonal, efeito este que pode se estender por até um dia após a regularização do aporte glicêmico à estrutura. 


\subsection{Cultura de células pineais isoladas}

As células obtidas por meio da dissociação de glândulas pineais de animais controles, incubadas em meios contendo alta concentrações de glicose $(500 \mathrm{mg} / \mathrm{dL})$, usualmente encontrada em ratos diabéticos ou concentrações fisiológicas de glicose (100 mg/dL), foram submetidos a estimulação por noradrenalina num estudo de dose $x$ efeito como descrito anteriormente. Foi procedida a dosagem de melatonina produzida por tais células, de acordo com o apresentado na Figura 13.

Figura 13 - Produção de melatonina em cultura de células isoladas de pineais mediante estímulo noradrenérgico.

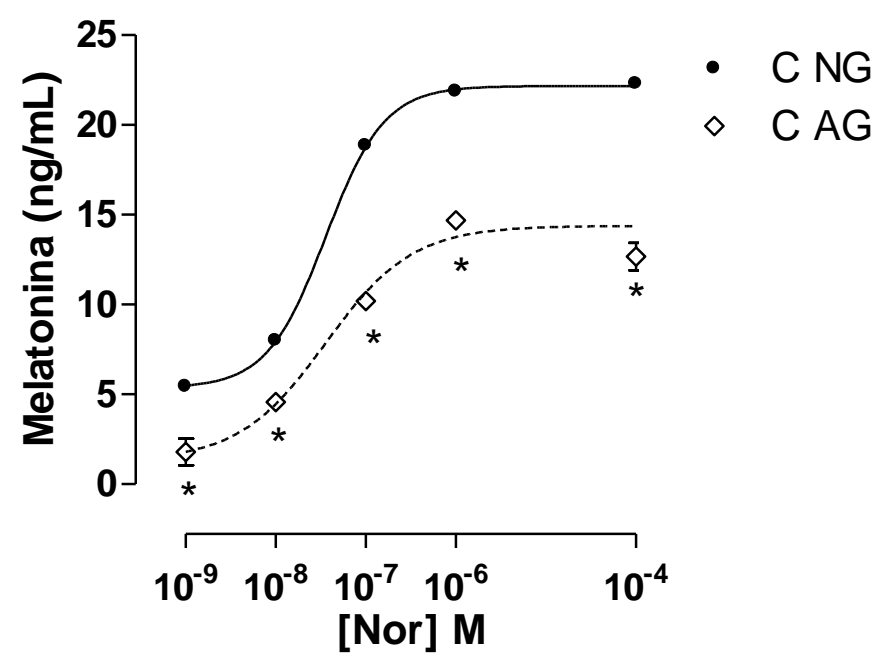

As células foram mantidas em meios com concentração normal ( $N G n=10$ por ponto) e alta de glicose (AG $n=10$ por ponto) submetidos a diferentes concentrações de noradrenalina. ANOVA bifatorial seguida de Bonferroni com $p<0,001$ para o fator tratamento; $p<0,0001$ para o fator concentração $e$ $p<0,001$ para a interação tratamento $x$ concentração. ${ }^{*} p<0,001$ vs $C$ NG.

É essencial destacar que as células foram obtidas de glândulas de animais intactos ( $n=10 /$ grupo) e que apenas o estímulo agudo em cultura com maior concentração de glicose foi suficiente para originar a diferença significativa no conteúdo da indolamina pineal, mostrando um deslocamento da curva de doseresposta para a direita e redução máxima da resposta.

Seguindo o mesmo padrão de cultura citado, células obtidas de glândulas de animais diabéticos sem tratamento e diabéticos tratados com insulina foram incubadas em meios contendo glicose nas concentrações elevada e normal e submetidos ao estímulo com noradrenalina a $10^{-4} \mathrm{M}$, concentração em que se obteve 
a resposta máxima, como observado acima. A dosagem da melatonina produzida por essas células em comparação a células obtidas a partir de animais controle e cultivadas nas mesmas condições experimentais está representada na Figura 14 a seguir.

Figura 14 - Produção de melatonina em cultura de células isoladas de pineais de ratos controles, diabéticos e diabéticos tratados com insulina.

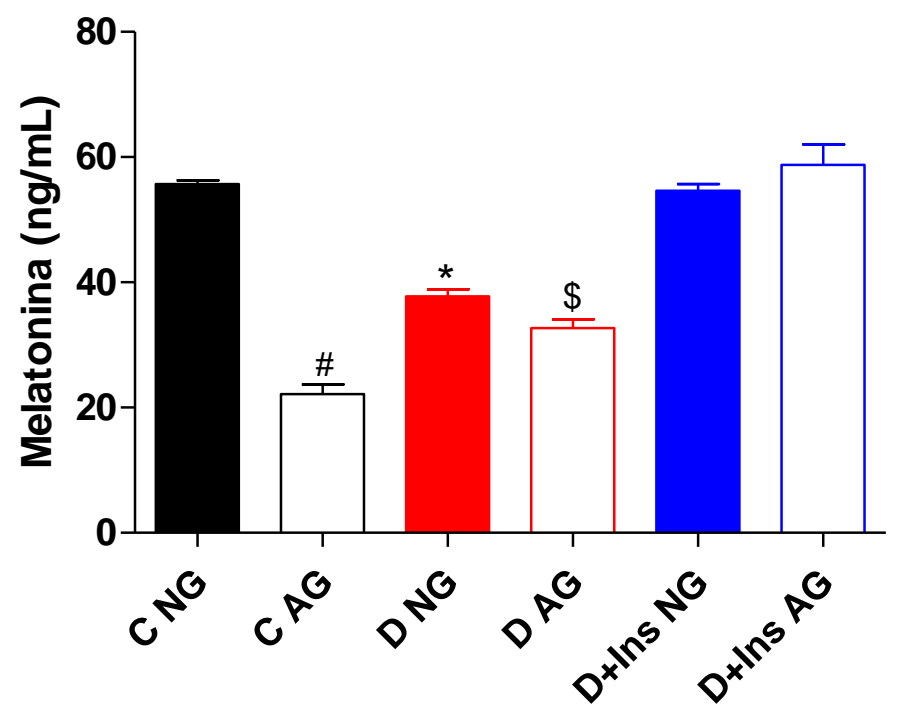

Cultura realizada a partir das glândulas de animais controles (C), diabéticos (D) e diabéticos tratados com melatonina ( $D+$ Ins) mantidos em meios com alta concentração de glicose (AG) e concentração normal de glicose (NG) submetidos ao estímulo com noradrenalina a $10^{-4} \mathrm{M}$ ( $\mathrm{n}=5 / \mathrm{grupo}$ ). ANOVA unifatorial seguida de Bonferroni. \#p $<0.05$ vs todos os grupos; ${ }^{*} p<0.05$ vs todos os grupos exceto por DHG; $\$ p<0.05$ vs todos os grupos exceto por DNG.

Além da queda constatada de melatonina tanto em pinealócitos mantidos em cultura quanto em glândulas de animais diabéticos (Figura 7) é possível constatar o efeito agudo de elevada concentração de glicose $(500 \mathrm{mg} / \mathrm{dL})$ em pineais dissociadas de animais controles, revelando uma produção aproximadamente $30 \%$ menor da indolamina em relação ao seu grupo controle C NG. Ainda, é possível verificar a tendência de normalização da produção de melatonina nas células obtidas a partir de glândulas de animais diabéticos tratados com insulina e mantidos em meio com concentração normal de glicose, indicando o efeito benéfico da manutenção da glicemia a longo prazo para o metabolismo da glândula pineal.

Nota-se, ainda, que as células dissociadas a partir de glândulas de animais controles apresentam um conteúdo médio de melatonina de $55,6 \mathrm{ng} / \mathrm{mL}$ e 22,2 $\mathrm{ng} / \mathrm{mL}$ para os grupos $\mathrm{C} \mathrm{NG} \mathrm{e} \mathrm{C} \mathrm{AG,} \mathrm{respectivamente,} \mathrm{tendo} \mathrm{o} \mathrm{primeiro} \mathrm{grupo} \mathrm{média}$ 
superior àquele dos animais diabéticos D NG $(37,7 \mathrm{ng} / \mathrm{mL})$ e $D$ AG $(32,7 \mathrm{ng} / \mathrm{mL})$, enquanto que células provenientes de glândulas de animais diabéticos tratados com insulina e cultivados em meio com glicose regular revelam uma produção média de melatonina de $54,6 \mathrm{ng} / \mathrm{mL}$, semelhante ao verificado para o grupo C NG. Salienta-se que a manutenção das células dos animais diabéticos em meio com glicose em quantidade regular pelo período de 5 horas indica um efeito residual da hiperglicemia em relação a síntese de melatonina.

Ainda, a produção média de melatonina por células de animais diabéticos tratados com insulina e mantidos em meio com concentração alta de glicose, que foi de aproximadamente $58,7 \mathrm{ng} / \mathrm{mL}$ pode indicar um efeito residual do tratamento com insulina feito 1:30 antes da obtenção das glândulas a partir dos animais. 


\subsection{Atividade da $\mathrm{Na}^{+} / \mathrm{K}^{+}$ATPase pineal}

A atividade da enzima $\mathrm{Na}^{+} / \mathrm{K}^{+}$ATPase foi avaliada em animais controles, diabéticos e diabéticos tratados com insulina. As glândulas pineais foram retiradas no momento da eutanásia, que ocorreu em cinco pontos ao longo do escotoperíodo, quais sejam ZTs 12, 13, 14, 15 e 18. A atividade representada na figura 15 abaixo corresponde a média desses 5 ZTs.

Figura 15 - Atividade da $\mathrm{Na}^{+} / \mathrm{K}^{+}$ATPase pineal.

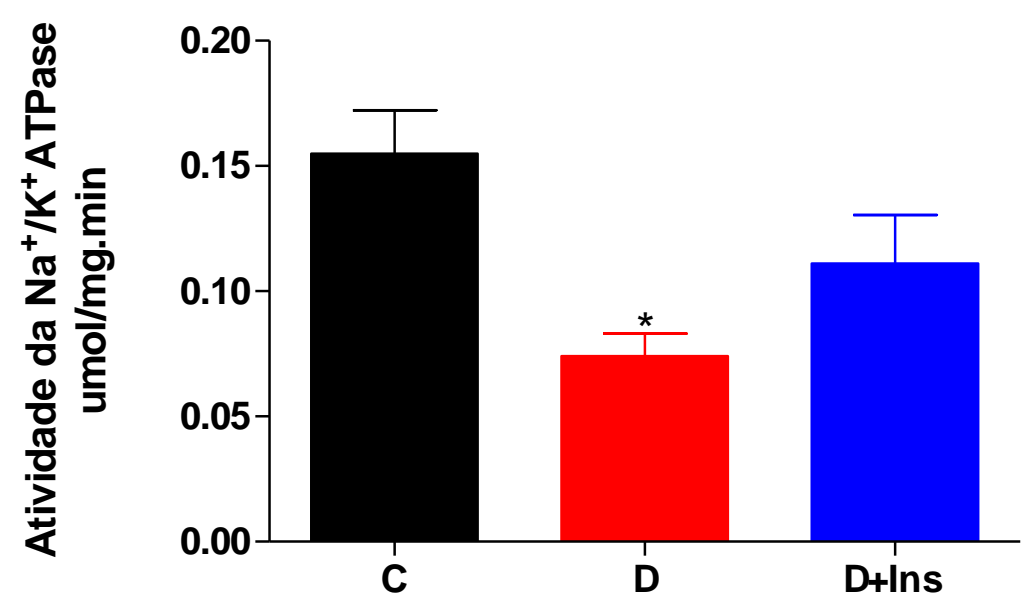

O teste foi realizado para os animais controles $(C, n=31)$, diabéticos $(D, n=35)$ e diabéticos tratados com insulina ( $D+\operatorname{lns}, n=31)$. ANOVA unifatorial seguida de Bonferroni. ${ }^{*} p<0,05$ vs $C$.

A menor atividade da bomba de $\mathrm{Na}^{+} / \mathrm{K}^{+}$apresenta-se como mais um dos parâmetros alterados no grupo diabético em relação ao grupo de animais controles. No primeiro grupo citado, a média da atividade foi de $0,07 \mu \mathrm{mol} / \mathrm{mg} \cdot \mathrm{min}$, enquanto no último o registro foi de $0,16 \mu \mathrm{mol} / \mathrm{mg}$.min. $O$ grupo de ratos diabéticos tratados com insulina apresentou atividade média de $0,11 \mu \mathrm{mol} / \mathrm{mg} . \mathrm{min}$, valor bastante próximo ao verificado para os animais controles, revelando a tendência de normalização na atividade dessa enzima em animais submetidos ao controle glicêmico, por mais que tal diferença não tenha sido caracterizada como estatiscamente significativa. O período reservado para a avaliação do desempenho da $\mathrm{Na}^{+} / \mathrm{K}^{+} A T P a s e$ justifica-se por ser esse o momento crítico de ativação da bomba na glândula pineal, de forma que eventuais acontecimentos que pudessem alterar agudamente a produção hormonal seriam verificados igualmente na janela temporal citada. 


\section{DISCUSSÃO}

A associação entre 0 diabetes, insulina e melatonina apresenta grande relevância na atualidade em função do crescente número de pessoas diagnosticadas com tal doença mundialmente e ainda em virtude dos inúmeros benefícios que a terapia com melatonina pode proporcionar a esses indivíduos.

Estudos que abordam a associação mencionada apontam para a importância da melatonina como molécula antioxidante, auxiliando a reduzir o grau de estresse oxidativo pancreático e também o quadro de hiperglicemia verificado em modelos de animais diabéticos por STZ pré-tratados com melatonina (ABDEL-WAHAB; ABDALLAH, 2000). Outros estudos (GARCIA et al., 2008, 2010) evidenciam a relação entre os dois hormônios, que ocorre pelo estímulo na síntese de melatonina através da insulina, em concentração fisiológica de $10^{-8} \mathrm{M}$, em culturas padrão e sincronizada de glândulas pineais, evento este atribuído ao aumento na atividade da AANAT ocasionada por ação direta ou indireta da fosfatidilinositol-3-quinase (PI3K), importante proteína da via de sinalização insulínica. Lima et al. (2001) também tratam de tal associação, demonstrando a ocorrência de hiperglicemia e hipoinsulinemia associadas a alterações morfológicas em células $\beta$ - pancreáticas de ratos pinealectomizados, aspecto igualmente avaliado em pacientes diabéticos em que foi constatada a degeneração de células pancreáticas e redução plasmática da indolamina pineal (PESCKE, 2006). Contribuindo para a solidificação da relação entre melatonina e insulina, Anhê et al. (2004) trazem um dos pontos de convergência da ação de tais hormônios, que é a ativação da subunidade $\beta$ do receptor insulínico (IR) e a fosforilação do seu substrato IRS-1 pela melatonina no hipotálamo e em tecidos periféricos.

Assim, com base nas informações fornecidas por tais investigações, o presente trabalho questionou se o tratamento com insulina de ratos diabéticos tipo I reverteria a queda na síntese de melatonina verificada em animais diabéticos, quadro que poderia estar associado a diversas complicações dessa patologia. Objetivando um maior esclarecimento de tal evento foram também explorados passos da via de síntese da melatonina que se mostraram alterados em animais diabéticos sem tratamento (AMARAL, 2009).

Dados obtidos no nosso grupo de estudo (AMARAL, 2009) e do presente trabalho corroboram as informações da literatura (CHAMPNEY et al., 1983; 
PESCHKE et al., 2006; STEBELOVÁ et al., 2007), demonstrando uma diminuição na síntese de melatonina mediante o quadro de diabetes induzido por STZ. Apenas certos estudos de um único grupo contrastam com as demais citações, por terem verificado uma elevação na concentração de melatonina plasmática em ratos diabéticos tipo I por STZ intraperitoneal na concentração de $60 \mathrm{mg} / \mathrm{kg}$ (PESCHKE et al., 2008), levantando a hipótese de uma compensação desempenhada pela glândula pineal para contrabalancear os distúrbios metabólicos do quadro diabético. Ainda, o incremento da indolamina em questão foi atribuído ao aumento dos receptores $\beta$-adrenérgicos, das expressões gênica da AANAT e da HIOMT, assim como de adrenalina e noradrenalina (PESCKE et al., 2008, 2012), o que não foi evidenciado pelo nosso grupo (AMARAL, 2009).

A redução do ganho de peso verificada no grupo diabético sem tratamento quando em comparação aos grupos controle e diabético tratado com insulina era esperada. A mesma relação foi encontrada em um estudo com ratos Wistar controle e diabéticos por STZ a $65 \mathrm{mg} / \mathrm{kg}$, mantidos nessa condição pelo período de 17 dias (STEBELOVÁ et al., 2007). Peschke et al. (2008) também observaram redução do ganho de peso dos animais diabéticos (ratos Wistar) após 6 semanas da indução do quadro por STZ intraperitonial a $60 \mathrm{mg} / \mathrm{Kg}$ Montilla et al. (1998) e Vural et al. (2001) verificaram da mesma maneira a queda de peso em ratas Wistar tratadas com STZ a $60 \mathrm{mg} / \mathrm{kg}$, mantidas diabéticas por 6 semanas e por 8 semanas, respectivamente. Assim, os dados da perda de peso juntamente com a hiperglicemia detectada por testes com o sangue obtido a partir da veia caudal dos animais foram os principais fatores que comprovaram a instalação do quadro diabético ao longo do experimento. Abdel-Wahab e Abd-Allah (2000) encontraram hiperglicemia após 3 dias da indução da condição com STZ na concentração de $60 \mathrm{mg} / \mathrm{Kg}$ em camundongos albinos suíços, sendo o mesmo verificado para ratos no experimento de Vural et al. (2001). A queda de peso ou o menor ganho de massa estão associados ao prejuízo na captação de glicose pelas células, em virtude da insulina muito reduzida ou ausente e ainda em função da mobilização das reservas do tecido adiposo, uma vez que a gordura é considerada a segunda fonte de recursos energéticos, quando o uso de carboidratos está inviabilizado. Há, portanto, ativação da lipólise (HALL, 2011).

O quadro de glicemia elevada foi contornado com a administração de insulina duas vezes ao dia. No começo da fase de escuro do ciclo, o que equivale ao momento de maior atividade dos roedores e, portanto, ao período em que os 
animais se alimentam, uma combinação de 2 unidades de insulina de ação prolongada (Glargina/Lantus $\AA$, Sanofi Aventis) e de 2 unidades de insulina regular (Humulin®, Lily, EUA) era administrada. Foi possível notar que a média glicêmica dos animais diabéticos tratados com insulina foi mantida inferior àquela dos animais diabéticos sem tratamento ao longo de todo o escotoperíodo (ZTs 12 a 24). No início da fase de claro, 2 unidades de insulina de ação prolongada (Glargina/Lantus®,Sanofi Aventis, Alemanha) eram injetadas de forma subcutânea.

Complementando os dados verificados para os grupos independentes, a microdiálise realizada com um rato submetido a diferentes condições traz algumas informações adicionais e de grande importância sobre a dinâmica da síntese de melatonina em um modelo animal primeiramente controle e posteriormente insulinodependente. Antes de mais nada, é possível destacar que são pequenas as variações intrínsecas ao indivíduo quanto a produção diária da indolamina pineal na condição original de controle, estabilidade essa que se mantém por um longo período de experimentação, reforçando a validade dos dados obtidos (BARASSIN et al., 1999). Além desse aspecto, um ponto fundamental associado ao quadro diabético e a produção de melatonina foi esclarecido: a injeção intra-pineal de uma solução com elevada concentração de glicose, através da técnica de microdiálise reversa, no momento em que o organismo do animal apresentava-se normoglicêmico e com normoinsulinêmico promoveu queda na síntese de melatonina da mesma forma como foi constatado mais tarde mediante a injeção com a droga indutora do quadro diabético. Assim, com a vantagem própria à microdiálise, que permite a verificação simultânea da síntese de melatonina mediante estimulação com determinada substância (BARASSIN et al., 2000), torna-se possível aventar que a hiperglicemia é um fator de grande relevância para a ocorrência das alterações glandulares e de síntese de melatonina observadas em organismos diabéticos. Ainda, o reestabelecimento dos parâmetros avaliados no presente trabalho deve-se ao controle glicêmico pelo tratamento com insulina, diferentemente do que foi abordado recentemente em um trabalho de Peschke et al. (2012). O hormônio pancreático parece atuar como um modulador da síntese de melatonina em condições fisiológicas normais, conforme constatado pelos trabalhos de Garcia et al. (2008; 2010), sendo também essencial, como mostrado aqui, para o reestabelecimento adequado da síntese de melatonina pineal em organismos diabéticos em função do controle glicêmico. 
A cultura de células dissociadas a partir de glândulas pineais de animais controles, diabéticos e diabéticos tratados com insulina reforça os resultados indicados pela infusão intra-pineal de glicose durante a microdiálise. Nesse caso, constata-se além da queda já esperada no conteúdo de melatonina produzida pelas células oriundas de glândulas de organismos diabéticos mantidos em meio com alta concentração de glicose, uma redução de aproximadamente $60 \%$ nas células obtidas de glândulas de animais controles incubados nas mesmas condições. Tal achado indica um componente agudo das modificações na síntese da indolamina induzidas pelo quadro hiperglicêmico. Por outro lado, a baixa produção de melatonina a partir de células de animais diabéticos mantidos nessa condição por 15 dias e então incubadas por 5 horas em meio contendo concentração regular de glicose associada a produção regular de melatonina pelas células de animais diabéticos tratados com insulina, incubadas nas duas condições, indicam também um componente residual da hiperglicemia.

Nesse contexto, é válido especular que a relação entre insulina, melatonina e metabolismo energético possui também um caráter crônico, no sentido de que os efeitos de um hormônio sobre o outro e em relação ao processamento de substratos se manifesta não pela presença de um modulador apenas, mas ainda pela atuação de ambos a longo prazo, conforme observado por Zanquetta et al. (2003) em determinada condição experimental, em que se verificou que a falta crônica de melatonina induz a modificações quanto a homeostase da glicose.

Considerando a relação temporal dual citada acima, as alterações verificadas pela infusão intrapineal de glicose resultam de mecanismos cuja regulação é, provavelmente, aguda. Nesse caso é levantada a possibilidade de tal prejuízo na síntese de melatonina pineal poder ser atribuída ao desajuste no funcionamento da $\mathrm{Na}^{+} / \mathrm{K}^{+}$ATPase glandular. O bloqueio desse canal pela ouabaína parece exercer um papel considerável na regulação da síntese da indolamina, conforme verificado em cultura de pinealócitos (SUGDEN et al., 1986). Outras investigações a respeito da $\mathrm{Na}^{+} / \mathrm{K}^{+}$ATPase revelaram que o bloqueio dessa enzima pela ouabaína inviabilizou o estímulo noradrenérgico da atividade da AANAT em glândulas pineais de ratos adultos (CEÑA et al., 1987). Semelhante informação aliada a constatada queda na atividade da $\mathrm{Na}^{+} / \mathrm{K}^{+}$ATPase e da AANAT em ratos diabéticos no presente trabalho fala a favor desse mecanismo como uma possível alteração responsável pela redução na síntese de melatonina nesses organismos. Ainda, é válido ressaltar que 
a tendência à normalização da atividade da $\mathrm{Na}^{+} / \mathrm{K}^{+}$ATPase em ratos diabéticos tratados com insulina juntamente com a atividade reestabelecida da AANAT nos mesmos indica que a normalização glicêmica parece desempenhar um papel regularizador desses mecanismos, contribuindo para a produção adequada da indolamina pineal em animais que receberam a reposição com insulina.

Em outros territórios, como no músculo cardíaco de ratos diabéticos por STZ, foi igualmente constatada a queda na atividade da $\mathrm{Na}^{+} / \mathrm{K}^{+}$ATPase (VER et al., 1997). Ainda, um estudo recente com camundongos diabéticos não-obesos (do inglês non-obese diabetic mouse ou NOD mouse) observou uma redução concomitante na atividade da $\mathrm{Na}^{+} / \mathrm{K}^{+}$ATPase no coração, rim e pâncreas associada a hiperglicemia quando comparado ao camundongos controles (SHI et al., 2012). Tal trabalho sugere a queda na atividade da bomba de sódio como uma alteração sistêmica do DM tipo I justificada por uma sensibilidade alterada da enzima pelo íon sódio e que pode ser um dos agravantes do quadro diabético nesses animais.

Nesse contexto torna-se plausível sugerir que tal mecanismo esteja se manifestando ao longo de todo o período de desbalanço glicêmico avaliado nos grupos independentes, uma vez que a normalização da glicemia pelo tratamento com injeções de insulina foi suficiente para o reestabelecimento da produção de melatonina. Esse ponto é corroborado pelo trabalho de Barone (2012) em que seres humanos portadores de DM tipo I apresentaram melhora generalizada dos ritmos biológicos a partir do momento em que adequaram o tratamento do quadro diabético em relação a pacientes diabéticos com descontrole glicêmico.

Portanto, mediante a comprovada queda na síntese de melatonina em organismos diabéticos tipo I e sua reversão com a reposição de insulina e consequente normalização glicêmica, alguns mecanismos que podem contribuir para justificar a normalização da síntese de melatonina em ratos diabéticos tratados foram evidenciados. Dentre os processos que merecem destaque temos a queda no conteúdo proteico e na atividade da AANAT em ratos diabéticos sem tratamento. Essa é a enzima chave para a produção de melatonina, devido a sua atuação convertendo serotonina a $\mathrm{N}$-acetilserotonina, precursora da melatonina, durante a fase escura do ciclo. Tal afirmação é corroborada pelos resultados encontrados no presente trabalho (KLEIN et al., 1970; KLEIN e WELLER, 1970, 1972; PARFITT et al., 1976; YU et al., 1993). 
Ainda, através da sobreposição das informações da concentração de melatonina e da proteína e atividade enzimática da AANAT do presente estudo verificamos a relação entre a normalização destas, mesmo que parcial no caso da proteína, e a reversão na queda da síntese de melatonina no grupo diabético que recebeu tratamento com reposição de insulina, aproximando este grupo do controle no quesito em discussão. É válido destacar nesse contexto que o perfil proteico da AANAT, que acompanha o mesmo do grupo controle até o ZT 18, apresenta diferença apenas no ZT 21 em função, provavelmente, do controle glicêmico não ser completamente eficaz ao longo de todo o escotoperíodo.

É importante destacar que não foram evidenciadas diferenças quanto à expressão gênica na glândula pineal associada aos adrenoceptores $\alpha$ e $\beta$ e ainda em relação às três principais enzimas da via bioquímica de síntese da melatonina pineal, Tph1, Aanat e Hiomt, para os três grupos estudados, indicando que a hiperglicemia não parece desencadear alterações transcricionais na glândula. No entanto, ressalta-se o perfil transcricional que pode ser observado para alguns dos genes em questão e que corroboram dados previamente encontrados na literatura, como é o caso da Aanat, cujo aumento na expressão gênica dependente da estimulação noradrenérgica na fase escura do ciclo de iluminação é consideravelmente pronunciado, chegando a até 150 vezes os valores encontrados para a fase clara (ROSEBOOM et al., 1996). O adrenoceptor $\beta$ também apresenta uma flutuação diária em sua expressão gênica, com valores mais elevados durante o escotoperíodo. Esse aspecto pode estar associado ao aumento da densidade desses receptores em pinealócitos durante a fase escura do ciclo, fator relacionado a maior atividade da via neural que se projeta para a pineal determinando 0 momento de síntese da indolamina em questão (CIPOLLA-NETO; AFECHE, 2008).

Em adição aos parâmetros discutidos, o reestabelecimento no conteúdo pineal do segundo-mensageiro que contribui majoritariamente para a síntese da indolamina na glândula, o AMPc (KLEIN et al., 1970 e 1978), constitui mais um passo na elucidação dos mecanismos originalmente afetados pelo quadro diabético e que se encontram normalizados mediante o tratamento com insulina. É fundamental destacar que o AMPc desempenha função central na indução da atividade da AANAT através da ativação da enzima PKA, que por sua vez está associada à formação do complexo de estabilização e proteção da AANAT, sendo também responsável por sua fosforilação, contribuindo para sua atividade regular e, 
assim, influenciando diretamente a síntese de melatonina pela glândula pineal (KLEIN et al., 1970; KLEIN; WELLER, 1970).

Não obstante, é fundamental que se avalie a atuação sistêmica da melatonina para o maior entendimento das alterações observadas em indivíduos diabéticos. A melatonina age de forma preponderante em órgãos como os rins, baço, duodeno e pâncreas, conforme afirmam Stebelová et al. (2007). A nefropatia, decorrente do predomínio de radicais livres em relação aos compostos antioxidantes, desencadeando o estresse oxidativo, o comprometimento da atuação do sistema imune e a perda de proteção contra oxidação e também da marcação sincrônica gerada pela melatonina e dos genes do relógio no pâncreas são apenas alguns exemplos do comprometimento de funções de um organismo diabético e que podem ter como um dos fatores desencadeadores a queda de melatonina pineal. Nesse contexto, alguns trabalhos abordam esses fatores como consequências para o não-tratamento do diabetes tipo I pela reposição de insulina (VURAL et al., 2001).

Outras condições próprias do estado diabético como processos neurodegenerativos, prejuízos renais, vasculares, hepáticos e até cognitivos são exemplos adicionais de complicações que poderiam ser amenizadas pela administração de melatonina (DANEMAN, 2006; PESCKE et al., 2008).

Com base nos dados levantados pelo presente trabalho em associação com os demais estudos disponíveis na literatura a respeito da síntese de melatonina em organismos diabéticos e ainda em relação aos benefícios experimentados por indivíduos acometidos por essa patologia e que se utilizam da reposição de melatonina como coadjuvante do tratamento da condição diabética (Sudnikovich et al., 2007; Kormaz et al., 2012), é possível afirmar que o interesse pelo assunto cresce consideravelmente nos últimos tempos.

Bonnefont-Rousselot e Collin, 2010 retratam a melatonina como um potente antioxidante, destacando possíveis aplicações dessa no tratamento de doenças e na melhoria de parâmetros associados ao envelhecimento em humanos. Tais autores apontam para um diferencial da indolamina em questão em relação aos demais antioxidantes para o tratamento de condições metabólicas, sendo que a primeira, em virtude de sua característica anfifílica, pode atuar tanto em meios lipofílicos quanto hidrofílicos, contribuindo diretamente para reduzir o estresse oxidativo e ainda regulando a atividade de outras enzimas redutoras. Ainda, o estudo em questão ressalta a não-existência de uma concentração considerada tóxica de melatonina 
em pesquisas realizadas até o presente momento e também revela os inúmeros benefícios associados a sua ingestão por pacientes com diversas condições patológicas. Em outro trabalho do mesmo ano, Rios et al. (2010) reportam variadas funções da melatonina na melhoria de doenças, sendo essa utilizada como uma nova tendência farmacológica, sem descartar a necessidade de mais estudos a respeito da utilização da substância e da importância da orientação médica para tanto. 


\section{CONSIDERAÇÕES FINAIS}

A síntese de melatonina tem mostrado elevada plasticidade, sendo influenciada por agentes específicos que já se encontram descritos na literatura e ainda por determinadas condições, que compilam uma série de fatores que atuam como reguladores positivos ou negativos de sua produção. Dentre essas condições, o quadro diabético destaca-se por sua associação direta com a indolamina em questão.

Vários estudos com resultados discrepantes sobre o presente assunto têm sido publicados ao longo dos últimos anos, sendo a queda na síntese de melatonina pineal e os desdobramentos desse evento no que tange à gênese do quadro diabético quanto ao seu agravamento achados considerados consistentes.

A evolução do diabetes mellitus tipo II para o tipo I à luz da atuação da melatonina ilustra os aspectos apontados anteriormente: a hiperglicemia, fator comum às duas manifestações do quadro, está associada a queda na síntese de hormônio pela glândula pineal. Por sua vez, a redução da indolamina circulante reconhecidamente contribui para a redução da sensibilidade central e periférica à insulina, favorecendo o aumento na produção do hormônio pancreático sem a adequada repercussão de sua atuação, podendo levar a falência das células $\beta$. Ao mesmo tempo, desestrutura-se o sistema de marcação circadiana inerente ao indivíduo pela queda de melatonina e é registrada perda significativa da defesa antioxidante do organismo, questão essa já prejudicada pela auto-oxidação da glicose própria do estado diabético, contribuindo para o agravamento da condição patológica. Nesse ponto é essencial destacar a não-linearidade da ocorrência do fenômeno descrito, sendo de grande dificuldade a ordenação dos processos envolvendo o quadro diabético e a glândula pineal.

Com isso, aponta-se como fator de grande importância a incorporação do conhecimento sobre glândula pineal e melatonina nos estudos sobre o diabetes mellitus. O controle da glicemia merece especial atenção nesse quesito, não apenas para indivíduos em que o quadro de desequilíbrio glicêmico já se instalou, mas também na rotina de indivíduos saudáveis, mas que possuem hábitos desregrados de alimentação, com elevada ingestão calórica próxima ao momento do repouso, o 
que interfere prejudicialmente na síntese de melatonina ou ainda para trabalhadores em turnos invertidos.

Somada à difusão dos estudos sobre a glândula pineal na pesquisa básica é necessária sua extensão à pesquisa clínica, de forma a orientar a sociedade médica a respeito da relevância de se investigar esse hormônio na prática, como se faz comumente com os demais hormônios, contribuindo para a qualidade de vida da população em geral. Ainda nesse contexto é fundamental destacar as peculiaridades pertinentes à administração de melatonina, em virtude desse hormônio apresentarse não apenas como um simples antioxidante, mas também como um importante sincronizador de diversos fenômenos fisiológicos, de forma que a sua utilização ocorra de forma consciente e controlada. 


\section{CONCLUSÕES}

O presente trabalho contribui para o esclarecimento a respeito do que ocorre com a síntese de melatonina em modelos animais de ratos diabéticos tipo I tratados com insulina.

Foi possível constatar que a redução de melatonina pineal nesses organismos está associada à queda do conteúdo proteico e da atividade da enzima passo limitante da via de síntese da indolamina pineal, a AANAT. A esses aspectos somase a queda no conteúdo do segundo mensageiro de maior importância para a síntese de melatonina, o AMPc, nos animais diabéticos. O tratamento com insulina, duas vezes ao dia, foi capaz de regularizar os parâmetros citados, cabendo destacar que a proteína da AANAT apresenta uma reversão apenas parcial em seu conteúdo.

Ainda, foi possível constatar que a alteração no organismo diabético tipo I de maior relevância para o prejuízo que se observa na síntese de melatonina é a hiperglicemia, sendo que a reposição com insulina parece levar a normalização da produção hormonal pela glândula pineal através do controle glicêmico. Um dos possíveis mecanismos envolvidos nesse processo é o funcionamento da $\mathrm{Na}^{+} / \mathrm{K}^{+}$ATPase na glândula pineal, prejudicado em animais diabéticos e com tendência ao reestabelecimento em diabéticos tratados. A hiperglicemia parece não interferir com a expressão gênica na glândula pineal.

Com isso, destaca-se mais uma vez a importância do controle glicêmico em organismos diabéticos, com benefícios que se estendem ao funcionamento adequado da glândula pineal $\mathrm{e}$, consequentemente, à produção regular de melatonina, que por sua vez se reflete na coordenação de variados processos fisiológicos, contribuindo para a homeostase orgânica e bem estar do indivíduo.

No entanto, é de conhecimento geral que semelhante controle não é alcançado apenas pela reposição hormonal, estando os indivíduos acometidos pelo quadro diabético sujeitos às flutuações glicêmicas ao longo do dia nem sempre passíveis de serem contornadas com total eficácia pela utilização de insulina. Nesse contexto, aventa-se o uso, mediante orientação médica adequada, da melatonina como possível coadjuvante no tratamento da condição diabética, podendo também servir como forma de prevenção aos indivíduos que possuem predisposição ao desenvolvimento do diabetes. 


\section{REFERÊNCIAS*}

ABDEL-WAHAB, M. H.; ABD-ALLAH, A. R. A. Possible protective effect of melatonin and/or desferrioxamine against streptozotocin-induced hyperglycaemia in mice. Pharmacol. Res., v. 41, n. 5 , p. 533-537, 2000.

AGIL, A.; ROSADO, I.; RUIZ, R.; FIGUEROA, A.; ZEN, N.; FERNÁNDEZ-VÁZQUEZ, G. Melatonin improves glucose homeostasis in Young Zucker diabetic fatty rats. J. Pineal. Res., v. 52, p. 203-210, 2012.

AMARAL, F. G. Perfil diário e os mecanismos de produção de melatonina pela glândula pineal de ratos diabéticos por estreptozotocina. 2009. $181 \mathrm{f}$. Tese (Doutorado em Fisiologia Humana) - Instituto de Ciências Biomédicas, Universidade de São Paulo, São Paulo, 2009.

ANHÊ, G. F.; CAPERUTO, L. C.; PEREIRA-DA-SILVA, M.; SOUZA, L.C.; HIRATA, A. E.; VELLOSO, L. A.; CIPOLLA-NETO, J.; CARVALHO, C. R. In vivo activation of insulin receptor tyrosine kinase by melatonin in the rat hypothalamus. J. Neurochem., v. 90, n. 3, p. 559-566, 2004.

AMERICAN DIABETES ASSOCIATION. Diabetes basics. Disponível em: <http://www.diabetes.org/diabetes-basics/?loc=GlobalNavDB>. Acesso em: 25 jun. 2012.

ARENDT, J. Melatonin and the mammalian pineal gland. London: Chapman \& Hill, 1995.

BARASSIN, S.; SABOUREAU, M.; KALSBEEK, A.; BOTHOREL, B.; VIVEN-ROELS, B.; MALAN, A.; BUJIS, R. M.; GUARDIOLA-LEMAITRE, B.; PÉVET, P. Interindividual differences in the pattern of melatonin secretion of the Wistar rat. J. Pienal Res., v. 27, p. 193-201, 1999.

BARASSIN, S.; KALSBEEK, A.; SABOUREAU, B.; VIVEN-ROELS, B.; MALAN, A.; BUJIS, R. M.; PEVET, P. Potenttiation effect of vasopressin on melatonin secretion as determined by trans-pineal microdialysis in the rat. J. Neuroendocriol., v. 12, p. 61-68, 2000.

BARRETT, P.; MacLEAN, A.; DAVIDSON, G.; MORGAN, P. J. Regulation of the Mel 1a melatonin receptor mRNA and protein levels in the ovine pars tuberalis: Evidence for a cyclic adenosine 3',5'-monophosphate-independent Mel 1a receptor coupling and an autoregulatory mechanism expression. Mol. Endocrinol., v. 10, p. 892-902, 1996.

BARONE, M. T. U. Ciclo vigília/sono em portadores de diabetes mellitus tipo I. 2011. $26 \mathrm{f}$. Tese (Doutorado em Ciências - Fisiologia) - Instituto de Ciências Biomédicas, Universidade de São Paulo, São Paulo, 2011.

BRAGA, J. R.; AVEZUM, A.; FERREIRA, S. R. G.; FORTI, A. Management of diabetes mellitus and associated cardiovascular risk factors in Brazil - the Brazilian study on the practice of diabetes care. Diabetol. Metab. Syndr., v. 5, p. 1-15, 2013.

BONNEFONT-ROUSSELOT, D.; COLLIN, F. Melatonin: action as antioxidant and potencial applications in human disease and aging. Toxicology, v. 278, p. 55-67, 2010.

\footnotetext{
* De acordo com:

ASSOCIAÇÃO BRASILEIRA DE NORMAS TÉCNICAS. NBR 6023: informação e documentação: referências: elaboração. Rio de Janeiro, 2002.
} 
CALDAS, J. G.; DOMINIQUE, D.; LEDERMAN, H.; CARLIER, R. Estudo por ressonância magnética da região da pineal: pineal normal e cistos simples. Arq. Neuro-Psiquiatr., v. 56, n. 2, p. 237-244, 1998.

CANO, P.; JIMENÉS-ORTEGA, V.; LARRAD, A.; TOSO, C. F. R.; CARDINALI, D. P.; ESQUIFINO, A. I. Effect of a high-fat diet on 24-h pattern of circulating levels of prolactin, luteinizing hormone, testosterone, corticosterone, thyroid-stimulating hormone and glucose, and pineal melatonin content, in rats. Endocrinology, v. 33, p. 118-125, 2008.

CARDINALI, D. P.; VACAS, M. I. Cellular and molecular mechanisms controlling melatonin release by mammalian pineal glands. Cell Mol. Neurobiol., v. 7, p. 323-337, 1987.

CEÑA, V.; GONZÁLEZ-GARCIA, C.; SVOBODA, P.; WELLER, J. L.; KLEIN, D. C. Developmental study of ouabain inhibition of adrenergic induction of rat pineal serotonin $\mathrm{N}$ acetyltransferase (EC 2.3.1.87). J. Biol. Chem., v. 30, p. 14476-14471, 1987.

CHAMPNEY, T. H.; BRAINARD, G. C.; RICHARDSON, B. A.; REITER, R. J. Experimentallyinduced diabetes reduces nocturnal pineal melatonin content in the Syrian hamster. Comp. Biochem. Physiol., v. 76, p. 199-201, 1983.

CHAMPNEY, T. H.; HOLTORF, A. P.; CRAFT, C. M.; REITER, R. J. Hormonal modulation of pineal melatonin synthesis in rats and Syrian hamsters: effects of streptozotocin-induced diabetes and insulin injections. Comp. Biochem. Physiol., v. 83, p. 391-395, 1986.

CIPOLLA-NETO, J.; RECINE, E. G.; MENNA-BARRETO, L. S.; MARQUES, N.; AFECHE, S.G.; SCHOTT, C.; FORTUNATO, G.; SOTHERN, R. B.; HALBERG, F. Perinatal malnutrion, suprachiasmatic nuclear lesioning and circadian-ultradian aspects of spontaneous behaviour of albino rats. Prog. Clin. Biol. Res. v.227, p. 473-489, 1987.

CIPOLLA-NETO, J.; SKORUPA, A.L.; RIBEIRO-BARBOSA, E. R.; BARTOL, I.; MOTA, S. R.; AFECHE, S. C.; DELAGRANGE, P.; GUARDIOLA-LEMAITRE, B.; CANTERAS, N. S. The role of the retrochiasmatic area in the control of pineal metabolism. Neuroendocrinology, $v$. 69, n. 2, p. 97-104, 1999.

CIPOLLA-NETO, J.; AFECHE, S. C. Glândula pineal. In: AIRES, M. M. Fisiologia. Rio de Janeiro: Guanabara Koogan, 2008. p. 980-990.

COLLIN, J. P. Differentiation and regression of the cells of the sensory line in the epiphysis cerebri. In: WOLSTENHOLME, G. E. W.; KNIGHT, J. The pineal gland. London: J. A. Churchill, 1971. p. 79-125.

CORBALÁN-TUTAU, D.; MADRID, J. A.; NICOLÁS, F.; GARAULET, M. Daily profile in two circadian markers "melatonin and cortisol" and associations with metabolic syndrome components. Physiol. Behav., 2012. In press.

DANEMAN, D. Type 1 diabetes. Lancet, v. 367, p. 847-858, 2006.

DUBOCOVICH, M. L. Melatonin receptors: Are there multiple subtypes? TiPS, v. 16, p. 5056. 1995.

DUBOCOVICH, M. L.; MARKOWSKA, M. Functional MT1 and MT2 Melatonin Receptors in Mammals. Endocrine, v. 27, n. 2, p. 101-110, 2005. 
EKSTRÖM, P.; MEISSL, H. Evolution of photosensory pineal organs in new light: the fate of neuroendocrine photoreceptors. Phil. Trans. R. Soc. Lond., v. 358, p. 1679-1700, 2003.

GARCIA, R. A. P.; AFECHE, S. C.; SCIALFA, J. H.; AMARAL, F. G.; SANTOS, S. H. J.; LIMA, F. B.; YOUNG, M. E.; CIPOLLA-NETO, J. Insulin modulates norepinephrine-mediated melatonin synthesis in cultured rat pineal gland. Life Sci., v. 82, p. 108-114, 2008.

GARCIA, R. A. P.; MARÇAL, A. C.; ANDRADE, J. S.; CARMO-BUONFIGLIO, D.; AMARAL, F. G.; AFECHE, S. C.; CIPOLLA-NETO, J.; CARVALHO, C. R. O. Insulin temporal sensitivity and its signaling pathway in the rat pineal gland. Life Sci., v. 87, p. 169-174, 2010.

GREEN, C. B.; TAKAHASHI, J. S.; BASS, J. The Meter of Metabolism. Cell, v. 134, p. 728742, 2008.

HALL, J. E. Insulina, glucagon e Diabetes mellitus. In: médica. Rio de Janeiro: Elsevier, 2011. p. 987-999.

\section{Tratado de fisiologia}

HERICHOVÁ, I.; ZEMAN, M.; STEBELOVÁ, K.; RAVINGEROVÁ, T. Effect of streptozotocininduced diabetes on daily expression of per2 and $\mathrm{dbp}$ in the heart and liver and melatonin rhythm in the pineal gland of Wistar rat. Mol. Cell. Biochem., v. 270, p. 223-229, 2005.

HARDELAND, R.; CARDINALI, D. P.; SRINIVASAN, V.; SPENCE, D. W.; BROWN, G. M.; PANDI-PERUMAL, S. R. Melatonin: A pleiotropic, orchestrating regulator molecule. Progress in Neurobiology, v. 93, p. 350-384, 2011.

HUANG, Z.; LIU, T.; CHATTORAJ, A.; AHMED, S.; WANG, M. M.; DENG, J.; SUN, X.; BORJIGIN, J. Posttranslational regulation of TPH1 is responsible for the nightly surge of 5HT output in the rat pineal gland. J. Pineal Res., v. 45, p. 506-514, 2008.

INTERNATIONAL DIABETES FEDERATION. Diabetes atlas. 5. ed. Disponível em: <http://www.idf.org/diabetesatlas/news/fifth-edition-release>. Acesso em: 25 jun. 2012.

KIM, J-SO; BAILEY, M. J.; HO, A. K.; MOLLER, M.; GAILDRAT, P.; KLEIN, D. C. Daily rhythm in pineal phosphodiesterase (PDE) activity reflects adrenergic/3'-5'-cyclic adenosine 5'-monophosphate induction of the PDE4B2 variant. Endocrinology, v. 148, n. 4, p. 14751485, 2007.

KLEIN, D. C.; BERG, G. R.; WELLER, J. Melatonin synthesis: adenosine 3',5'monophosphate and norepinephrine stimulate N-acetyltransferase. Science, v. 168, n. 934, p. 979-980, 1970.

KLEIN, D. C.; WELLER, J. L. Indole metabolism in the pineal gland: a circadian rhythm in Nacetyltransferase. Science, v. 169, n. 950, p. 1093-1095, 1970.

KLEIN, D. C.; BUDA, M. J.; KAPOOR, C. L.; KRISHNA, G. Pineal serotonin Nacetyltransferase activity: abrupt decrease in adenosine 3',5'-monophosphate may be signal for "Turnoff". Science, v. 199, p. 309-311, 1978.

KLEIN, D. C.; SUGDEN, D.; WELLER, J. L. Postsynaptic a-adrenergic receptors potentiate the $\beta$-adrenergic stimulation of pineal serotonin $\mathrm{N}$-acetyltransferase. Proc. Natl. Acad. Sci. USA, v. 80, p. 599-603, 1983.

$\mathrm{KOCH}, \quad$ M.; MAUHIN, V.; STEHLE, J. H.; SCHOMERUS, C.; KORF, H. W. Desphosphorylation of pCREB by protein serine/threonine phosphatase is involved in 
inactivation of NAT gene transcription in rat pineal gland. J. Neurochem., v. 85, p. 170-179, 2003.

KORKMAZ, A.; MA, S.; TOPAL, T.; ROSALES-CORRAL, S.; TAN, D.X.; REITER, R.J. Glucose: A vital toxin and the potential utility of melatonin in protecting against the diabetic state. Mol. Cell. Endocrinol., v. 349, p. 75-82, 2012.

LENZEN, S. The mechanisms of alloxan- and streptozotocin-induced diabetes. Diabetologia, v. 51, p. 216-226, 2008.

LERNER, A. B. et al. Isolation of melatonin, the pineal gland factor that lightens melanocytes. J. Am. Chem. Soc., v. 80, p. 2587, 1958.

LIMA, F. B.; MATSUSHITA, D. H.; HELL, N. S.; DOLNIKOFF, M. S.; OKAMOTO, M. M.; CIPOLLA- NETO, J. The regulation of insulin action in isolated adipocytes. Role of the periodicity of food intake, time of the day and melatonin. Braz. J. Med. Biol. Res., p. 9951000, 1994.

LIMA, F. B.; MACHADO, U. F.; BARTOL, I.; SERAPHIM, P. M.; SUMIDA, D. H.; MORAES, S. M. F.; HELL, N. S.; OKAMOTO, M. N. O.; SAAD, M. J.; CARVALHO, C. R. O.; CIPOLLANETO, J. Pinealectomy causes glucose intolerance and decreases adipose cell responsiveness to insulin in rats. Am. J. Physiol., v. 275, p. E934- E941, 1998.

LIMA, L. M. B.; REIS, L. C.; LIMA, M. A. Influence of the pineal gland on the physiology, morphometry and morphology of pancreatic islets in rats. Rev. Bras. Biol., São Carlos, v. 61 , n. 2, p. 333-340, 2001.

LUCHETTI, F.; CANONICO, B.; BETTI, M.; ARCANGELETTI, M.; PILOLLI, F.; PIRODDI, M.; CANESI, L.; PAPA, S.; GALLI, F. Melatonin signaling and cell protection function. The FASEB Journal, v. 24, p. 3603-3624, 2010.

MAILLET, F.; FERRY, G.; VELLA, F.; BERGER, S.; COGÉ, F.; CHOMARAT, P.; MALLET, C.; GUÉNIN, S. P.; GUILLAUMET, G.; VIAUD-MASSAURD, M. C.; YOUS, S.; DELAGRANGE, P.; BOUTIN, J. A. Characterization of the melatoninergic MT3 binding site on the NRH:quinone oxidoreductase 2 enzyme. Bioche. Pharmacol., v. 71, p. 74-88, 2005.

MANTELE, S.; OTWAY, D. T.; MIDDLETON, D.; BRETSCHNEIDER, S.; WRIGHT, J.; ROBERTSON, M. D.; SKENE, D. J.; JOHNSTON, J. D. Daily plasma rhythms of plasma melatonin, but not plasma leptin or leptin mRNA, vary between lean, obese and type 2 diabetic men. PLos One, v. 7, p. 1-8, 2012.

MARONDE, E. E.; WICHT, H.; TASKÉN, K.; GENIESSER, H. G.; DEGHANI, F.; OLCESE, J.; KOLF, H. W. CREB phosphorylation and melatonin biosynthesis in the rat pineal: involvement of cyclic AMP dependent protein kinase Type II. J. Pineal Res., v. 27, p. 170182, 1999.

MARZZOCO, A.; TORRES, B. B. Regulação integrada do metabolismo. In:

Bioquímica básica. Rio de Janeiro: Guanabara Koogan, 2007. p. 304-314.

MONTILLA, P. L.; VARGAS, J. F.; TÚNEZ, I. F.; de AGUEDA, M. C. M.; VALDELVIRA, M. E. D.; CABRERA, E. S. Oxidative stress in diabetic rats induced by streptozotocin: protective effects of melatonin. J. Pineal Res., v. 25, p. 94-100, 1998.

MORGAN, P.; BARRET, P.; HOWELL, H.; HELLIWEL, R. Melatonin receptors: localization, molecular pharmacology and physiological significance. Neurochem. Int., v. 24, p. 101-146, 1994. 
O'BRIEN, I.A.; LEWIN, I. G.; O'HARE, J. P. et al. Abnormal circadian rhythm of melatonin in diabetic autonomic neuropathy. Clin. Endocrinol., v. 24, p. 359-364, 1986.

PARFITT, A.; WELLER, J. L.; KLEIN, D. C. Beta adrenergic-blockers decrease adrenergically stimulated $\mathrm{N}$-acetyltransferase activity in pineal glands in organ culture. Neuropharmacology, v. 15, p. 353-358, 1976.

PARK, H. T.; KIM, Y. J.; YOON, S.; KIM, J. B.; KIM, J. J. Distributional characteristics of the mRNA for retinoid $Z$ receptor $B$ (RZRB), a putative nuclear melatonin receptor, in the rat brain and spinal cord. Brain Res., v. 747, p. 332-337. 1997.

PESCHKE, E.; FRESE, T.; CHANKIEWITZ, E.; PESCHKE, D.; PREISS, U.; SCHNEYER, U.; SPESSERT, R.; MÜHLBAUER, E. Diabetic Goto-Kakizaki rats as well as type 2 diabetic patients show a decreased diurnal serum melatonin level and an increased pancreatic melatonin-receptor status. J. Pineal Res., v. 40, p. 135-143, 2006.

PESCHKE, E.; WOLGAST, S.; BAZWINSKY, I.; PÖNICKE, K.; MÜHLBAUER, E. Increased melatonin synthesis in pineal glands of rats in streptozotocin induced type 1 diabetes. J. Pineal Res., v. 45, p. 439-448, 2008.

PESCHKE, E.; HOFMANN, K.; PÖNICK, K.; WEDEKING, D., MÜHLBAUER, E. Catecholamines are the key for explaining the biological relevance of insulin-melatonin antagonisms in type 1 and type 2 diabetes. J. Pineal. Res. v. 52, p.389-396, 2012.

PICINATO, M. C.; HABER, E. P.; CIPOLLA-NETO, J.; CURI, R.; CARVALHO, C.R.O.; CARPINELLI, A.R. Melatonin inhibits insulin secretion and drecreases PKA levels without interfering with glucose metabolism in rat pancreatic islets. J. Pineal Res., v. 33, p. 156-160, 2002a.

PICINATO, M. C.; HABER, E. P.; CARPINELLI, A. R.; CIPOLLA-NETO, J. Daily rhythm of glucose-induced insulin secretion by isolated islets from intact and pinealectomized rat. $\mathbf{J}$. Pineal Res., v. 33, p. 172-177, $2002 b$.

PICINATO, M. C.; HIRATA, A. E.; CIPOLLA-NETO, J.; CURI, R.; CARVALHO, C. R. O.; ANHÊ, G. F.; CARPINELLI, A. R. Activation of insulin and IGF-1 signaling pathways by melatonin through MT1 receptor in isolated rat pancreatic islets. J. Pineal Res., v. 44, n. 1, p.88-94, 2008.

REITER, R. J. The melatonin rhythm: both a clock and a calendar. Experientia, v. 49, p. 654-664, 1993.

REITER, R. J.; TAN, D. X.; GITTO, E.; SAINZ, R. M.; MAYO, J. C.; LEON, J.; MANCHESTER, L. C.; VIJAYALAXMI; KILIC, E.; KILIC, U. Pharmacological utility of melatonin in reducing oxidative cellular and molecular damage. Pol. J. Pharmacol., v. 56, n. 2, p. 159-170, 2004.

REPPERT, S. M.; GODSON, C.; MAHLE, C. D.; WEAVER, D. R.; SLAUGENHAUPT, S. A.; GUSELLA, J. F. Molecular characterization of a second melatonin receptor expressed in human retina and brain: The Mel1b melatonin receptor. Proc. Natl. Acad. Sci. USA, v. 92, p. 8734-38, 1995.

RIBELAYGA, C.; PÉVET, P.; SIMMONEAUX, V. Adrenergic and peptidergic regulations of hydroxyindole-O-methyltransferase activity in rat pineal gland. Brain Res., v. 777, p. 247250, 1997. 
RIBELAYGA, C.; GAUER, F.; CALGARI, C.; PEVET, P.; SIMONNEAUX, V. Photoneural regulation of rat pineal hydroxyindole-O-methyltransferase (HIOMT) messenger ribonucleic acid expression: an analysis of its complex relationship with HIOMT activity. Endocrinology, v. 140, p. $1375-1384,1999 a$.

RIBELAYGA, C.; GARIDOU, M-L.; MALAN, A.; GAUER, F.; CALGARI, C.; PÉVET, P.; SIMONNEAUX, V. Photoperiodic control of the rat pineal AANAT and HIOMT gene expression and its effect on melatonin synthesis. J. Biol. Rhythms, v. 14, n. 2, p. 105-115, 1999b.

RIOS, E. R. V.; VENÂNCIO, E. T.; ROCHA, N. F. M.; WOODS, D. J.; VASCONCELOS, S.; MACEDO, D.; SOUSA, C. F.; FONTELES, M. M. F. Melatonin: Pharmacological aspects and clinical trends. Int. J. Neurosci., v. 120, p. 583-590, 2010.

ROBEVA, R.; KIRILOV, G.; TOMOVA, A.; KUMANOV, P. Low testosterone levels and unimpaired melatonin secretion in young males with metabolic syndrome. Andrologia, v. 38 p. 216-220, 2006.

ROSEBOOM, P. H.; COON, S. L.; BALER, R.; McCUNE, S. K.; WELLER, J. L.; KLEIN, D. C. Melatonin synthesis: analysis of the more than 150-fold nocturnal increase in serotonin $\mathrm{N}$ acetyltransferase messenger ribonucleic acid in the rat pineal gland. Endocrinology, v. 137, n. 7, p. 3033-3044, 1996.

SERAPHIM, P. M.; BARTOL, I.; CIPOLLA-NETO, J.; MACHADO, U. F. Quantification of GLUT 4 transporters in insulin- sensitive tissues from pinealectomized rats. In: WEBB, S.; PUIG-DOMINGO, M.; MOLLER, M.; PÉVET, P. Pineal Uptade: from molecular biology to clinical implications. New York: PJD Publications Limited, 1997. p. 99-106.

SEMRA, Y. K.; SMITH, N. C. E.; LINCOLN, J. Comparative effects of high glucose on different adult sympathetic neurons in culture. Neuroreport, v. 15, p. 2321-2325, 2004.

SCHMIDT, R. E. Neuronal preservation in the sympathetic ganglia of rats with chronic streptozotocin-induced diabetes. Brain. Res., v. 921, p. 256-259, 2001.

SHI, Q.; SENG, J.; DONG, Y.; XU, K. Y. Concurrent impairment of $\left(\mathrm{Na}^{+}+\mathrm{K}^{+}\right)$-ATPase activity in multi-organ of type-1 diabetic NOD mice. J. Diabet. Complications. Dezembro/2012. IN PRESS.

SIMONNEAUX, V.; RIBELAYGA, C. Generation of the melatonin endocrine message in mammals: a review of the complex regulation of melatonin synthesis by norepinephrine, peptides, and other pineal transmitters. Pharmacol. Rev., v. 55, p. 325-395, 2003.

SKORUPA, A. L.; GARIDOU, M. L.; BOTHOREL, B.; SABOUREAU, M.; PÉVET, P. ; CIPOLLA-NETO, J.; SIMONNEAUX, V. Pineal melatonin synthesis and release are not altered throughout the estrous cycle in female rats. J. Pineal Res., v. 34, p. 53-59, 2003.

SLOMINSKI, R. M.; REITER, R. J.; SCHLABRITZ-LOUTSEVITCH, N.; OSTROM, R. S.; SLOMINSKI, A. T. Melatonin membrane receptors in peripheral tissues: Distribution and functions. Mol. Cell. Endocrinol., v. 2, p. 156-166, 2012.

STEBELOVÁ, K.; HERICHOVÁ, I.; ZEMAN, M. Diabetes induces changes in melatonin concentrations in peripheral tissues of rat. Neuro Endocrinol. Lett., v. 28, n. 2, p. 159-165, 2007. 
SUDNOKOVICH, E. J.; MAKSIMCHIK, Y. Z.; ZABRODSKAYA, S. V.; KUBYSHIN, V. L.; LAPSHINA, E. A.; BRYSZEWSKA, M.; REITER, R. J.; ZAVODNIK, I. B. Melatonin attenuates metabolic disorders due to streptozotocin-induced diabetes in rats. Eur. J. Pharmacol., v. 569, p. 180-187, 2007.

SUGDEN, D.; VANECEK, J.; KLEIN, D. C.; THOMAS, T. P.; ANDERSON, W. B. Activation of protein kinase $C$ potentiates isoprenaline-induced cyclic AMP accumulation in rat pinealocytes. Nature, v. 314, p. 359-361, 1985.

SUGDEN, A. L.; SUGDEN, D.; KLEIN, D. C. Essential role of calcium influx in the adrenergic regulation of CAMP and cGMP in rat pinealocytes. J. Biol. Chem., v. 261, p. 11608-11612, 1986.

SUGDEN, A. L.; SUGDEN, D.; KLEIN, D. C. a1-Adrenoceptor activation elevates cytosolic calcium in rat pinealocytes by increasing net influx. J. Biol. Chem., v. 262, p. 741-745, 1987.

TSAI, M. H.; WEI, I. H.; JIANG-SHIEH, Y. F.; JOU, M. J.; KO, M. H.; CHEN, H. M.; WU, C. H. Expression of protein gene product 9.5, tyrosine hydroxylase and serotonin in the pineal gland of rats with streptozotocin-induced diabetes. Neurosci. Res., v. 60, p. 233-243, 2008.

TZAVARA, E. T.; POUILLE, Y.; DEFER, N.; HANOUNE, J. Diurnal variation of the adenylyl cyclase type 1 in the rat pineal gland. Proc. Natl. Acad. Sci., v. 93, p. 11208-11212, 1996.

TURJANSKI, A. G.; ESTRIN, D. A.; ROSENSTEIN, R. E.; MCCORMICK, J. E.; MARTIN, S. R.; PASTORE, A. BIEKOFSKY, R. R.; MARTORANA, V. NMR and molecular dynamics studies of the interaction of melatonin with calmodulin. Prot. Sci., v. 13, p. 2925-2938, 2004.

TUTUNCU, N. B.; BATUR, M. K.; YILDIRIR, A.; TUTUNCU, T.; DEGER, A.; KORAY, Z.; ERBAS, B.; KABAKCI, G.; AKSOYEK, S.; ERBAS, T. Melatonin levels decrease in type 2 diabetic patients with cardiac autonomic neuropathy. J. Pineal Res., v. 39, n. 1, p. 43-49, 2005.

VANECEK, J.; SUGDEN, D.; WELLER, J. L.; KLEIN, D. C. Atypical synergistic $\alpha 1-$ and $\beta-$ adrenergic regulation of adenosine 3',5'-monophosphate and guanosine 3',5'monophosphate in rat pinealocytes. Endocrinology, v. 116, p. 2167-2173, 1985.

VER, A.; SZANTO, I.; BANYASZ T.; CSERMELY P.; VEGH, E.; SOMOGYI J. Changes in the expression of $\mathrm{Na}+\mathrm{K}+$ ATPase isoenzymes in the left ventricle of diabetic rat hearts: effect of insulin treatment. Diabetologia, v. 40, p. 1255-1262, 1997.

VOLLRATH, L. The pineal organ. In: OKSCHE, A.; VOLLRATH, L. Handbuch Der mikroskopischen anatomie des menschen. Berlin: Springer, 1981. v. 6/7.

VURAL, H.; SABUNCU, T.; ARSLAN, S. O.; AKSOY, N. Melatonin inhibits lipid peroxidation and stimulates the antioxidant status of diabetic rats. J. Pineal Res., v. 31, n. 3, p. 193-198, 2001.

YU, L.; SCHAAD, N. C.; KLEIN, D. C. Calcium potentiates cyclic AMP stimulation of pineal arylalkylamine N-acetyltransferase. J. Neurochem., v. 60, p. 1436-1443, 1993.

ZANQUETTA, M. M.; SERAPHIM, P. M.; SUMIDA, D. H.; CIPOLLA-NETO, J.; MACHADO, U. F. Calorie restriction reduces pinealectomy-induced insulin resistance by improving GLUT4 gene expression and its translocation to the plasma membrane. J. Pineal Res., v. 35, p. $141-148,2003$. 